\title{
EVALUASI TINGKAT KENYAMANAN DAN ESTETIKA TAMAN KOTA BSD CITY TANGERANG SELATAN
}

RANI ISNANIYAH

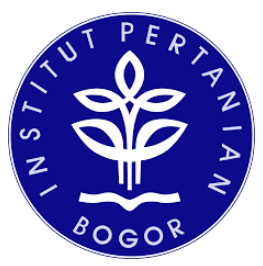

DEPARTEMEN ARSITEKTUR LANSKAP

FAKULTAS PERTANIAN INSTITUT PERTANIAN BOGOR

BOGOR 2021 



\section{PERNYATAAN MENGENAI SKRIPSI DAN SUMBER INFORMASI SERTA PELIMPAHAN HAK CIPTA}

Dengan ini saya menyatakan bahwa skripsi dengan judul "Evaluasi Tingkat Kenyamanan dan Estetika Taman Kota BSD City Tangerang Selatan" adalah karya saya dengan arahan dari dosen pembimbing dan belum diajukan dalam bentuk apapun kepada perguruan tinggi manapun. Sumber informasi yang berasal atau dikutip dari karya yang diterbitkan maupun tidak diterbitkan dari penulis lain telah disebutkan dalam teks dan dicantumkan dalam Daftar Pustaka di bagian akhir skripsi ini.

Dengan ini saya melimpahkan hak cipta dari karya tulis saya kepada Institut Pertanian Bogor.

Bogor, Februari 2021

Rani Isnaniyah 



\section{ABSTRAK \\ RANI ISNANIYAH. Evaluasi Tingkat Kenyamanan dan Estetika Taman Kota BSD City Tangerang Selatan. Dibimbing oleh TATI BUDIARTI.}

Perkembangan kota mendorong terbentuknya kota-kota baru di sekitar kotakota besar sebagai tempat tinggal alternatif yang disebut kota mandiri. Kawasan Bumi Serpong Damai (BSD) City adalah kota mandiri yang terletak di Kota Tangerang Selatan, Banten. Kawasan BSD City berbatasan langsung dengan DKI Jakarta, menjadikannya sebagai tempat alternatif bagi masyarakat DKI Jakarta yang telah sangat meningkat. BSD City adalah kota baru dengan konsep permukiman ramah lingkungan yang memiliki ruang terbuka hijau (RTH) untuk menciptakan lingkungan perkotaan yang indah. RTH yang tersedia di kawasan BSD City ada yang berupa taman kota yaitu Taman Kota 1 BSD dan Taman Kota 2 BSD. Penelitian ini dilakukan di Taman Kota 1 BSD dan Taman Kota 2 BSD dengan tujuan yaitu mengidentifikasi jenis dan fungsi tanaman, mengevaluasi fungsi ekologis dan estetika RTH, dan memberikan hasil berupa rekomendasi perbaikan serta penataan tanaman untuk meningkatkan kenyamanan dan estetika taman. Hasil penelitian menunjukkan jumlah pohon pada Taman Kota 2 BSD lebih banyak dibandingkan Taman Kota 1 BSD, sedangkan jumlah spesiesnya lebih beragam pada Taman Kota 1 BSD. Hasil penilaian berdasarkan fungsi tanaman dalam modifikasi suhu dan kontrol kelembaban pada Taman Kota 1 BSD dan Taman Kota 2 BSD termasuk kategori baik. Berdasarkan fungsi penahan angin pada Taman Kota 1 BSD juga termasuk kategori baik, sedangkan Taman Kota 2 BSD berkategori sedang. Hasil pengukuran juga menunjukkan kedua taman tersebut efektif dalam ameliorasi iklim mikro apabila dibandingkan dengan suhu rata-rata dan kelembaban rata-rata di luar taman. Penilaian estetika menunjukkan Taman Kota 1 BSD dan Taman Kota 2 BSD masuk dalam kategori estetika tinggi. Responden juga sebagian besar sudah merasa puas dengan kondisi kedua taman kota tersebut saat ini tapi menyarankan agar adanya perbaikan fasilitas yang telah rusak. Responden juga menyarankan penambahan tanaman yang lebih bervariasi seperti tanaman berbunga untuk menambah nilai estetika taman.

Kata kunci: tingkat kenyamanan, ruang terbuka hijau, taman kota, BSD City 



\begin{abstract}
RANI ISNANIYAH. Evaluation of Comfort Valeu and Aesthetics Level of BSD City Park South Tangerang. Supervised by TATI BUDIARTI.

The development of cities encourages the formation of new cities around big cities as alternative living areas, which are called independent cities. Bumi Serpong Damai (BSD) City area is an independent city located in South Tangerang City, Banten. It is directly adjacent to DKI Jakarta, making it an alternative area for DKI Jakarta residents who have greatly improved. BSD City is a new city with an eco-friendly residential concept that has green open space to create a beautiful urban environment. The green open spaces in the BSD City area are in the form of city parks, namely Taman Kota 1 BSD and Taman Kota 2 BSD. This research was conducted in Taman Kota 1 BSD and Taman Kota 2 BSD with an aim of identifying the plants' types and functions, evaluating the ecological and aesthetic functions of the green open spaces, and providing results in the form of recommendations for plants improvement and arrangement to improve the parks' comfort and aesthetics. The results showed that the number of plants in Taman Kota 2 BSD was higher than Taman Kota 1 BSD, while the more diverse species were in Taman Kota 1 BSD. The results of the assessment based on plant function in temperature modification and humidity control in Taman Kota 1 BSD and Taman Kota 2 BSD were in the good category. Based on the windbreak function, Taman Kota 1 BSD was in the good category, while Taman Kota 2 BSD was in the moderate category. The measurement results also showed that the two parks were effective in ameliorating the microclimate when compared to the average temperature and average humidity outside the parks. The aesthetic assessment showed that Taman Kota 1 BSD and Taman Kota 2 BSD were in the high aesthetic category. Most respondents were also satisfied with the current condition of the city parks but suggested that the broken facilities should be repaired. Respondents also suggested to add more varied plants such as flowering plants to add the aesthetic value to the parks.
\end{abstract}

Keywords: comfort value, green open space, city park, BSD City 

(C) Hak Cipta Milik IPB, tahun 2021

Hak Cipta dilindungi Undang-Undang

Dilarang mengutip sebagian atau seluruh karya tulis ini tanpa mencantumkan atau menyebutkan sumbernya. Pengutipan hanya untuk kepentingan pendidikan, penelitian, penulisan karya ilmiah, penyusunan laporan, penulisan kritik, atau tinjauan suatu masalah, dan pengutipan tersebut tidak merugikan kepentingan $I P B$.

Dilarang mengumumkan dan memperbanyak sebagian atau seluruh karya tulis ini dalam bentuk apa pun tanpa izin IPB. 



\title{
EVALUASI TINGKAT KENYAMANAN DAN ESTETIKA TAMAN KOTA BSD CITY TANGERANG SELATAN
}

\section{RANI ISNANIYAH}

\author{
Skripsi \\ sebagai salah satu syarat untuk memperoleh gelar \\ Sarjana Arsitektur Lanskap \\ pada \\ Departemen Arsitektur Lanskap
}

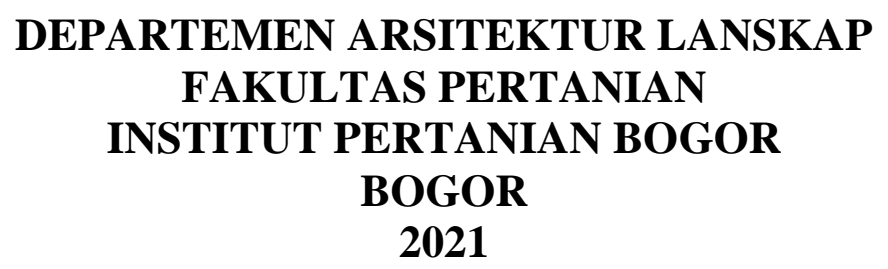





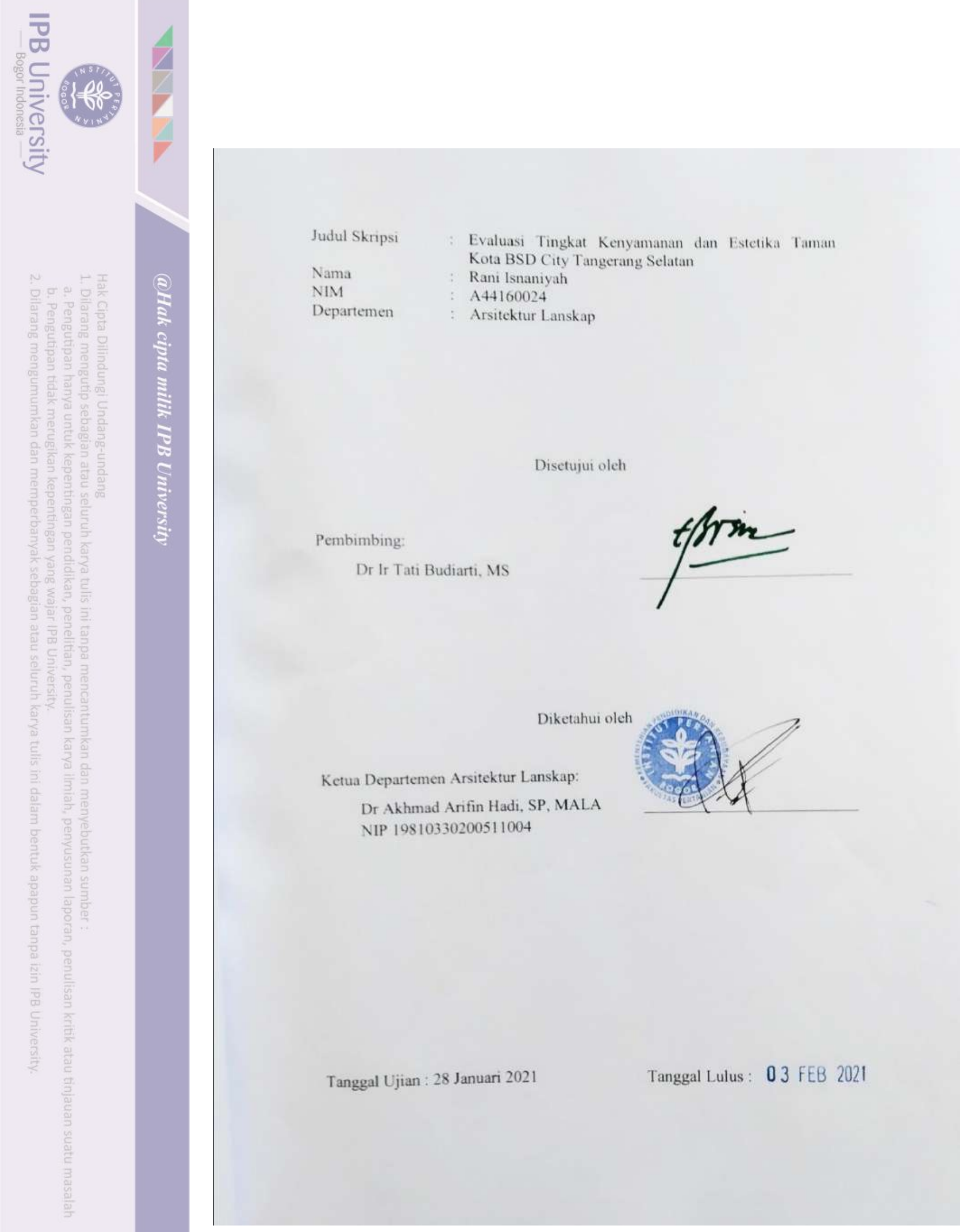





\section{PRAKATA}

Puji syukur penulis panjatkan kehadirat Allah subhanahu wa ta'ala karena atas limpahan rahmat, karunia, dan atas izin-Nya sehingga karya ilmiah yang berjudul "Evaluasi Tingkat Kenyamanan dan Estetika Taman Kota BSD City Tangerang Selatan" ini dapat diselesaikan dengan baik. Penulis menyampaikan terima kasih kepada

1. Kedua orang tua yaitu (Alm) Bapak Riyadi dan Ibu Siti Nuryani, serta kakak Rini Apriani yang telah memberikan dukungan, doa, dan bantuan terbesar kepada penulis dengan penuh kasih sayang;

2. Dr Ir Tati Budiarti, MS selaku pembimbing yang telah memberikan banyak ilmu, saran, dukungan, dan kesediaan waktunya kepada penulis sehingga penulis dapat melaksanakan dan menyelesaikan penelitian ini;

3. Sahabat di kontrakan Al Mahabbah yaitu Nilma Agusti, Raudhatul Fitri, dan Rismawati yang telah menemani, mendukung, dan membantu penulis hingga proses penulisan dan ujian skripsi;

4. Teman seperbimbingan yaitu Adrianti, Vira, dan Maya yang telah saling membantu dan mendoakan;

5. Seluruh teman Departemen Arsitektur Lanskap yang telah menemani di masa perkuliahan dan membantu penulis selama penelitian hingga proses penulisan skripsi;

6. Seluruh dosen Departemen Arsitektur Lanskap atas segala ilmu bermanfaat yang telah diberikan serta seluruh tenaga pendidikan dan staff Departemen Arsitektur Lanskap khususnya Mas Fauzi dan Mas Rahmat yang telah banyak membantu segala urusan administrasi;

7. Sahabat terdekat penulis yaitu Lasmi Wahyuni yang tidak bosannya mengajak penulis pada kebaikan, menghibur, memberi semangat, dan dukungan lainnya untuk penulis;

8. Seluruh responden yang telah membantu melengkapi keperluan data penelitian penulis;

9. Sahabat dakwah, keluarga FKRD Faperta, Kakak Murabbiyah, kawan mentoring, dan orang baik lainnya yang telah membantu serta memberikan doa-doa terbaik untuk penulis;

10. Dinas Lingkungan Hidup dan Dinas Pekerjaan Umum Kota Tangerang Selatan yang telah memberikan izin penelitian dan membantu beberapa kelengkapan data sekunder yang dibutuhkan untuk penelitian.

Bogor, Februari 2021

Rani Isnaniyah 



\section{DAFTAR ISI}

DAFTAR TABEL $\quad x$

DAFTAR GAMBAR $\quad x$

DAFTAR LAMPIRAN $\quad$ xii

PENDAHULUAN 1

Latar Belakang $\quad 2$

Tujuan Penelitian $\quad 2$

Manfaat Penelitian $\quad 2$

Kerangka Pikir Penelitian $\quad 3$

TINJAUAN PUSTAKA 4

Taman Kota sebagai Ruang Terbuka Hijau 4

Fungsi Ruang Terbuka Hijau sebagai Ameliorasi Iklim 4

Estetika $\quad 5$

Scenic Beauty Estimation (SBE) 6

Persepsi dan Preferensi Masyarakat 6

Evaluasi 6

METODOLOGI

Lokasi dan Waktu Penelitian $\quad 7$

Alat dan Bahan $\quad 7$

Metode Penelitian $\quad 8$

HASIL DAN PEMBAHASAN 17

Kondisi Umum 17

Letak, Luas, dan Batas Tapak $\quad 17$

$\begin{array}{ll}\text { Topografi } & 18\end{array}$

$\begin{array}{ll}\text { Iklim } & 18\end{array}$

Aksesibilitas dan Sirkulasi $\quad 19$

Fasilitas dan Objek $\quad 19$

Identifikasi Jenis dan Fungsi Tanaman $\quad 22$

Evaluasi Fungsi Ekologis Tanaman $\quad 25$

Fungsi Modifikasi Suhu $\quad 25$

Fungsi Kontrol Kelembaban Udara 31

Fungsi Penahan Angin $\quad 37$

Evaluasi Kualitas Estetika $\quad 43$

Persepsi dan Preferensi Responden $\quad 49$

Rekomendasi $\quad 53$

SIMPULAN DAN SARAN

Simpulan $\quad 57$

Saran $\quad 58$

DAFTAR PUSTAKA $\quad 58$

LAMPIRAN $\quad 61$

$\begin{array}{ll}\text { DAFTAR RIWAYAT HIDUP } & 78\end{array}$ 


\section{DAFTAR TABEL}

1 Kriteria fungsi penanaman pohon 9

2 Kriteria penilaian fungsi ekologis tanaman 14

3 Data iklim rata-rata Kota Tangerang Selatan tahun $2020 \quad 19$

4 Jenis dan fungsi pohon di Taman Koa 1 BSD 22

5 Jenis dan fungsi pohon di Taman Kota 2 BSD 24

6 Penilaian aspek fungsi modifikasi suhu di Taman Kota 1 BSD 25

7 Hasil pengukuran suhu udara di Taman Kota 1 BSD 27

8 Penilaian aspek fungsi modifikasi suhu di Taman Kota 2 BSD 27

9 Hasil pengukuran suhu udara di Taman Kota 2 BSD 29

10 Persentase penilaian tanaman fungsi modifikasi suhu 30

11 Rata-rata suhu udara Taman Kota 1 BSD dan Taman Kota 2 BSD 30

12 Penilaian aspek fungsi kontrol kelembaban udara di 32

Taman Kota 1 BSD

13 Hasil pengukuran kelembaban di Taman Kota 1 BSD 33

14 Penilaian aspek fungsi kelembaban di Taman Kota 2 BSD 34

15 Hasil pengukuran kelembaban di Taman Kota 2 BSD 35

16 Persentase penilaian tanaman fungsi kontrol kelembaban 36

17 Rata-rata kelembaban Taman Kota 1 BSD dan Taman Kota 2 BSD 36

18 Penilaian aspek fungsi penahan angin di Taman Kota 1 BSD 38

19 Penilaian aspek fungsi penahan angin di Taman Kota 2 BSD 40

20 Persentase penilaian tanaman fungsi penahan angin 42

21 Penilaian THI di Taman Kota 1 BSD dan Taman Kota 2 BSD 43

22 Penilaian kualitas estetika SBE Taman Kota 1 BSD 43

23 Penilaian kualitas estetika SBE Taman Kota 2 BSD 46

\section{DAFTAR GAMBAR}

1 Kerangka pikir penelitian 3

2 Lokasi penelitian $\quad 7$

3 Tahapan penelitian $\quad 8$

4 Sketsa jarak tanam antarpohon rapat $\quad 10$

5 Sketsa jarak tanam antarpohon rapat $\quad 10$

6 Titik pengukuran suhu Taman Kota 1 BSD 11

7 Titik Pengukuran Suhu Taman Kota 2 BSD 12

8 Letak dan Batas Tapak Taman Kota 1 BSD 17

9 Letak dan Batas Tapak Taman Kota 2 BSD 18

10 Fasilitas dan objek pada Taman Kota 1 BSD 20

11 Fasilitas dan objek pada Taman Kota 2 BSD 21

12 Kategori penilaian tanaman Taman Kota 1 BSD dalam fungsi 26 modifikasi suhu

13 Kategori penilaian tanaman Taman Kota 2 BSD dalam fungsi 29 modifikasi suhu

14 Persentase persepsi responden tentang tingkat suhu 30

15 Persentase persepsi responden tentang lokasi yang sejuk 31

16 Lokasi yang sejuk 32 
17 Kategori penilaian tanaman Taman Kota 1 BSD terhadap aspek fungsi kontrol kelembaban

18 Kategori penilaian tanaman Taman Kota 2 BSD terhadap aspek fungsi kontrol kelembaban

19 Persentase persepsi responden tentang tingkat kelembaban

20 Persentase persepsi responden tentang lokasi yang lembab

21 Lokasi yang lembab

22 Kategori penilaian tanaman di Taman Kota 1 BSD terhadap aspek fungsi penahan angin

23 Persentase persepsi responden tentang tingkat kecepatan angin di Taman Kota 1 BSD

24 Persentase persepsi responden tentang lokasi yang terasa hembusan angin di Taman Kota 1 BSD

25 Kategori penilaian tanaman Taman Kota 2 BSD terhadap aspek fungsi penahan angin

26 Persentase persepsi responden tentang tingkat kecepatan angin di Taman Kota 2 BSD

27 Persentase persepsi responden tentang lokasi yang terasa hembusan angin di Taman Kota 2 BSD

28 Grafik nilai SBE Taman Kota 1 BSD

29 Persentase kualitas estetika Taman Kota 1 BSD

30 Foto Lanskap ke-4 (nilai SBE tertinggi) dan Lanskap 11 (nilai SBE terendah)

31 Titik Pengambilan Foto Lanskap Taman Kota 1 BSD

32 Grafik nilai SBE Taman Kota 2 BSD

33 Persentase kualitas estetika Taman Kota 2 BSD

34 Foto Lanskap ke-4 (nilai SBE tertinggi) dan Lanskap 11 (nilai SBE terendah)

35 Titik Pengambilan Foto Lanskap Taman Kota 2 BSD 48

36 Persentase jenis kelamin responden $\quad 49$

37 Persentase usia responden $\quad 49$

38 Persentase pendidikan terakhir responden $\quad 50$

39 Persentase pekerjaan responden $\quad 50$

40 Persentase tujuan responden berkunjung 50

41 Persepsi responden terhadap keindahan pemandangan 51

42 Persepsi responden terhadap keindahan penataan tanaman 51

43 Persepsi responden terhadap kebersihan $\quad 52$

44 Persepsi kepuasan terhadap $\quad 52$

45 Ilustrasi penataan tanaman Taman Kota 1 BSD 53

46 Ilustrasi penataan tanaman Taman Kota 2 BSD 54

47 Ilustrasi penambahan tanaman merambat pada tempat wudhu $\quad 55$ Mushala Taman Kota 1 BSD

48 Ilustrasi penambahan tanaman merambat pada tempat wudhu 55 Mushala Taman Kota 2 BSD

49 Ilustrasi perbaikan dan penataan pada gerbang Taman Kota 56 2 BSD

50 Contoh pemasangan papan nama tanaman 


\section{DAFTAR LAMPIRAN}

1 Kuesioner pengunjung Taman Kota 1 BSD

2 Kuesioner pengunjung Taman Kota 2 BSD 66

2 3 Kuesioner Scenic Beauty Estimatio 69

4 Foto lanskap Taman Kota 1 BSD 70

5 Foto lanskap Taman Kota 2 BSD $\quad 73$ 


\section{PENDAHULUAN}

\section{Latar Belakang}

Perkembangan kota senantiasa diikuti oleh arus urbanisasi. Selain semakin padat dan panas, daerah kota semakin tidak nyaman untuk tempat tinggal akibat penataan kota kurang terencana dengan baik. Kondisi ini memacu pertumbuhan kota-kota baru di sekitar kota besar sebagai tempat tinggal alternatif (Alhadi 2016). Kota baru yang memiliki fasilitas lengkap dan tertata dikenal dengan istilah kota mandiri. Kota mandiri menerapkan konsep permukiman yang terencana dengan baik, mulai dari bentuk bangunan, sistem jaringan utilitas maupun fasilitas-fasilitas yang ada di dalamnya. Selain itu, kota mandiri menawarkan kawasan hunian yang nyaman, memiliki fasilitas lengkap, tata lingkungan yang teratur, bersih dan jauh dari kebisingan. Namun pada perkembangan selanjutnya, tidak sedikit kota mandiri yang telah dibangun mengalami penurunan kualitas lingkungan (Wibisono 2008).

Migrasi penduduk dari kota besar ke kota mandiri menimbulkan perkembangan di kawasan kota mandiri tersebut. Perkembangan di kawasan kota tidak selalu berdampak positif. Pertumbuhan penduduk yang meningkat mengakibatkan bertambahnya kebutuhan masyarakat. Pembangunan beberapa fasilitas dilakukan untuk menunjang kebutuhan yang bertambah. Pembangunan tersebut mengunakan lahan yang sebelumnya merupakan ruang terbuka hijau sehingga mengakibatkan semakin berkurangnya ruang-ruang terbuka hijau di kota tersebut.

Ruang terbuka hijau (RTH) dalam lingkungan pembangunan secara global saat ini diperlukan demi menjaga keseimbangan kualitas lingkungan hidup suatu daerah. Ruang terbuka hijau (RTH) khususnya di wilayah perkotaan memiliki fungsi yang penting di antaranya terkait aspek ekologi, sosial budaya, dan estetika. Ruang terbuka hijau atau RTH yang ada di kawasan kota memiliki fungsi ekologis yang salah satunya yaitu sebagai ameliorasi iklim mikro yang dapat meningkatkan kenyamanan kota dengan mengontrol suhu, kelembaban, radiasi matahari, dan aliran angin (Grey dan Deneke 1978). Adapun dalam aspek sosial budaya, salah satu fungsi dari ruang terbuka hijau (RTH) di antaranya adalah sebagai ruang komunikasi dan interaksi sosial bagi masyarakat. Selain kedua aspek tersebut, RTH juga dapat berfungsi secara estetika diantaranya meningkatkan kenyamanan, memperindah lingkungan kota, serta menstimulasi kreativitas dan produktivitas warga kota (Imansari dan Khadiyanta 2015).

Masyarakat kota memiliki aktivitas mulai dari pagi hingga sore bahkan dari awal pekan hingga akhir pekan. Melakukan aktivitas yang sama setiap harinya tentu akan menimbulkan suatu kejenuhan. Masyarakat kota membutuhkan suatu lokasi yang berbeda dengan lingkungan tempat mereka bekerja untuk melakukan aktivitas di luar rutinitasnya. Keberadaan ruang publik di suatu kota bertujuan untuk menyediakan lokasi yang dapat digunakan oleh masyarakat kota untuk melakukan aktivitas sosial dengan nyaman (Kustianingrum 2013). RTH publik yang memberikan fungsi secara optimal dapat menjadi lokasi yang memberikan kenyamanan bagi masyarakat. 
Kawasan Bumi Serpong Damai (BSD) City merupakan salah satu kota mandiri yang terletak di Kota Tangerang Selatan, Banten. Kawasan BSD City yang luasnya 6.000 ha tidak hanya dibangun untuk pusat bisnis dan hunian saja, namun juga untuk kawasan hijau sebagai paru-paru kota yang sekaligus berfungsi sebagai tempat rekreasi. BSD City berbatasan langsung dengan DKI Jakarta, sehingga menjadi pilihan sebagai tempat tinggal alternatif bagi masyarakat yang sebelumnya tinggal di DKI Jakarta. Kawasan BSD City menjadi kota baru dengan konsep pemukiman ramah lingkungan yang memiliki ruang terbuka hijau (RTH) untuk menciptakan lingkungan perkotaan yang asri. RTH yang tersedia di kawasan BSD City di antaranya yaitu Taman Kota 1 BSD City dan Taman Kota 2 BSD City. Taman Kota 1 BSD City dan Taman Kota 2 BSD City merupakan RTH publik di kawasan BSD City yang memiliki area cukup luas dan sering dijadikan sebagai tempat rekreasi masyarakat. Kedua taman tersebut juga menjadi tempat rekreasi yang cukup terkenal di BSD City. Area yang cukup rindang menjadikan kedua RTH ini sebagai tempat favorit untuk beraktivitas di akhir pekan seperti olahraga, rekreasi, atau sekedar menjadi spot berfoto. Penelitian evaluasi tingkat kenyamanan dan estetika Taman Kota BSD City Tangerang Selatan perlu dilakukan untuk selanjutnya dapat menjadi pertimbangan agar fungsi RTH di kawasan BSD City yang merupakan kota mandiri dapat menjadi lebih optimal sehingga memberikan ruang yang nyaman kepada masyarakat.

\section{Tujuan Penelitian}

Penelitian mengenai evaluasi fungsi ekologis dan fungsi estetika di Ruang Terbuka Hijau BSD City Tangerang Selatan memiliki beberapa tujuan sebagai berikut:

1. mengidentifikasi vegetasi yang ada di Taman Kota 1 BSD City dan Taman Kota 2 BSD City beserta fungsinya,

2. mengkaji dan mengevaluasi tingkat kenyamanan dengan menganalisis fungsi vegetasi dalam modifikasi suhu, kontrol kelembaban udara, dan angin serta persepsi dan preferensi pengguna taman kota mengenai taman kota di kawasan BSD City Tangerang Selatan,

3. mengkaji dan mengevaluasi estetika Taman Kota 1 BSD City dan Taman Kota 2 BSD City,

4. menyusun rekomendasi tata hijau Taman Kota 1 BSD City dan Taman Kota 2 BSD City.

\section{Manfaat Penelitian}

Manfaat yang diperoleh dari hasil penelitian ini adalah sebagai berikut:

1. menambah pemahaman kepada pembaca mengenai fungsi tanaman terhadap tingkat kenyamanan Taman Kota 1 BSD City dan Taman Kota 2 BSD City,

2. memberikan masukan kepada Pemerintah Kota Tangerang Selatan dalam upaya penataan taman kota agar dapat memberi kenyamanan dan 
estetika yang optimal sehingga memberikan ruang yang nyaman untuk aktivitas masyarakat,

\section{Kerangka Pikir Penelitian}

Penelitian dilakukan dengan mengidentifikasi vegetasi yang ada serta menganalisis fungsi modifikasi suhu, kelembaban udara, dan aliran angin. Presepsi dan prefensi pengguna perlu diketahui sebagai pemberi masukan dalam penyusunan rekomendasi penataan vegetasi dan penilian kualitas visual/estetika. Kerangka pikir disusun dalam diagram alur (Gambar 1).

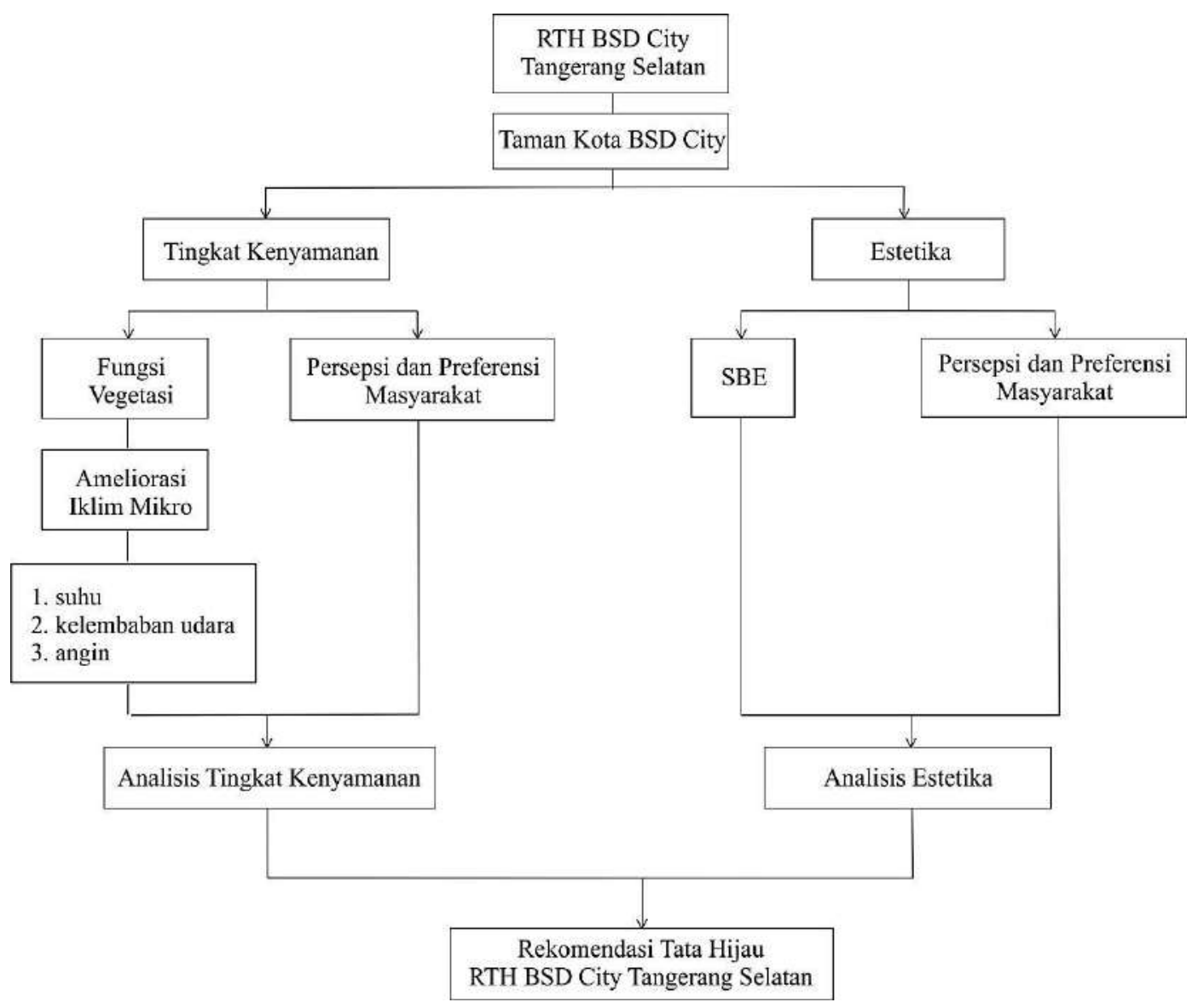

Gambar 1 Kerangka pikir penelitian 


\section{TINJAUAN PUSTAKA}

\section{Taman Kota sebagai Ruang Terbuka Hijau}

Definisi ruang terbuka hijau (RTH) yang mengacu pada Undang Undang Nomor 26 Tahun 2007 adalah area memanjang/jalur dan/atau mengelompok, yang penggunaannya lebih bersifat terbuka, tempat tumbuh tanaman, baik yang tumbuh secara alamiah maupun yang sengaja ditanam. Menurut Departemen PU (2008) RTH terbagi menjadi beberapa jenis sesuai dengan tipologinya. Secara fisik, RTH terbagi menjadi RTH alami dan RTH binaan. RTH alami biasanya berupa habitat fiar alami, kawasan lindung, dan taman nasional, sedangkan RTH binaan biasanya berupa taman, lapangan olahraga, pemakaman, dan jalur hijau jalan.

Berdasarkan Peraturan Menteri Dalam Negeri No. 1 Tahun 2007 Bab III Pasal 6, Taman kota merupakan salah satu bentuk ruang terbuka hijau kawasan perkotaan. Taman kota berdasarkan Permen PU No. 5 Tahun 2008 merupakan lahan terbuka yang berfungsi sosial dan estetik sebagai sarana kegiatan rekreasi, edukasi, atau kegiatan lain pada tingkat kota.

\section{Fungsi Ruang Terbuka Hijau sebagai Ameliorasi Iklim Mikro}

Pengatur iklim mikro atau ameliorasi iklim mikro merupakan salah satu fungsi ekologis RTH. RTH sebagai ameliorasi iklim mikro dapat menciptakan zona nyaman dengan mengatur empat elemen utama dalam ameliorasi iklim sesuai dengan komposisinya. Empat elemen utama yang dimiliki ameliorasi iklim adalah radiasi matahari, suhu udara, kelembaban udara, dan pergerakan angin (Grey dan Deneke 1978). RTH dapat mengatur keempat elemen iklim ameliorasi iklim dengan penggunaan vegetasi yang sesuai di ruang terbuka yang ada.

Suhu merupakan salah satu elemen yang sangat mempengaruhi kenyamanan lingkungan. Menurut Keputusan Menteri Kesehatan No.829/Menkes/SK/VII/ 1999, suhu udara yang nyaman bagi lingkungan permukiman sehat yaitu sekitar $18-30^{\circ} \mathrm{C}$. Kenyamanan thermal telah diteliti oleh para ahli, salah satunya yaitu secara kuantitatif dengan metode Temperature Humidity Index (THI). THI merupakan suatu indeks untuk menetapkan efek kondisi panas pada kenyamanan manusia dengan menghubungkan antara suhu dan kelembaban udara, yang secara empiris dirumuskan Nieuwolt (1975) (Effendi et al. 2006). Menggunakan rumus Niewolt (1975), Emmanuel (2005) dalam Pratama (2013) menyatakan bahwa $100 \%$ populasi manusia merasa nyaman pada THI antara $21-24{ }^{\circ} \mathrm{C}$. Pada THI sebesar $25-27{ }^{\circ} \mathrm{C}, 50 \%$ populasi manusia masih menyatakan nyaman sedangkan pada THI $>27{ }^{\circ} \mathrm{C}, 100 \%$ populasi manusia menyatakan tidak nyaman. Vegetasi dapat mengontrol/mengameliorasi suhu dengan mengkontrol radiasi matahari. Menurut Grey dan Daneke (1978), efektifitas vegetasi dalam menangkap radiasi matahari tergantung pada kepadatan daun, bentuk daun, dan pola percabangan. Derajat pengontrolan radiasi sinar matahari, antara lain : (1) tanaman hijau mereduksi sampai $80 \%$ penetrasi cahaya, (2) pohon yang berdaun lebat dapat mereduksi penetrasi cahaya antara $51-54 \%$ dan melindungi dari sinar matahari langsung sepanjang hari, (3) semak dan groundcover (penutup tanah dari 
rerumputan/soft material) mereduksi suhu dengan absorbsi radiasi dan evaporasi, dan (4) pada siang hari yang panas, rumput bisa mereduksi $5.5-7,8^{\circ} \mathrm{C}$ lebih dingin dari tanah terbuka (Femy 2014).

Angin merupakan salah satu elemen dalam ameliorasi iklim. Ketika kondisi di luar ruangan tidak nyaman pada siang hari karena suhu yang tinggi, angin dapat memberi kenyamanan dengan meningkatkan penguapan pendinginan (Grey dan Daneke 1978). Di sisi lain angin juga memiliki sifat merusak bila kecepatannya tinggi. Vegetasi seperti pohon dan semak dapat mengontrol angin dengan menghalangi, mengarahkan, membelokkan, dan menyaring angin. Vegetasi dapat mengurangi kecepatan angin sebesar 75-85\%. Kemudian menurut Carpenter et al. (1975), komposisi tanaman yang berbeda dapat mengurangi kecepatan angin sekitar 40-50\%. Efeknya bervariasi tergantung ukuran spesies, bentuk daun, kepadatan dan retensi daun, dan posisi penempatan vegetasi (Grey dan Daneke 1978).

Kelembaban udara merupakan kandungan uap air di udara. Kelembaban air sangat dipengaruhi oleh suhu udara, dimana semakin tinggi suhu udara maka kelembaban udara menjadi rendah karena kapasitas untuk menampung uap air pun rendah. Kelembaban yang ideal menurut Laurie (1986) adalah sekitar 40-75\%. Kelembaban di bawah tajuk lebih tinggi dan evaporasi lebih rendah sehingga suhu menjadi lebih rendah dari lingkungan sekelilingnya ketika siang hari dan hangat ketika malam hari (Grey dan Daneke 1978). Kelembaban yang mendekati kenyamanan terdapat pada bagian pohon dengan kerapatan daun yang rendah (Bianpoen et al. 1989).

\section{Estetika}

Simonds (1983) menyatakan estetika merupakan hubungan yang harmonis dari semua elemen atau komponen yang dirasakan. Estetika dalam lanskap dapat berarti suatu keindahan yang dapat mempengaruhi kualitas suatu lingkungan dan merupakan salah satu sumber daya alam (SDA) sehingga perlu dilestarikan dan ditingkatkan kualitasnya.

Komponen dari suatu obyek dalam menentukan tingkat estetikanya dapat ditentukan melalui dua penilaian, yaitu formal dan simbolik. Estetika formal menilai suatu obyek berdasarkan bentuk, ukuran, warna, kompleksitas, dan keseimbangan suatu obyek. Sedangkan estetika simbolik menilai suatu obyek berdasarkan pada makna konotatif dari obyek tersebut setelah dialami oleh pengamat (Nassar 1988). Salah satu upaya yang dilakukan manusia adalah perlindungan terhadap kualitas keindahan lingkungan. Kualitas estetika suatu lanskap secara langsung dapat memberikan kepuasan pada seseorang, dan secara tidak langsung dapat mempengaruhi perilaku manusia. Kualitas estetika mempunyai kontribusi dalam membentuk karakter dan identitas suatu tempat (Heath 1988). 


\section{Scenic Beauty Estimation (SBE)}

Scenic Beauty Estimation (SBE) merupakan suatu metode untuk menilai suatu lanskap atau objek lanskap berdasarkan keindahan yang disukai. Metode ini menggunakan kuesioner untuk mengetahui preferensi masyarakat terhadap suatu fanskap tertentu. Penerapan metode SBE terdiri dari tiga langkah utama, yaitu pengambilan foto lanskap, presentasi slide foto, dan analisis data (Daniel dan Boster 1976).

Pengambilan foto lanskap dilakukan dengan posisi setinggi mata, objek tidak terhalang benda lain, dan merupakan vintage point. Foto yang telah difoto kemudian dipresentasikan kepada responden dengan slide yang diperlihatkan selama durasi masing-masing \pm 10 detik (Hidayat 2009). Metode SBE mengukur preferensi masyarakat dengan penilaian melalui sistem rating dengan skala 1-10 terhadap slide foto, semakin tinggi nilainya makan semaik baik kualitas dari Tanskap. Menurut Kaplan (1988) penilaian manusia terhadap pemandangan melalui foto sama baiknya dengan menilai pemandangan secara langsung. Hasil dari SBE memperlihatkan konfigurasi vegetasi seperti apa yang dapat memberi nilai estetika tinggi dan banyak disukai.

\section{Persepsi dan Preferensi Masyarakat}

Kata persepsi menurut Kamus Besar Bahasa Indonesia didefinisikan sebagai proses seseorang mengetahui beberapa hal melalui panca indera. Persepsi merupakan stimulus yang diindera oleh individu, diorganisasikan kemudian diinterpretasikan sehingga individu menyadari dan mengerti tentang apa yang diindera (Uma 2015), maka dari itu persepsi manusia pasti berbeda-beda. Eckbo (1964) berpendapat bahwa persepsi dipengaruhi oleh latar belakang intelektual dan pengalaman emosional, pergaulan dan sikap seseorang. Semakin intelek dan banyak pengalaman emosional yang dimiliki seseorang akan semakin dalam persepsi seseorang terhadap suatu objek.

Preferensi merupakan kecenderungan seseorang untuk memilih suatu pilihan yang dipengaruhi oleh banyak faktor. Menurut Abello dan Bernaldez (1986) faktor-faktor yang mempengaruhi preferensi masyarakat antara lain usia, jenis kelamin, tingkat sosial, tingkat pendidikan dan budaya. Preferensi juga dapat disebabkan rasa keterkaitan seseorang terhadap suatu tempat karena lamanya ia tinggal di tempat tersebut.

\section{Evaluasi}

Evaluasi adalah suatu proses untuk menaksir kinerja dan keluaran yang dihasilkan oleh suatu program (Arifin et.al 2008). Evaluasi pada suatu taman adalah menguji kesesuaian kondisi taman dengan rencana/rancangan taman dan kualitas yang standar serta pengelolaannya untuk perencanaan mendatang. Mekanisme evaluasi ini dilengkapi dengan perangkat pedoman (toolkit) yang meliputi standar prosedur operasi atau standard operating procedure (SOP) beserta indikator dan kriteria standar. Evaluasi dilakukan untuk menentukan 
keputusan apakah akan melanjutkan suatu program yang dinilai sukses atau apakah akan menghentikannya. Tujuan evaluasi adalah untuk mengoleksi dan menampilkan informasi yang diperlukan dalam mendukung pengambilan kesimpulan dan keputusan tentang suatu program serta nilainya. Hasil evaluasi digunakan untuk membantu memutuskan apakah suatu program akan dilanjutkan atau dihentikan dan bagaimana cara pengembangannya (Hidayat 2010).

\section{METODOLOGI}

\section{Lokasi dan Waktu Penelitian}

Penelitian dilaksanakan selama 8 bulan yaitu bulan Februari-September 2020 pada dua taman kota yang terletak di BSD City, Kota Tangerang Selatan. Taman tersebut yaitu Taman Kota 1 BSD dan Taman Kota 2 BSD.

Taman Kota 1 BSD berada di Jalan Letnan Sutopo, Tangerang Selatan dan Taman Kota 2 BSD yang berada di Jalan Tekno Widya, Taman Tekno, Tangerang Selatan (Gambar 2). Dua lokasi tersebut memiliki area yang cukup luas yaitu Taman Kota 1 BSD memiliki luas 2,6 Hektar dan Taman Kota 2 BSD memiliki luas 9 Hektar.

(a)

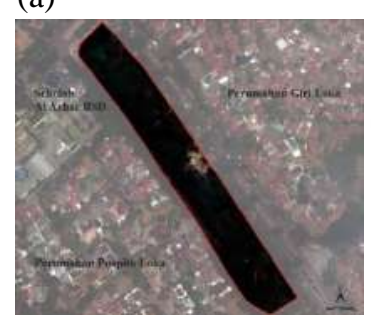

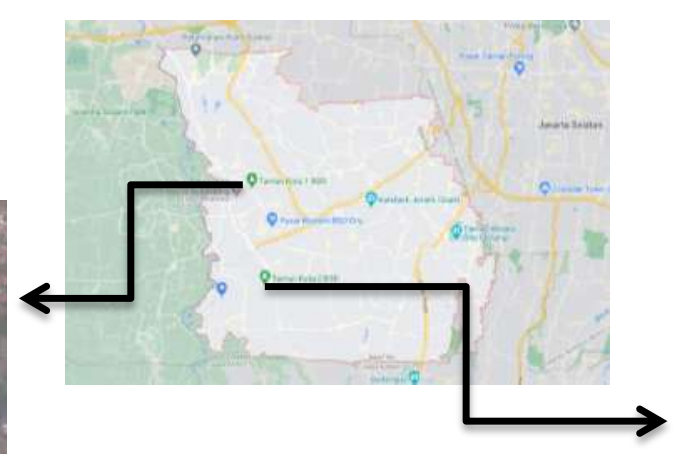

(b)

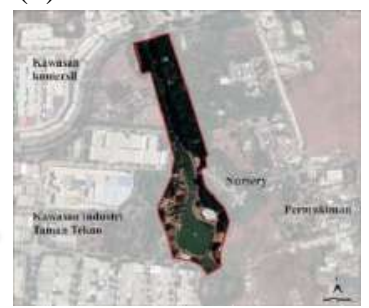

Gambar 2 Lokasi penelitian (a) Taman Kota 1 BSD, (b) Taman Kota 2 BSD Sumber: GoogleMaps (modifikasi)

\section{Alat dan Bahan}

Penelitian menggunakan beberapa peralatan antara lain: buku catatan, alat tulis, laptop, kamera digital, dan thermoghygrometer digital. Beberapa perangkat lunak juga digunakan, yaitu Microsoft Word, Microsoft Excel, Microsoft Power Point, AutoCAD 2013, Corel Draw 2017, dan IBM SPSS Statistics 24 sebagai pengolah data.

Bahan yang digunakan untuk penelitian ini terdiri dari dua sumber data yaitu data primer dan data sekunder. Data primer didapatkan dari hasil pengamatan langsung di lapangan untuk pengukuran suhu, kelembababan, serta wawancara dengan penyebaran kuesioner sebagai bahan untuk analisis persepsi 
dan preferensi masyarakat. Data sekunder didapatkan dari instansi terkait dan studi literatur.

\section{Metode Penelitian}

Metode penelitian ini mengacu pada penelitian yang dilakukan oleh Fathonah (2018). Pengumpulan data dilakukan dengan cara pengamatan di lapang, wawancara dengan pihak terkait, penyebaran kuesioner, dan studi literatur. Metode yang dilakukan pada penelitian ini dilakukan dalam beberapa tahapan kerja meliputi tahapan persiapan, inventarisasi, analisis, dan sintesis dengan menghasilkan rekomendasi penataan vegetasi (Gambar 3).

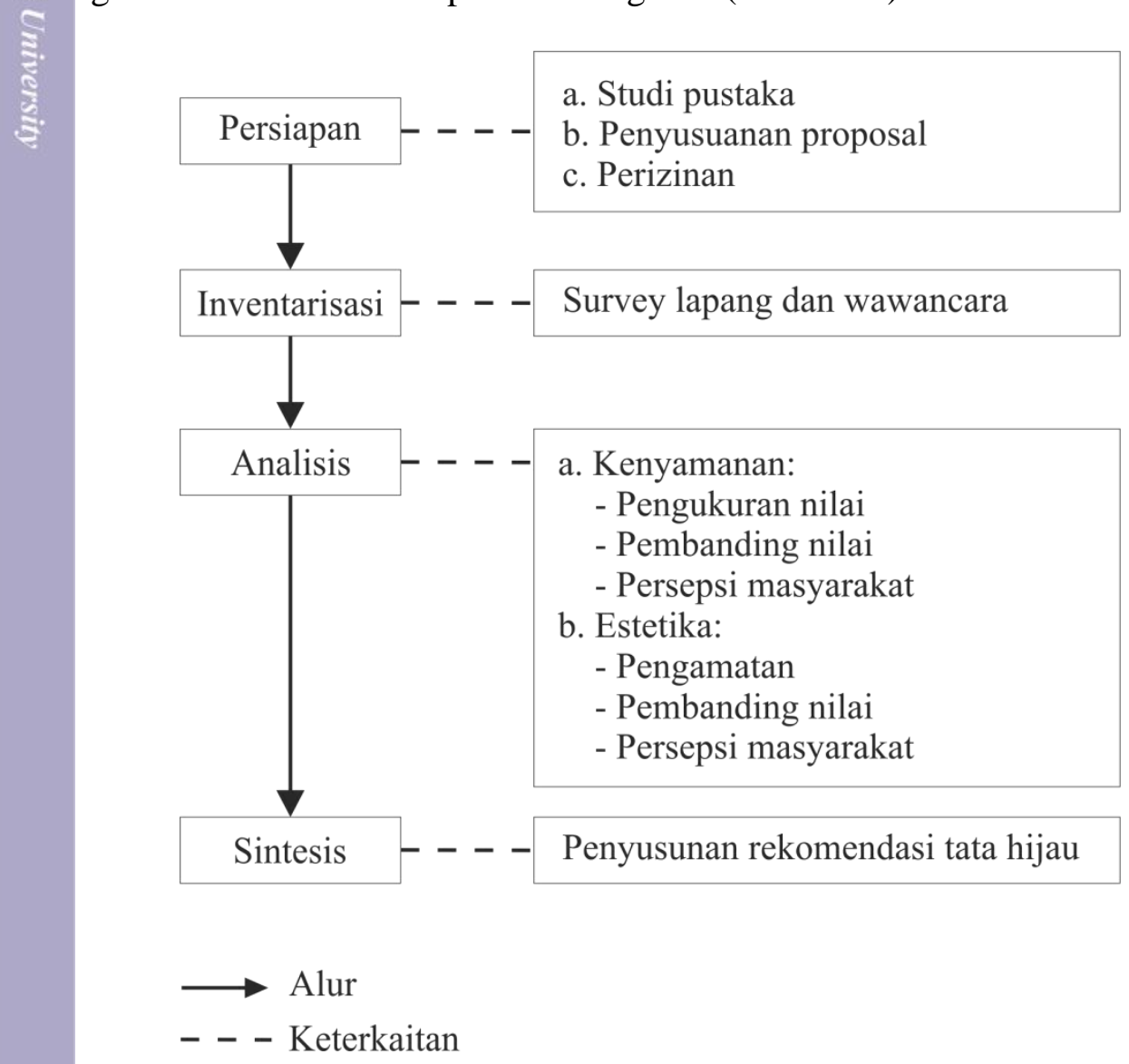

Gambar 3 Tahapan penelitian

\section{Persiapan}

Persiapan merupakan tahap awal dalam penelitian. Tahapan persiapan dilakukan dengan melakukan studi pustaka untuk mencari referensi dan pengumpulan data sekunder. Penyusunan proposal penelitian juga dilakukan pada tahap ini. Pengurusan perizinan penelitian juga dilakukan pada tahapan persiapan schingga penelitian dapat segera dilaksanakan. 


\section{Inventarisasi}

Inventarisasi adalah kegiatan pengumpulan data dan informasi terkait tapak penelitian. Data yang diperoleh pada tahap ini adalah data primer dan data sekunder. Data primer diperoleh dari hasil survei lapang secara langsung. Survei lapang dilakukan dengan pengamatan secara langsung di tapak, pengambilan dokumentasi, wawancara kepada pihak yang terkait, dan wawancara dengan kuesioner kepada responden. Data sekunder diperoleh dari hasil pencarian data ke dinas terkait dan studi pustaka.

Jenis data yang dibutuhkan mencakup data letak geografis, vegetasi, iklim mikro, dan persepsi masyarakat. Data iklim mikro diperoleh dengan pengukuran suhu dan kelembaban secara langsung di tapak untuk memperoleh suhu rata-rata dan untuk kemudian dianalisis sebagai parameternya terhadap penilaian vegetasi. Pengambilan gambar juga dilakukan pada masing-masing taman kota untuk dokumentasi dan bahan kelengkapan kuesioner. Wawancara dengan panduan kuesioner dilakukan dua kali, kepada pengunjung untuk mengetahui persepsi dan preferensi masyarakat mengenai kondisi dan kenyamanan lingkungan taman tersebut serta kepada responden khusus yang memiliki pemahaman lebih tentang ilmu arsitektur lanskap untuk menilai kualitas visual taman kota.

\section{Identifikasi Jenis dan Fungsi Tanaman}

Identifikasi jenis tanaman beserta fungsi penanamannya dilakukan khusus pada pepohonan. Identifikasi dilakukan oleh peneliti dengan inventarisasi secara langsung pada tapak. Penentuan fungsi penanaman pohon dilakukan berdasarkan kriteria pada Tabel 1. Jumlah jenis dan total individu pepohonan juga dihitung pada masing-masing RTH. Hasil identifikasi dan penghitungan pepohonan diperlukan dalam proses penilaian RTH.

Tabel 1 Kriteria fungsi penanaman pohon

\begin{tabular}{ll}
\hline Fungsi pohon & Kriteria pohon \\
\hline Peneduh & 1. Ketinggian tajuk lebih dari $2 \mathrm{~m}$ \\
& 2. Bentuk tajuk menyebar, bulat, kubah, irregular \\
3engarah & 3. Massa daun padat \\
& 1. Tanaman sejenis ditanam berulang \\
2. Jarak tanaman rapat \\
Estetika & 3. Pohon ditanam berbaris \\
& 1. Bentuk tajuk berskala horizontal (bulat, \\
& 2. Berbunga , menjurai, dan eksotis) \\
& 3. Daun berwarna mencolok
\end{tabular}

Sumber: DPU (1996)

\section{Pengukuran Iklim Mikro (Suhu dan Kelembaban Udara)}

Data suhu dan kelembaban udara dibutuhkan sebagai pembanding penilaian fungsi ekologis. Pengukuran ini dilakukan di dalam dan di luar RTH, tujuannya adalah untuk mengetahui efek fungsi RTH sebagai pengontrol suhu dan kelembaban perkotaan. Taman Kota 1 BSD dibagi menjadi tiga segmen untuk wilayah pengukuran (Gambar 6) dan Taman Kota 2 BSD dibagi menjadi 2 segmen (Gambar 7). Setiap segmen diambil beberapa titik pengukuran dengan 
kriteria tertentu. Kriteria untuk pengambilan titik, yaitu: 1) di atas rumput tanpa naungan, 2) di atas rumput dengan naungan rapat, 3) di atas perkerasan tanpa naungan, 4) di atas perkerasan dengan naungan rapat, 5) di atas rumput dengan naungan renggang, 6) di atas perkerasan dengan naungan renggang.

Jarak tanam antarpohon digolongkan rapat apabila $\leq 4 \mathrm{~m}$ serta tajuk dari masing-masing pohon saling bertautan (Gambar 4). Sementara itu, jarak tanam antarpohon digolongkan jarang apabila jarak tanam antarpohon $>4 \mathrm{~m}$ (Gambar 5).
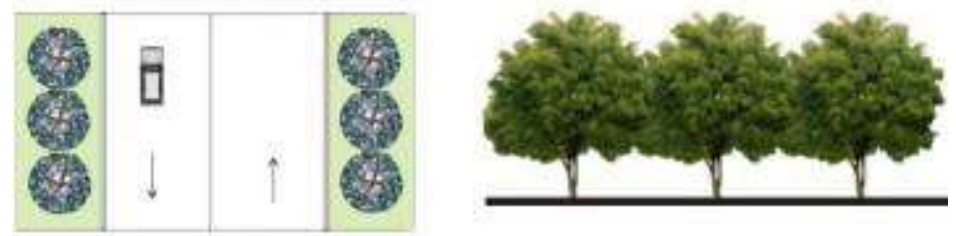

Sumber : Direktorat Jenderal Bina Marga (2010)

Gambar 4 Sketsa jarak tanam antarpohon rapat
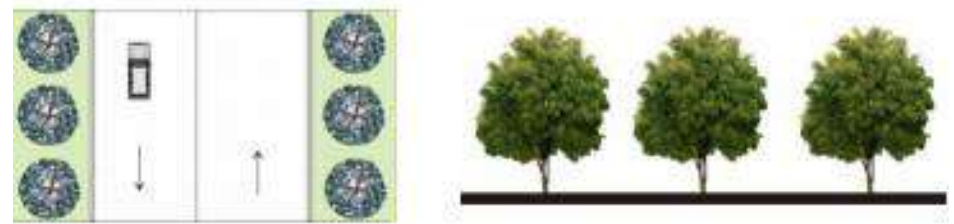

Sumber : Direktorat Jenderal Bina Marga (2010)

Gambar 5 Sketsa jarak tanam antarpohon jarang

Pengukuran suhu dan kelembaban dilakukan secara langsung oleh peneliti dengan tiga kali waktu pengukuran dalam sehari yaitu saat pagi (pukul 07.0009.00 WIB), siang (pukul 11.00-13.00 WIB), dan sore hari (pukul 15.00-17.00 WIB) pada setiap RTH. Pengukuran dilakukan tiga kali pengulangan pada hari yang berbeda hingga didapatkan suhu udara rata-rata dan kelembaban rata-rata di dalam RTH.

Pengukuran di luar RTH dilakukan dengan menentukan titik pengukuran yang berjarak kurang lebih 10 meter ke arah luar dari RTH publik. Titik pengukuran adalah lokasi yang mudah dijangkau dan disesuaikan dengan kondisi eksisting pada tapak. 


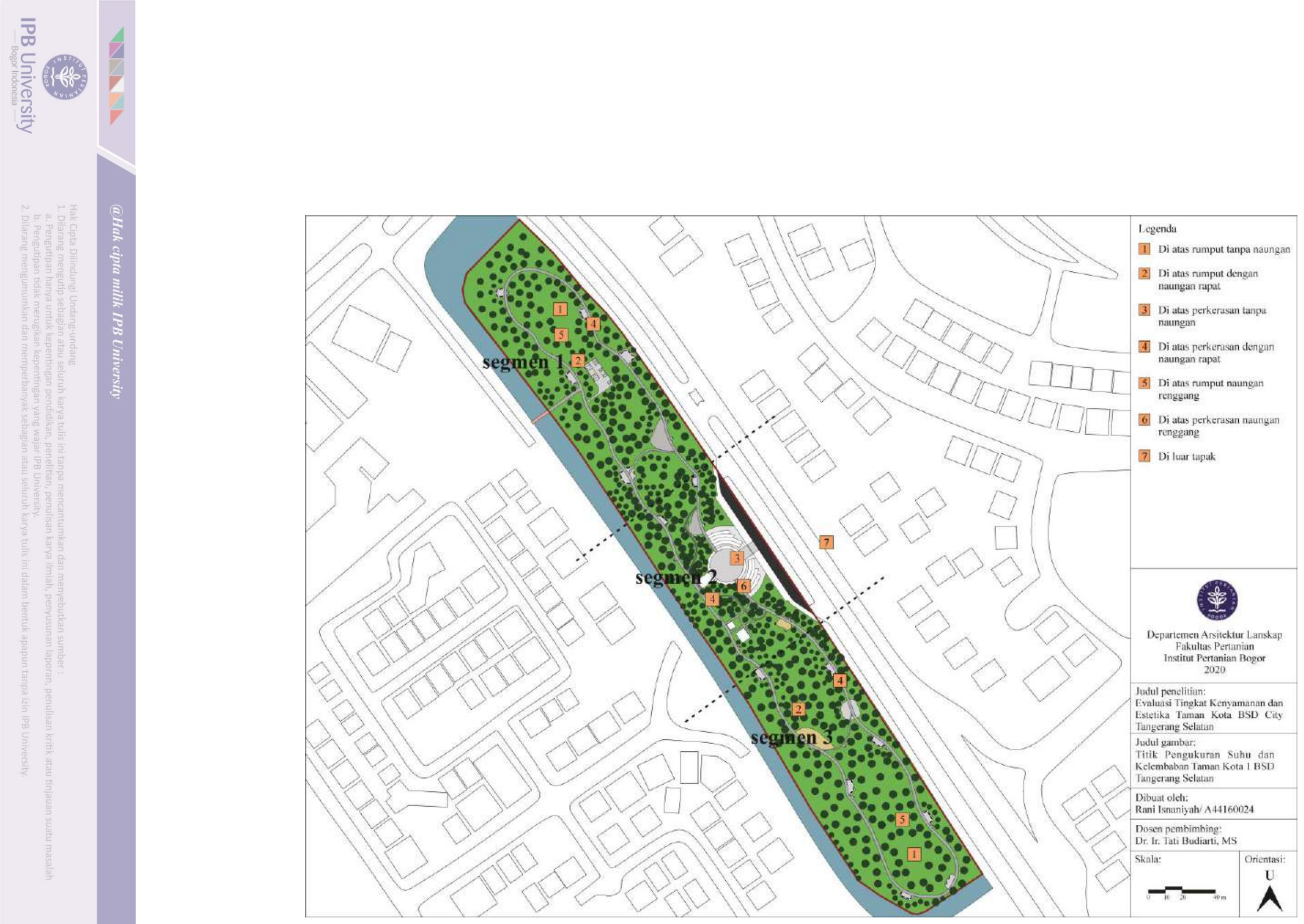

Gambar 6 Titik Pengukuran suhu dan kelembaban Taman Kota 1 BSD 


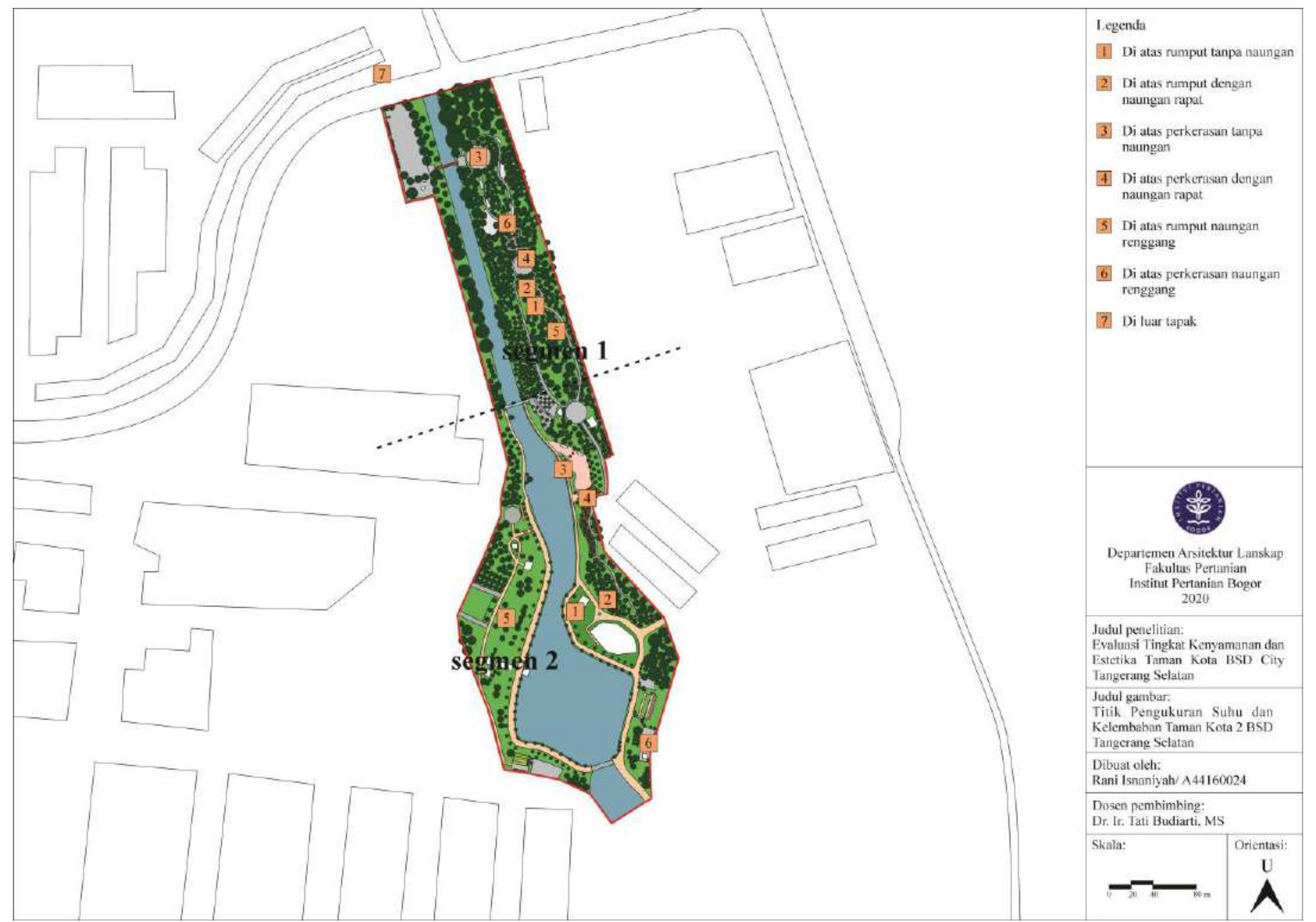

Gambar 7 Titik Pengukuran suhu Taman Kota 2 BSD 


\section{Pemotretan Foto Lanskap}

Objek pengambilan foto ditentukan berdasarkan fungsi area pada RTH yang dibagi sesuai dengan kondisi eksisting tapak. Titik pemotretan yang dilakukan adalah dengan sudut pandang sejajar dan posisi setinggi mata. Pemotretan dilakukan dengan menggunakan kamera digital. Gambar diambil dengan titik fokus tertinggi dan diusahakan tidak terhalang oleh bangunan atau tanaman lain. Pemotretan dilakukan secara langsung oleh peneliti pada waktu siang hari dimana kondisi taman sedang tidak terlalu banyak pengunjung sehingga objek yang difoto tidak terhalangi oleh pengunjung.

\section{Persepsi dan Preferensi Masyarakat}

Pengambilan data sosial berupa persepsi dan preferensi pengunjung dilakukan dengan wawancara dengan panduan kuesioner kepada pengunjung Taman Kota 1 BSD dan Taman Kota 2 BSD. Pengambilan data pada awalnya dilakukan dengan cara wawancara langsung dengan pengunjung pada kedua taman tersebut. Akan tetapi, adanya pandemi covid-19 mengakibatkan tidak memungkinkan melanjutkan wawancara secara langsung. Pengambilan data persepsi dan preferensi masyarakat dilanjutkan menggunakan kuisioner online dengan kriteria responden yaitu pernah mengunjungi Taman Kota 1 BSD atau Taman Kota 2 BSD dalam kurun waktu 1 tahun terakhir. Pertanyaan yang diberikan terkait karakteristik pengunjung, tujuan, pendapat dan keinginan pengunjung mengenai taman kota tersebut. Jumlah responden untuk setiap RTH publik 40 responden sehingga total responden dari kedua $\mathrm{RTH}$ publik yang diteliti yaitu 80 responden.

\section{Analisis}

Analisis data dilakukan secara deskriptif dan analisis kuantitatif. Pada tahap ini akan dilakukan identifikasi jenis vegetasi beserta fungsinya dan identifikasi karakter RTH dari segi desain dan pemilihan jenis tanaman. Hasil inventarisasi dianalisis berdasarkan kriteria fungsi ekologis yang kemudian dibandingkan dengan literatur.

\section{Analisis Tingkat Kenyamanan}

Dasar penilaian untuk tingkat kenyamanan disesuaikan dengan kriteria fungsi ekologis tanaman lanskap berdasarkan literatur (Tabel 2). Variabel penilaian untuk fungsi ekologis tanaman terdiri atas fungsi modifikasi suhu (peneduh), kontrol kelembaban udara, dan penahan angin. Teknik penilaian fungsi tanaman menggunakan rumus Key Performance Index (KPI) untuk memberi nilai pada masing-masing kriteria (Hidayat 2008). Nilai tertinggi yang diberikan adalah 4 dan yang terendah adalah 1. Selanjutnya hasil penilaian dibedakan menjadi kategori sangat baik, baik, sedang, dan buruk, serta dihitung persentasenya terhadap total jenis dan total individu tanaman. 
Tabel 2 Kriteria penilaian fungsi ekologis tanaman

\begin{tabular}{|c|c|}
\hline Variabel & Kriteria Penilaian \\
\hline Kontrol kelembaban udara & $\begin{array}{l}\text { 1. Ketinggian kanopi lebih dari } 2 \text { m (Simonds } \\
\text { 1983) } \\
\text { 2. Bentuk tajuk spreading, bulat, dome, } \\
\text { irregular (DPU Dirjen Bina Marga 1996) } \\
\text { 3. Massa daun padat (DPU Dirjen Bina Marga } \\
\text { 1996) } \\
\text { 4. Daun tebal (Carpenter et al. 1975) } \\
\text { 1. Kerapatan daun rendah (Bianpoen et al. } \\
\text { 1989) } \\
\text { 2. Berdaun jarum atau kasar (Grey dan Deneke } \\
\text { 1978) } \\
\text { 3. Tekstur batang kasar (Grey dan Deneke } \\
\text { 1978) } \\
\text { 4. Jumlah daun banyak (Carpenter et al. 1975) } \\
\text { 1. Tanaman tinggi (Carpenter et al. 1975) } \\
\text { 2. Daunnya tidak mudah gugur (Dahlan 1992) } \\
\text { 3. Massa daun rapat (DPU Dirjen Bina Marga } \\
\text { 1996) } \\
\text { 4. Berdaun tebal (DPU Dirjen Bina Marga } \\
\text { 1996) }\end{array}$ \\
\hline
\end{tabular}

Sumber: Mahardi 2013

Penilaian:

$\mathrm{KPI}=\frac{\text { jumlah masing-masing kriteria penilaian }}{\text { jumlah ideal (total maksimum)masing-masing kriteria }}$

Kategori (Hidayat, 2008):

Nilai 1: Buruk, bila $\leq 40 \%$ kriteria terpenuhi

Nilai 2: Sedang, bila 41-60\% kriteria terpenuhi

Nilai 3: Baik, bila 61-80\% kriteria terpenuhi

Nilai 4: Sangat baik, bila $\geq 81 \%$ kriteria terpenuhi

Persentase terhadap total jenis $=\frac{\text { jumlah jenis tanaman kategori } \mathrm{x}}{\text { total jenis tanaman }} \times 100 \%$

Persentase terhadap total individu $=\frac{\text { jumlah individu tanaman kategori } \mathrm{x}}{\text { total individu tanaman }} \times 100 \%$

Skor per RTH publik = $($ Persentase terhadap total individu kategori Buruk x 1) + Gersentase terhadap total individu kategori Sedang x 2) + (Persentase terhadap total individu kategori Baik x 3) + (Persentase terhadap total individu kategori Sangat baik x 4) 
Kategori skor per RTH:

Nilai 1: Buruk, bila skor $\leq 200$

Nilai 2: Sedang, bila skor 201-300

Nilai 3: Baik, bila skor $>300$

Selanjutnya hasil penilaian dibandingkan dengan pengukuran iklim mikro yang meliputi suhu udara dan kelembaban udara dianalisis dengan membandingkan kondisi iklim mikro pada tapak dengan kondisi kenyamanan ideal. Indeks kenyamanan iklim mikro dihitung menggunakan rumus Thermal Humidity Index (THI). Berdasarkan Mulyana et al. (2003) dalam Pratama (2013) kondisi nyaman ideal di Indonesia adalah indeks THI yang berkisar antara 20-26. Formulasi THI adalah sebagai berikut:

$\mathrm{THI}=0.8 \mathrm{~T}+(\mathrm{RH} \times \mathrm{T}) / 500$

Keterangan:

THI = Thermal Humidity Index

$\mathrm{T}=$ Suhu udara $\left({ }^{\circ} \mathrm{C}\right)$

$\mathrm{RH}=$ Kelembaban udara $(\%)$

\section{Analisis Kualitas Estetika}

Penilaian dan evaluasi untuk kualitas estetika dilakukan dengan menerapkan metode Scenic Beauty Estimation (SBE) yang diperkenalkan oleh Daniel dan Boster (1976). Penerapan metode SBE terdiri dari tiga langkah utama, yaitu: (1) pengambilan foto lanskap, (2) presentasi slide foto, dan (3) analisis data.

Responden yang dituju adalah orang yang sudah mendapatkan pemahaman lebih jauh tentang ilmu arsitektur lanskap, yaitu mahasiswa Departemen Arsitektur Lanskap IPB minimal semester 4 sebanyak 30 mahasiswa yang telah mengambil MK. Teori Desain Lanskap. Harapannya responden dapat menilai secara objektif terkait kualitas estetika yang akan dievaluasi. Penilaian kualitas estetika dilakukan dengan melihat presentasi slide foto yang ditayangkan dengan durasi 10 detik untuk masing-masing foto. Presentasi slide foto dilakukan melalui komunikasi video karena kondisi ketika penelitian sedang pandemi covid-19 sehingga tidak bisa melakukan pertemuan secara langsung dengan responden.

Hasil penilaian responden selanjutnya diolah secara statistik dengan perhitungan SBE berdasarkan skala penilaian $1-10$. Penilaian yang dilakukan oleh responden kemudian akan diubah menjadi sebuah nilai dengan menggunakan formulasi sebagai berikut:

$$
\mathrm{Z}_{\mathrm{ij}}=\frac{\mathrm{R}_{\mathrm{ij}}-\overline{\mathrm{R}}_{\mathrm{j}}}{\mathrm{S}_{\mathrm{j}}}
$$

Keterangan:

$\mathrm{Z}_{\mathrm{ij}} \quad=$ Standar penilaian untuk nilai respon ke $\mathrm{i}$ oleh responden $\mathrm{j}$

$\overline{\mathrm{R}}_{\mathrm{j}} \quad=$ nilai rata-rata dari semua nilai oleh responden $\mathrm{j}$

$\mathrm{R}_{\mathrm{ij}} \quad=$ nilai $\mathrm{i}$ dari responden $\mathrm{j}$

$\mathrm{S}_{\mathrm{j}} \quad=$ standar deviasi dari seluruh nilai oleh responden $\mathrm{j}$ 
Kemudian dilakukan tahap analisis terhadap data yang diperoleh dari tahap presentasi slide. Analisa data ditujukan untuk mendapatkan nilai SBE yaitu indeks kuantitas pendugaan keindahan suatu lanskap (Daniel dan Boster 1976). Tiap peringkat nilai dihitung frekuensi kumulatif, peluang kumulatif, nilai $Z$, dan nilai $Z$ rata - rata. Kemudian ditentukan satu nilai $Z$ dari foto lanskap tertentu sebagai standar (nilai Z yang paling mendekati nol). Nilai SBE diformulasikan sebagai berikut:

$$
\operatorname{SBEx}=(Z \mathrm{Lx}-\mathrm{ZLs}) \times 100
$$

\section{Keterangan:}

$$
\begin{array}{ll}
\text { SBEx } & =\text { Nilai SBE lanskap ke } \mathrm{x} \\
\text { ZLX } & =\text { Nilai rata-rata } Z \text { lanskap ke } \mathrm{x} \\
\text { ZLs } & =\text { Nilai rata-rata } Z \text { lanskap standar }
\end{array}
$$

Berdasarkan nilai SBE yang diperoleh, setiap objek dikelompokkan menjadi kualitas estetika rendah, kualitas estetika sedang, dan kualitas estetika tinggi. Pengelompokkan ini dilakukan dengan menggunakan standar oleh Daniel dan Boster (1976), yaitu kualitas estetika rendah memiliki nilai SBE $<-20$, kualitas estetika sedang apabila memiliki nilai SBE antara -20 sampai 20, dan kualitas estetika tinggi apabila nilai SBE > 20.

\section{Analisis Persepsi dan Preferensi Pengunjung}

Berdasarkan penyebaran kuisioner, dapat diketahui karakteristik pengunjung, tujuan, serta keinginan pengunjung pada tapak. Data persepsi dan preferensi pengunjung diolah dengan menggunakan metode statistik sederhana, kemudian dianalisis secara deskriptif. Hasil pengolahan data dibuat menjadi bagan atau diagram untuk penjelasan yang lebih mudah.

\section{Sintesis}

Pada tahap sintesis dirumuskan rekomendasi dari hasil analisis aspek kenyamanan dan estetika untuk penerapan tata hijau di RTH publik terkait aspek fungsi ekologis dan estetika. Rekomendasi ini dirumuskan sebagai acuan bagi pemerintah daerah dalam pengembangan RTH publik kota selanjutnya agar memberikan fungs kenyamanan dan estetika yang lebih optimal. 


\section{HASIL DAN PEMBAHASAN}

\section{Kondisi Umum}

\section{Letak, Luas, dan Batas Tapak}

Taman Kota 1 BSD berada di Jalan Letnan Sutopo, Tangerang Selatan. Taman Kota 1 BSD memiliki luas sekitar 2,6 ha. Lokasi taman terletak di antara perumahan dan sekolah. Sebelah utara dan timur taman terdapat Perumahan Giri Loka, sebelah selatan terdapat Perumahan Puspita Loka, dan sebelah barat terdapat Sekolah Islam Al-Azhar BSD (Gambar 8). Taman Kota 1 BSD bagian depan berbatasan dengan Jalan Letnan Sutopo dan bagian belakang berbatasan dengan sungai.

Taman Kota 2 BSD berada di Jalan Tekno Widya, Tangerang Selatan. Taman Kota 2 BSD memiliki luas sekitar 9 Ha dengan rincian luas bagian sungai sebesar $2 \mathrm{Ha}$ dan ruang terbuka seluas $7 \mathrm{Ha}$ (Wibisono 2008). Sebelah utara berbatasan dengan kawasan komersil, sebelah selatan berupa ruang terbuka dan beberapa nursery, sebelah timur berbatasan dengan lahan kosong, dan sebelah barat berbatasan dengan kawasan industri (Gambar 9).

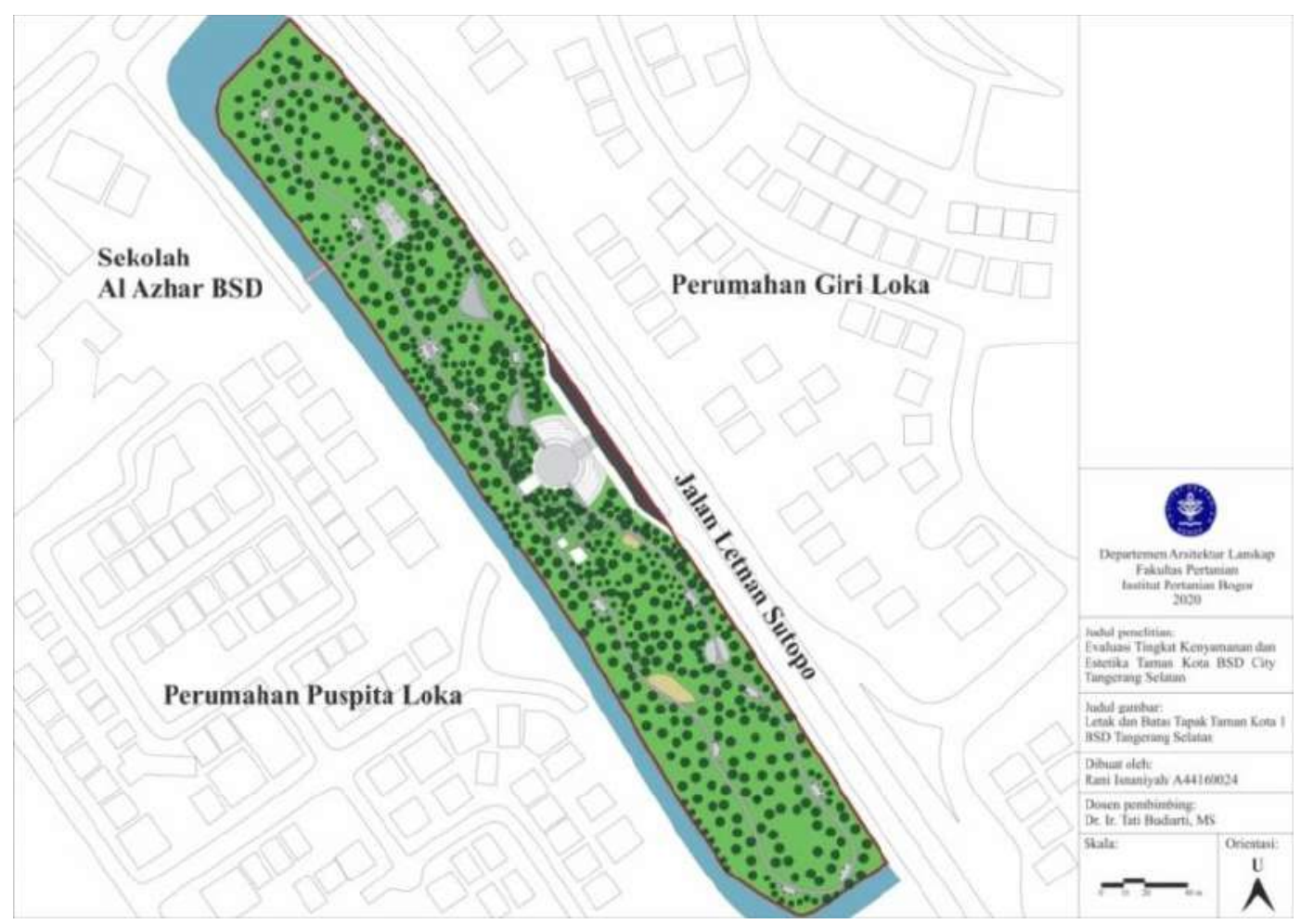

Gambar 8 Letak dan batas tapak Taman Kota 1 BSD 


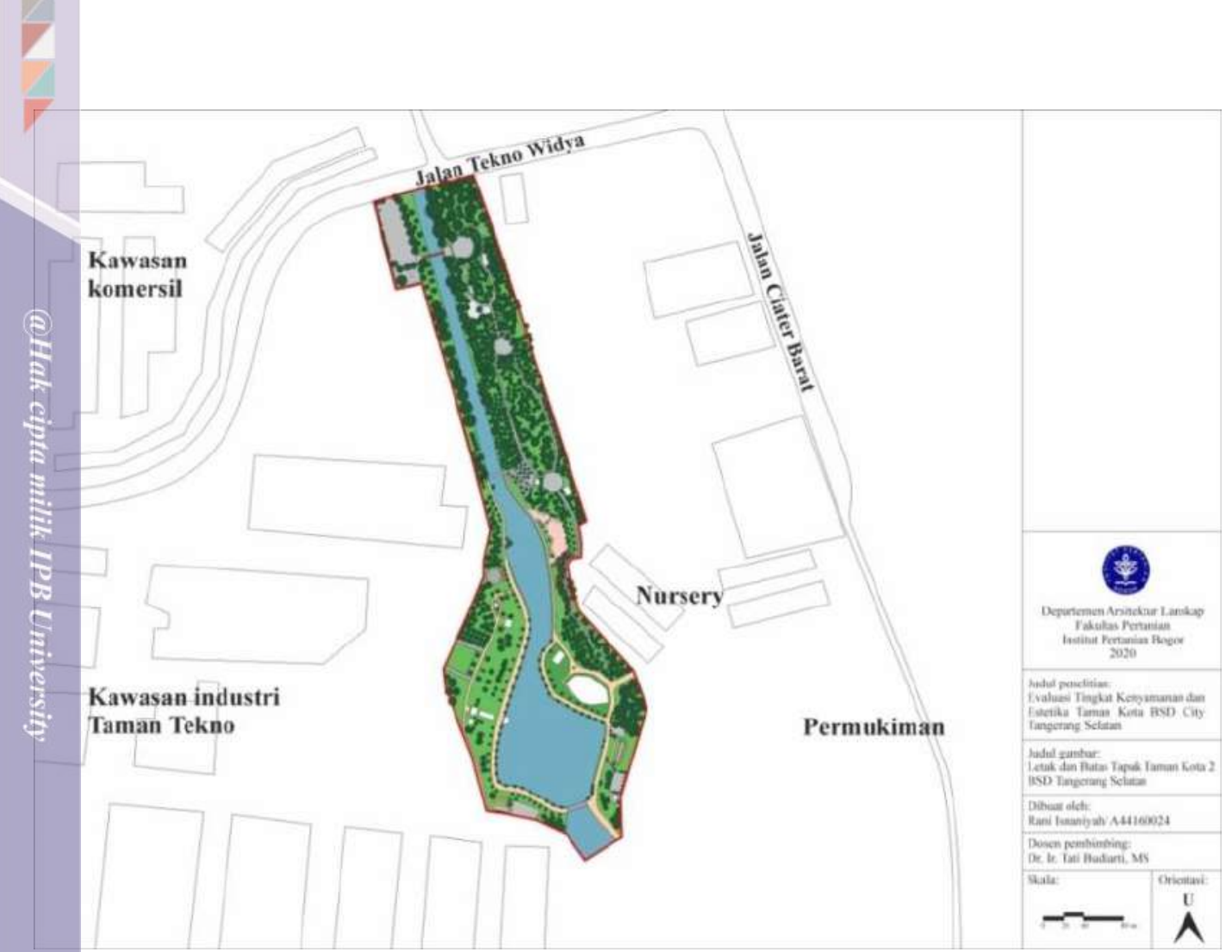

Gambar 9 Letak dan batas tapak Taman Kota 2 BSD

\section{Topografi}

BSD City terletak pada ketinggian 28-40 mdpl. Topografi BSD City relatif datar dengan kemiringan $0-5 \%$. Kondisi geologi ada dua jenis yaitu batuan gunung api muda yang mendominasi tapak serta alluvium di sepanjang pinggir sungai (PT. Arkonin, Perentjana Djaja, Pasific Consultans International Group, 1985).

Kondisi topografi pada Taman Kota 1 BSD adalah relatif datar, sedangkan Taman Kota 2 BSD memiliki kondisi topografi yang bervariasi dari datar hingga agak curam. Kemiringan di luar kawasan Taman Kota 2 BSD terlihat lebih datar sedangkan di dalam kawasan tersebut lebih beragam. Kemiringan di dalam kawasan taman tersebut sekitar 2-25\%.

\section{Iklim}

Berdasarkan data yang didapatkan dari BMKG Kota Tangerang Selatan tahun 2020, suhu minimum terjadi pada bulan Mei sebesar $34,6^{\circ} \mathrm{C}$, sedangkan suhu maksimal terjadi pada bulan Juni sebesar $37,2^{\circ} \mathrm{C}$. Suhu udara rata-rata maksimum periode Januari-Agustus 2020 sebesar $30,4^{\circ} \mathrm{C}$. Kelembaban rata-rata terendah terjadi pada bulan Juli sebesar $60 \%$ sedangkan kelembaban tertinggi terjadi pada bulan Januari sebesar $84 \%$. Kecepatan angin rata-rata pada peridode Januari-Agsustus 2020 berkisar 1-3 m/s. Curah hujan tertinggi terjadi di bulan Januari sebesar $208.9 \mathrm{~mm} /$ bulan dan kemudian mengalami penurunan pada bulanbulan berikutnya (Tabel 3). 
Tabel 3 Data iklim rata-rata Kota Tangerang Selatan tahun 2020

\begin{tabular}{|c|c|c|c|c|c|c|}
\hline \multirow[b]{2}{*}{ Bulan } & \multicolumn{3}{|c|}{ Temperatur $\left({ }^{\circ} \mathrm{C}\right)$} & \multirow[b]{2}{*}{$\begin{array}{l}\text { Kelembaban } \\
\text { rata-rata }(\%)\end{array}$} & \multirow{2}{*}{$\begin{array}{l}\text { Kecepatan } \\
\text { angin rata- } \\
\text { rata }(\mathrm{m} / \mathrm{s})\end{array}$} & \multirow{2}{*}{$\begin{array}{l}\text { Curah hujan } \\
\text { rata-rata } \\
\text { (mm/bulan) }\end{array}$} \\
\hline & Maksimum & Minimum & $\begin{array}{l}\text { Rata- } \\
\text { rata }\end{array}$ & & & \\
\hline Januari & 36,4 & 22,6 & 29,2 & 78 & $1-3$ & 208,9 \\
\hline Februari & 34,8 & 22,7 & 29 & 77 & $1-3$ & 86,7 \\
\hline Maret & 36,2 & 23,2 & 29,2 & 76 & $1-3$ & 44,6 \\
\hline April & 34,8 & 24,2 & 30,4 & 72 & $1-3$ & 79,5 \\
\hline Mei & 34,6 & 23,6 & 29,9 & 72 & $1-3$ & 70,2 \\
\hline Juni & 37,2 & 21,2 & 29,7 & 66 & $1-3$ & 14,2 \\
\hline Juli & 35,8 & 24,4 & 29 & 60 & $1-2$ & 34,9 \\
\hline Agustus & 35,6 & 23,2 & 29,4 & 61 & $1-2$ & 37,2 \\
\hline
\end{tabular}

Sumber: BMKG Tangerang Selatan (2020)

\section{Aksesibilitas dan Sirkulasi}

Letak Taman Kota 1 BSD dan Taman Kota 2 BSD berada di sisi jalan sehingga mudah diakses oleh pengunjung. Akan tetapi, akses dengan menggunakan kendaraan umum tidak dapat langsung sampai kedua taman tersebut, dikarenakan tidak ada jalur umum transportasi yang melintas. Pengunjung yang datang mayoritas menggunakan kendaraan pribadi sehingga sering kali terjadi lonjakan jumlah parkir kendaraan di taman tersebut. Akan tetapi lahan parkir dikedua taman tidak dapat diperluas karena tidak adanya lahan yang memadai.

Sirkulasi yang terdapat di Taman Kota 1 BSD berupa jogging track yang mengelilingi bagian taman. Jogging track yang tersedia berukuran lebar 1,5 meter sehingga terasa sempit apabila berpapasan dengan yang jalan berlawanan arah. Taman Kota 2 BSD juga tersedia sirkulasi berupa jogging track. Ukuran jogging track di Taman Kota 2 BSD lebih lebar jika dibandingkan dengan Taman Kota 1 BSD, namun ada beberapa lokasi yang sudah mengalami kerusakan seperti retak dan berlubang.

\section{Fasilitas dan Objek}

Taman Kota 1 memiliki beberapa fasilitas dan objek yaitu area parkir, welcome area, jembatan, jalur refleksi, jogging track, fitness area, children playground, sitting area, skate park, mushala, dan toilet (Gambar 10). Area parkir terletak di depan pintu masuk kawasan dan ketika pengunjung yang datang ramai maka parkir kendaraan biasanya akan menjadi sampai ke tepi jalan raya yang ada di depan Taman Kota 1 BSD. Akan tetapi memang sudah tidak ada lahan untuk menambah luasan area parkir. Fasilitas yang sering ramai dikunjungi pengunjung adalah fitness area dan children playground. Fasilitas skate park sering kali beralih fungsi menjadi tempat anak-anak bermain seluncur di arena skate park. Mushala dan toilet yang tersedia masing-masing ada satu yang terletak tidak jauh dari welcome area.

Taman Kota 2 memiliki fasilitas dan objek yang tidak jauh berbeda dengan Taman Kota 1. Fasilitas dan objek yang tersedia di Taman Kota 2 di antaranya yaitu area parkir, welcome area, jembatan, amphiteater, plaza, gazebo, mushala, toilet, jogging track, fitness area, children playground, sitting area, dan skate park (Gambar 11). Fasilitas yang ramai dikunjungi adalah area plaza dan di lokasi ini ketika weekend terdapat kegiatan senam bersama. 


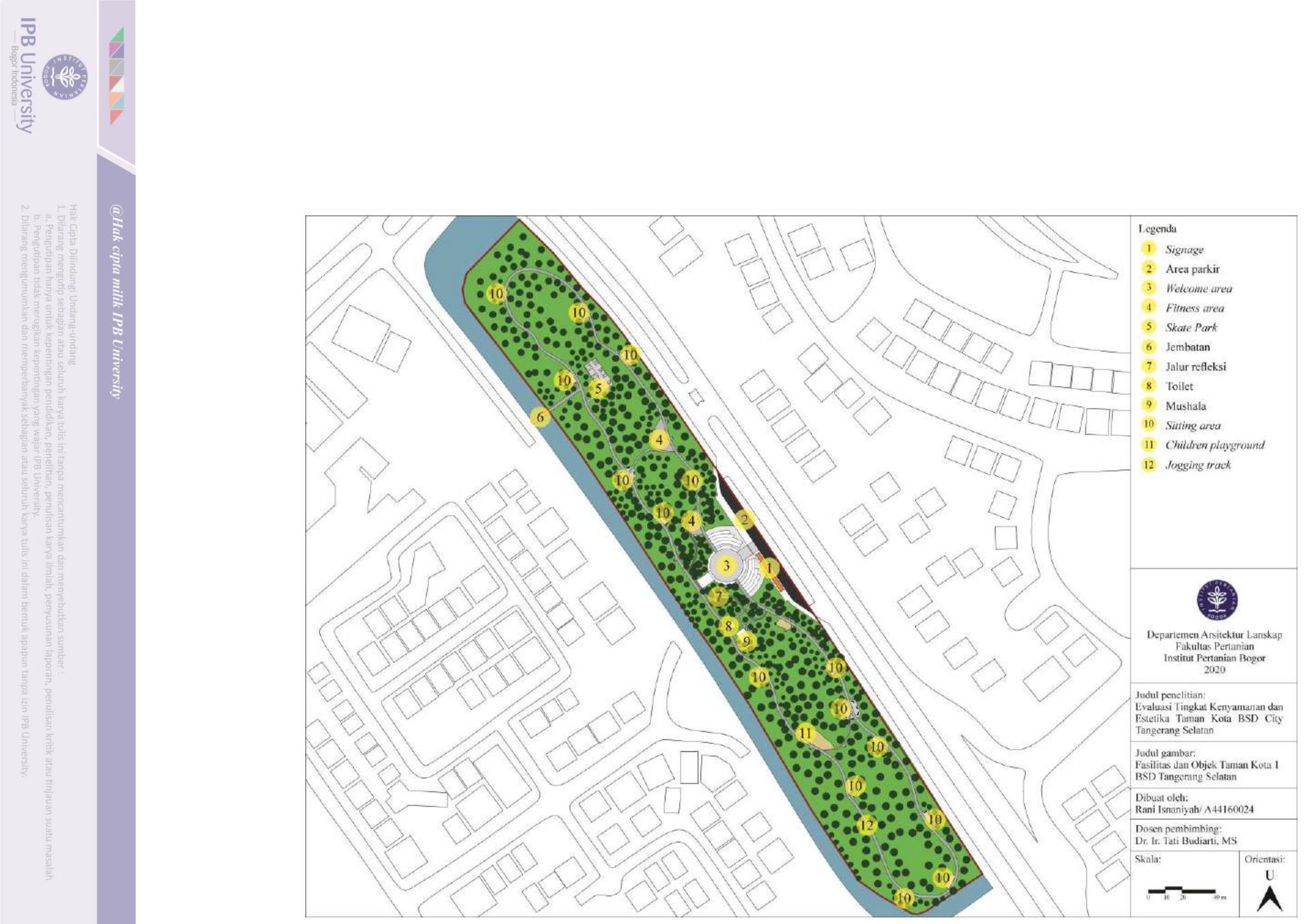

Gambar 10 Fasilitas dan objek pada Taman Kota 1 BSD 


\section{Identifikasi Jenis dan Fungsi Tanaman}

\section{Tanaman Taman Kota 1 BSD}

Taman Kota 1 BSD didominasi oleh tanaman jenis pepohonan yang berfungsi sebagai peneduh. Jumlah pohon di taman tersebut sebanyak 365 pohon yang jenisnya terdiri dari 46 spesies (Tabel 4). Jenis pohon yang paling banyak terdapat di taman terebut adalah Palem raja (Roystonea regia) yaitu sebanyak 47 pohon.

Tabel 4 Jenis dan fungsi pohon di Taman Kota 1 BSD

\begin{tabular}{|c|c|c|c|c|}
\hline No. & Nama Ilmiah & Nama Lokal & Fungsi & Jumlah \\
\hline$<1$ & Agathis alba & Kayu putih & Peneduh & 2 \\
\hline$\Xi 2$ & Agathis dammara & Damar & Pengarah & 15 \\
\hline 3 & Alstonia scholaris & Pulai & Peneduh & 10 \\
\hline 4 & Areca catechu & Pinang jambe & Estetika & 4 \\
\hline 5 & Artocarpus communis & Sukun & Peneduh & 8 \\
\hline 6 & Barringtonia asiatica & Butun & Peneduh & 12 \\
\hline 7 & Callistemon citrinus & Sikat botol & Estetika & 7 \\
\hline 8 & Cananga odorata & Kenanga & Peneduh & 3 \\
\hline 9 & Cassia siamea & Johar & $\begin{array}{l}\text { Peneduh, } \\
\text { estetika }\end{array}$ & 4 \\
\hline 10 & Ceiba pentandra & Kapuk & Peneduh & 7 \\
\hline 11 & Cerbera manghas & Bintaro & Peneduh & 12 \\
\hline 12 & $\begin{array}{l}\text { Chrysadilocarpus } \\
\text { lutescens }\end{array}$ & Palem kuning & Estetika & 2 \\
\hline 13 & Chrysophyllum cainito & Sawo duren & Peneduh & 7 \\
\hline 14 & Cynometra rammiflora & Nam-nam hutan & Peneduh & 3 \\
\hline 15 & Delonix regia & Flamboyan & Peneduh & 23 \\
\hline 16 & Diospyrus discolor & Bisbul & Peneduh & 17 \\
\hline 17 & Elaeis guinensis & Kelapa sawit & Estetika & 28 \\
\hline 18 & $\begin{array}{l}\text { Enterolobium } \\
\text { cyclocarpum }\end{array}$ & Sengon buto & Peneduh & 5 \\
\hline 19 & Ficus lyrata & Biola cantik & Peneduh & 9 \\
\hline 20 & Gnetum gnemon & Melinjo & Peneduh & 4 \\
\hline 21 & Hibiscus tiliaceus maroon & Waru merah & Estetika & 8 \\
\hline 22 & Khaya senegalensis & Khaya & Peneduh & 22 \\
\hline 23 & Kigelia africana & Pohon sosis & Peneduh & 8 \\
\hline 24 & Lagerstroemia indica & Bungur & $\begin{array}{l}\text { Peneduh, } \\
\text { estetika }\end{array}$ & 2 \\
\hline 25 & Livistona rotundifolia & Palem sadeng & Estetika & 4 \\
\hline 26 & Maniltoa gemmipara & Sapu tangan & Peneduh & 13 \\
\hline 27 & Michelia campaca & Cempaka & Peneduh & 4 \\
\hline 28 & Mimusop elengi & Tanjung & Peneduh & 3 \\
\hline 29 & Plumeria alba & Kamboja putih & $\begin{array}{l}\text { Peneduh, } \\
\text { estetika }\end{array}$ & 3 \\
\hline 30 & Plumeria rubra & Kamboja merah & $\begin{array}{l}\text { Peneduh, } \\
\text { estetika }\end{array}$ & 4 \\
\hline
\end{tabular}


Tabel 4 Jenis dan fungsi pohon di Taman Kota 1 BSD (lanjutan)

\begin{tabular}{|c|c|c|c|c|}
\hline No. & Nama Ilmiah & Nama Lokal & Fungsi & Jumlah \\
\hline 29 & Plumeria alba & Kamboja putih & $\begin{array}{l}\text { Peneduh, } \\
\text { estetika }\end{array}$ & 3 \\
\hline 30 & Plumeria rubra & Kamboja merah & $\begin{array}{l}\text { Peneduh, } \\
\text { estetika }\end{array}$ & 4 \\
\hline 31 & Polyathia longifolia & Glodogan tiang & Pengarah & 12 \\
\hline 32 & Pometia pinnata & Matoa & Peneduh & 4 \\
\hline 33 & Pterocarpus indicus & Angsana & Peneduh & 6 \\
\hline 34 & Roystonea regia & Palem raja & Estetika & 47 \\
\hline 35 & Samanea saman & Trembesi & Peneduh & 6 \\
\hline 36 & Schefflera actinophylla & Wali songo & Peneduh & 2 \\
\hline 37 & Shorea pinonga & Meranti & Peneduh & 2 \\
\hline 38 & Spathodea campanulata & Kecrutan & Peneduh & 3 \\
\hline 39 & Swietenia macrophylia & Mahoni & Peneduh & 2 \\
\hline 40 & Tabebuia pallida & Tabebuia & Estetika & 6 \\
\hline 41 & Tamarindus indica & Asam jawa & Peneduh & 2 \\
\hline 42 & Tectona grandis & Jati super & Peneduh & 3 \\
\hline 43 & Terminalia catappa & Ketapang & Peneduh & 3 \\
\hline 44 & Thevetia peruviana & Tevetia & $\begin{array}{l}\text { Peneduh, } \\
\text { estetika }\end{array}$ & 2 \\
\hline 45 & Veitchia merillii & Palem putri & Estetika & 4 \\
\hline 46 & Wodyetia bifurcate & $\begin{array}{l}\text { Palem ekor } \\
\text { tupai }\end{array}$ & Estetika & 8 \\
\hline
\end{tabular}

Pola penanaman di Taman Kota 1 BSD ada yang tunggal, berkelompok, dan linear mengikuti jalur perkerasan. Tanaman palem-paleman banyak ditanam dengan pola berkelompok, sedangkan pola linear yang biasa ditemui yaitu pohon Kupu-kupu. Tanaman lainnya lebih banyak ditanam secara tunggal dan tersebar di beberapa area.

\section{Tanaman Taman Kota 2 BSD}

Jumlah jenis pohon yang terdapat di Taman Kota 2 BSD yaitu 40 spesies dengan total individu sebanyak 722 pohon (Tabel 5). Taman Kota 2 BSD didominansi oleh pohon Pinus (Pinus merkusii) yang jumlahnya mencapai 306 pohon.

Fungsi tanaman di Taman Kota 2 BSD ada yang sebagai peneduh, pengarah, maupun estetika (Tabel 5). Tanaman peneduh jumlahnya lebih banyak dari tanaman dengan fungsi lainnnya. 
Tabel 5 Jenis dan fungsi pohon di Taman Kota 2 BSD

\begin{tabular}{|c|c|c|c|c|}
\hline No & Nama Ilmiah & Nama Lokal & Fungsi & Jumlah \\
\hline 1 & Acacia mangium & Akasia & Peneduh & 10 \\
\hline 2 & Agathis damara & Damar & Pengarah & 16 \\
\hline (2) 3 & Alstonia scholaris & Pulai & $\begin{array}{l}\text { Peneduh, } \\
\text { Pengarah }\end{array}$ & 10 \\
\hline 4 & Artocarpus altilis & Sukun & Peneduh & 10 \\
\hline 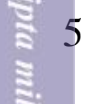 & Bauhinia purpurea & $\begin{array}{l}\text { Pohon kupu- } \\
\text { kupu }\end{array}$ & $\begin{array}{l}\text { Estetika, } \\
\text { Pengarah }\end{array}$ & 31 \\
\hline 6 & Butia capitata & Butia bonnetti & Estetika & 2 \\
\hline 7 & Cassuarina equisettifolia & Cemara & Peneduh & 15 \\
\hline 58 & Ceiba pentandra & Kapuk & Peneduh & 30 \\
\hline 9 & Cerbera odollam & Bintaro & Peneduh & 23 \\
\hline 10 & Chrysophyllum cainito & Sawo duren & Peneduh & 13 \\
\hline 11 & Delonix regia & Flamboyan & Peneduh & 48 \\
\hline 12 & Dillenia indica & Sempur & Peneduh & 1 \\
\hline 13 & Dimocarpus longan & kelengkeng & Peneduh & 4 \\
\hline 14 & Erythrina cristagali & Dadap merah & Estetika & 3 \\
\hline 15 & Ficus benjamina & Beringin & Peneduh & 4 \\
\hline 16 & Ficus lyrata & Biola cantik & Peneduh & 3 \\
\hline 17 & Filicium depiens & Kiara payung & Peneduh & 4 \\
\hline 18 & Hevea brasiliensis & Karet & Peneduh & 10 \\
\hline 19 & Intsia bijuga & Merbau & Peneduh & 2 \\
\hline 20 & Khaya antoteca & Khaya & Peneduh & 52 \\
\hline 21 & Kigelia africa & Pohon Sosis & Peneduh & 2 \\
\hline 22 & Leucaena leucocephala & Lamtoro & Peneduh & 6 \\
\hline 23 & Mangifera indica & Mangga & Peneduh & 3 \\
\hline 24 & Maniltoa grandiflora & sapu tangan & Peneduh & 3 \\
\hline 25 & Mimusop elengi & Tanjung & Peneduh & 8 \\
\hline 26 & Muntingia calabura & seri & Peneduh & 5 \\
\hline 27 & Murraya paniculata & Kemuning & Peneduh & 1 \\
\hline 28 & Peronema canescen & Sungkai & Peneduh & 3 \\
\hline 29 & Pinus merkusii & Pinus & Peneduh & 306 \\
\hline 30 & Plumeria sp. & Kamboja & Estetika & 15 \\
\hline 31 & Polyalthia fragrans & Glodogan bulat & Estetika & 2 \\
\hline 32 & Pometia pinnata & Matoa & Peneduh & 8 \\
\hline 33 & Roystonea regia & Palem raja & Peneduh & 10 \\
\hline 34 & Samanea saman & Trembesi & Peneduh & 13 \\
\hline 35 & Shorea sp. & Meranti & Peneduh & 2 \\
\hline 36 & Spatodhea campanulata & Kecrutan & Peneduh & 3 \\
\hline 37 & Switenia macrophylla & Mahoni & Peneduh & 5 \\
\hline 38 & Tabebuia chrysantha & Tabebuia & Estetika & 14 \\
\hline 39 & Terminalia catappa & Ketapang & Peneduh & 20 \\
\hline 40 & Terminalia mantaly & $\begin{array}{l}\text { Ketapang } \\
\text { kencana }\end{array}$ & Estetika & 2 \\
\hline & & & & 722 \\
\hline
\end{tabular}




\section{Evaluasi Fungsi Ekologis Tanaman}

Fungsi ekologis tanaman dalam taman kota memberikan peran penting untuk ameliorasi iklim yang akan berdampak terhadap tingkat kenyamanan. Ameliorasi iklim dilakukan tanaman dengan cara memodifikasi suhu, mengontrol kelembaban, dan mengatur aliran angin. Penelitian ini mengevaluasi seberapa besar fungsi ekologis tanaman di taman kota yang merupakan lokasi penelitian.

\section{Fungsi Modifikasi Suhu}

Suhu merupakan salah satu faktor yang mempengaruhi kenyamanan thermal. Kenyamanan thermal sangat dibutuhkan pengunjung di RTH perkotaan yang selalu ramai dikunjungi. Pemilihan dan penataan tanaman peneduh yang tepat dapat mengoptimalkan pemodifikasian suhu hingga mencapai kenyamanan thermal. Beberapa penelitian menyatakan bahwa pemilihan tanaman peneduh yang spesifik dapat berdasarkan struktur dan kerapatan tajuk, ukuran, bentuk, dan warna daun (Abreu-Habrich, Labaki, dan Matzarakis 2015).

Beberapa kriteria tanaman dalam fungsi modifikasi suhu antara lain:

K1= Ketinggian kanopi lebih dari $2 \mathrm{~m}$ (Simonds 1983)

$\mathrm{K} 2=$ Bentuk tajuk spreading, bulat, dome, irregular (DPU Dirjen Bina Marga 1996)

K3= Massa daun padat (DPU Dirjen Bina Marga 1996)

K4= Daun tebal (Carpenter et al. 1975)

Penilaian tanaman di setiap lokasi penelitian terhadap fungsi modifikasi suhu diperhitungkan berdasarkan keempat kriteria tersebut dan diuraikan dalam Tabel 6 dan 8 .

Penilaian aspek fungsi modifikasi suhu pada tanaman di Taman Kota 1 BSD didominasi oleh tanaman berkategori baik dengan persentase terhadap total jenis tanaman 52,17\% dan persentase terhadap total individu 67,12\% (Gambar 12). Tanaman dengan kategori sangat baik tersebar di berbagai area sekitar jogging track sehingga memberikan kenyamanan pada pengunjung ketika berkeliling taman.

Tabel 6 Penilaian aspek fungsi modifikasi suhu di Taman Kota 1 BSD

\begin{tabular}{|c|c|c|c|c|c|c|c|c|}
\hline \multirow{2}{*}{ No. } & \multirow{2}{*}{ Nama Ilmiah } & \multirow{2}{*}{$\begin{array}{l}\text { Nama } \\
\text { Lokal }\end{array}$} & \multicolumn{4}{|c|}{ Kriteria fungsi modifikasi suhu } & \multirow{2}{*}{ Skor } & \multirow{2}{*}{ Kategori } \\
\hline & & & K1 & $\mathrm{K} 2$ & K3 & K4 & & \\
\hline 1 & Agathis alba & Kayu putih & 4 & 1 & 3 & 1 & 56.25 & Sedang \\
\hline 2 & Agathis dammara & Damar & 4 & 1 & 4 & 2 & 68.75 & Baik \\
\hline 3 & Alstonia scholaris & Pulai & 3 & 4 & 4 & 4 & 93.75 & Sangat baik \\
\hline 4 & Areca catechu & $\begin{array}{l}\text { Pinang } \\
\text { jambe }\end{array}$ & 1 & 2 & 1 & 2 & 37.50 & Buruk \\
\hline 5 & Artocarpus communis & Sukun & 4 & 3 & 2 & 4 & 81.25 & Sangat baik \\
\hline 6 & Barringtonia asiatica & Butun & 4 & 4 & 4 & 3 & 93.75 & Sangat baik \\
\hline 7 & Callistemon citrinus & Sikat botol & 3 & 4 & 4 & 1 & 75.00 & Baik \\
\hline 8 & Cananga odorata & Kenanga & 3 & 4 & 3 & 2 & 75.00 & Baik \\
\hline 9 & Cassia siamea & Johar & 3 & 3 & 2 & 1 & 56.25 & Sedang \\
\hline 10 & Ceiba pentandra & Kapuk & 4 & 4 & 2 & 2 & 75.00 & Baik \\
\hline 11 & Cerbera manghas & Bintaro & 3 & 4 & 3 & 4 & 87.50 & Sangat baik \\
\hline 12 & $\begin{array}{l}\text { Chrysadilocarpus } \\
\text { lutescens }\end{array}$ & $\begin{array}{l}\text { Palem } \\
\text { kuning }\end{array}$ & 1 & 2 & 2 & 1 & 37.50 & Buruk \\
\hline 13 & Chrysophyllum cainito & Sawo duren & 3 & 3 & 4 & 3 & 81.25 & Sangat baik \\
\hline 14 & Cynometra rammiflora & $\begin{array}{l}\text { Nam-nam } \\
\text { hutan }\end{array}$ & 3 & 4 & 4 & 3 & 87.50 & Sangat baik \\
\hline
\end{tabular}


Tabel 6 Penilaian aspek fungsi modifikasi suhu di Taman Kota 1 BSD (lanjutan)

\begin{tabular}{|c|c|c|c|c|c|c|c|c|}
\hline \multirow{2}{*}{ No. } & \multirow{2}{*}{ Nama Ilmiah } & \multirow{2}{*}{$\begin{array}{l}\text { Nama } \\
\text { Lokal }\end{array}$} & \multicolumn{4}{|c|}{ Kriteria fungsi modifikasi suhu } & \multirow{2}{*}{ Skor } & \multirow{2}{*}{ Kategori } \\
\hline & & & K1 & $\mathrm{K} 2$ & K3 & K4 & & \\
\hline 15 & Delonix regia & Flamboyan & 4 & 4 & 3 & 1 & 75.00 & Baik \\
\hline 16 & Diospyrus discolor & Bisbul & 3 & 3 & 3 & 2 & 68.75 & Baik \\
\hline Q 17 & Elaeis guinensis & $\begin{array}{l}\text { Kelapa } \\
\text { sawit }\end{array}$ & 3 & 3 & 3 & 2 & 68.75 & Baik \\
\hline 18 & $\begin{array}{l}\text { Enterolobium } \\
\text { cyclocarpum }\end{array}$ & $\begin{array}{l}\text { Sengon } \\
\text { buto }\end{array}$ & 4 & 4 & 3 & 1 & 75.00 & Baik \\
\hline 19 & Ficus lyrata & $\begin{array}{l}\text { Biola } \\
\text { cantik }\end{array}$ & 4 & 4 & 3 & 4 & 93.75 & Sangat baik \\
\hline 20 & Gnetum gnemon & Melinjo & 4 & 1 & 3 & 3 & 68.75 & Baik \\
\hline 21 & Hibiscus tiliaceus maroon & $\begin{array}{l}\text { Waru } \\
\text { merah }\end{array}$ & 3 & 2 & 3 & 2 & 62.50 & Baik \\
\hline 22 & Khaya senegalensis & Khaya & 4 & 3 & 3 & 2 & 75.00 & Baik \\
\hline 23 & Kigelia africana & Pohon sosis & 4 & 4 & 3 & 3 & 87.50 & Sangat baik \\
\hline टें 24 & Lagerstroemia indica & Bungur & 3 & 4 & 3 & 2 & 75.00 & Baik \\
\hline 25 & Livistona rotundifolia & $\begin{array}{l}\text { Palem } \\
\text { sadeng }\end{array}$ & 2 & 3 & 3 & 3 & 68.75 & Baik \\
\hline 26 & Maniltoa gemmipara & $\begin{array}{l}\text { Sapu } \\
\text { tangan }\end{array}$ & 3 & 4 & 3 & 2 & 75.00 & Baik \\
\hline 27 & Michelia campaca & Cempaka & 3 & 3 & 3 & 2 & 68.75 & Baik \\
\hline 28 & Mimusop elengi & Tanjung & 3 & 4 & 4 & 3 & 87.50 & Sangat baik \\
\hline 29 & Plumeria alba & $\begin{array}{l}\text { Kamboja } \\
\text { putih }\end{array}$ & 1 & 4 & 1 & 2 & 50.00 & Sedang \\
\hline 30 & Plumeria rubra & $\begin{array}{l}\text { Kamboja } \\
\text { merah }\end{array}$ & 1 & 4 & 1 & 2 & 50.00 & Sedang \\
\hline 31 & Polyathia longifolia & $\begin{array}{l}\text { Glodogan } \\
\text { tiang }\end{array}$ & 4 & 1 & 4 & 3 & 75.00 & Baik \\
\hline 32 & Pometia pinnata & Matoa & 2 & 3 & 2 & 3 & 62.50 & Baik \\
\hline 33 & Pterocarpus indicus & Angsana & 4 & 4 & 3 & 2 & 81.25 & Sangat baik \\
\hline 34 & Roystonea regia & Palem raja & 2 & 3 & 2 & 3 & 62.50 & Baik \\
\hline 35 & Samanea saman & Trembesi & 4 & 4 & 4 & 1 & 81.25 & Sangat baik \\
\hline 36 & Schefflera actinophylla & Wali songo & 3 & 4 & 3 & 4 & 87.50 & Sangat baik \\
\hline 37 & Shorea pinonga & Meranti & 3 & 3 & 3 & 2 & 68.75 & Baik \\
\hline 38 & Spathodea campanulata & Kecrutan & 3 & 3 & 3 & 2 & 68.75 & Baik \\
\hline 39 & Swietenia macrophylia & Mahoni & 4 & 4 & 3 & 2 & 81.25 & Sangat baik \\
\hline 40 & Tabebuia pallida & Tabebuia & 1 & 2 & 2 & 3 & 50.00 & Sedang \\
\hline 41 & Tamarindus indica & Asam jawa & 3 & 4 & 3 & 1 & 68.75 & Baik \\
\hline 42 & Tectona grandis & Jati super & 4 & 3 & 2 & 3 & 75.00 & Baik \\
\hline 43 & Terminalia catappa & Ketapang & 4 & 4 & 3 & 4 & 93.75 & Sangat baik \\
\hline 44 & Thevetia peruviana & Tevetia & 2 & 4 & 3 & 2 & 68.75 & Baik \\
\hline 45 & Veitchia merillii & Palem putri & 1 & 2 & 2 & 2 & 43.75 & Sedang \\
\hline 46 & Wodyetia bifurcate & $\begin{array}{l}\text { Palem ekor } \\
\text { tupai }\end{array}$ & 2 & 3 & 2 & 3 & 62.50 & Baik \\
\hline
\end{tabular}

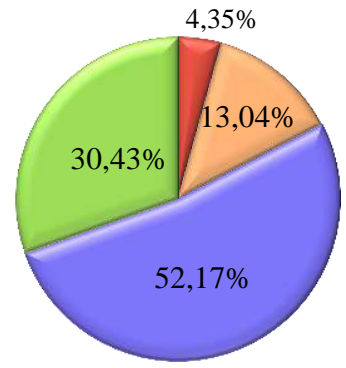

(a)

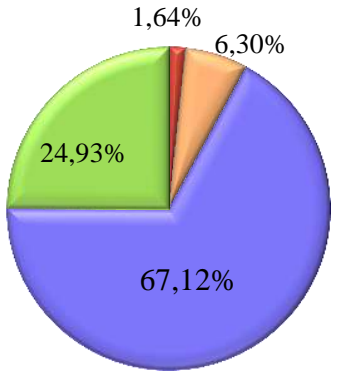

(b)

Gambar 12 Kategori penilaian tanaman Taman Kota 1 BSD dalam fungsi modifikasi suhu (a) persentase jenis tanaman dan (b) persentase total individu tanaman 
Pengukuran suhu udara menunjukkan hasil bahwa rata-rata suhu di dalam Taman Kota 1 BSD lebih rendah dibandingkan dengan suhu di luar taman tersebut dengan selisih rata-rata suhu $1,85^{\circ} \mathrm{C}$ (Tabel 7). Hasil pengukuran suhu di dalam Taman Kota 1 BSD dengan titik pengukuran yang berbeda dapat diketahui bahwa rata-rata suhu pada titik di atas rumput dengan naungan rapat merupakan yang terendah yaitu $29,42^{\circ} \mathrm{C}$, sedangkan rata-rata suhu yang tertinggi $32,01^{\circ} \mathrm{C}$ yaitu di atas perkerasan tanpa naungan.

Perbandingan suhu di titik tanpa naungan dengan titik dengan naungan renggang atau pun rapat terlihat perbedaan yang menunjukkan pada titik pengukuran dengan naungan suhunya lebih rendah dibanding pada titik tanpa naungan. Hal tersebut menunjukkan keefektifan fungsi tanaman dalam memodifikasi suhu.

Tabel 7 Hasil pengukuran suhu udara di Taman Kota 1 BSD

\begin{tabular}{|c|c|c|c|c|c|c|c|c|c|}
\hline \multirow[b]{2}{*}{ Waktu } & \multicolumn{6}{|c|}{ Dalam RTH } & \multirow{2}{*}{$\begin{array}{c}\text { Rata-rata } \\
\text { dalam RTH } \\
\left({ }^{\circ} \mathrm{C}\right)\end{array}$} & \multirow{2}{*}{$\begin{array}{l}\text { Rata-rata } \\
\text { luar RTH } \\
\quad\left({ }^{\circ} \mathrm{C}\right)\end{array}$} & \multirow{2}{*}{$\begin{array}{c}\text { Selisih } \\
\left({ }^{\circ} \mathrm{C}\right)\end{array}$} \\
\hline & $1\left({ }^{\circ} \mathrm{C}\right)$ & $2\left({ }^{\circ} \mathrm{C}\right)$ & $3\left({ }^{\circ} \mathrm{C}\right)$ & $4\left({ }^{\circ} \mathrm{C}\right)$ & $5\left({ }^{\circ} \mathrm{C}\right)$ & $6\left({ }^{\circ} \mathrm{C}\right)$ & & & \\
\hline Pagi & 27.10 & 26.72 & 28.10 & 27.09 & 26.90 & 27.20 & 27.18 & 28.83 & 1.65 \\
\hline Siang & 33.20 & 31.25 & 33.97 & 32.52 & 32.25 & 33.33 & 32.75 & 35.17 & 2.41 \\
\hline Sore & 32.85 & 30.28 & 33.97 & 31.96 & 31.55 & 33.33 & 32.32 & 33.80 & 1.48 \\
\hline Rata-rata & 31.05 & 29.42 & 32.01 & 30.52 & 30.23 & 31.29 & 30.75 & 32.60 & 1.85 \\
\hline
\end{tabular}

Ket : 1: di atas rumput tanpa naungan

2: di atas rumput dengan naungan rapat

3: di atas perkerasan tanpa naungan

4: di atas perkerasan dengan naungan rapat

5: di atas rumput dengan naungan renggang

6: di atas perkerasan dengan naungan renggan

Penilaian aspek fungsi modifikasi suhu pada tanaman di Taman Kota 2 BSD didominasi oleh tanaman berkategori baik dengan persentase terhadap total jenis tanaman 52,5\% dan persentase terhadap total individu 78,95\% (Gambar 13). Pohon Pinus (Pinus merkusii) yang merupakan pohon yang mendominasi di taman tersebut juga termasuk kategori baik dalam penilaian aspek fungsi modifikasi suhu (Tabel 8). Gladiator yang terletak di area plaza juga banyak terdapat pohon Pinus (Pinus merkusii) dan lokasi tersebut menjadi yang disenangi oleh pengunjung.

Tabel 8 Penilaian aspek fungsi modifikasi suhu di Taman Kota 2 BSD

\begin{tabular}{|c|c|c|c|c|c|c|c|c|}
\hline \multirow{2}{*}{ No. } & \multirow{2}{*}{ Nama Ilmiah } & \multirow{2}{*}{$\begin{array}{l}\text { Nama } \\
\text { Lokal }\end{array}$} & \multicolumn{4}{|c|}{ Kriteria fungsi modifikasi suhu } & \multirow{2}{*}{ Skor } & \multirow{2}{*}{ Kategori } \\
\hline & & & K1 & $\mathrm{K} 2$ & K3 & K4 & & \\
\hline 1 & Acacia mangium & Akasia & 4 & 4 & 2 & 2 & 75.00 & Baik \\
\hline 2 & Agathis damara & Damar & 4 & 1 & 4 & 2 & 68.75 & Baik \\
\hline 3 & Alstonia scholaris & Pulai & 3 & 4 & 4 & 4 & 93.75 & $\begin{array}{l}\text { Sangat } \\
\text { baik }\end{array}$ \\
\hline 4 & Artocarpus altilis & Sukun & 4 & 3 & 2 & 4 & 81.25 & $\begin{array}{l}\text { Sangat } \\
\text { baik }\end{array}$ \\
\hline 5 & Bauhinia purpurea & $\begin{array}{l}\text { Pohon } \\
\text { kupu-kupu }\end{array}$ & 2 & 4 & 2 & 2 & 62.50 & Baik \\
\hline 6 & Butia capitata & $\begin{array}{l}\text { Butia } \\
\text { bonnetti }\end{array}$ & 1 & 3 & 2 & 3 & 56.25 & Sedang \\
\hline 7 & $\begin{array}{l}\text { Cassuarina } \\
\text { equisettifolia }\end{array}$ & Cemara & 4 & 2 & 2 & 1 & 56.25 & Sedang \\
\hline 8 & Ceiba pentandra & Kapuk & 4 & 4 & 2 & 2 & 75.00 & Baik \\
\hline 9 & Cerbera odollam & Bintaro & 3 & 4 & 3 & 4 & 87.50 & $\begin{array}{l}\text { Sangat } \\
\text { baik }\end{array}$ \\
\hline
\end{tabular}


Tabel 8 Penilaian aspek fungsi modifikasi suhu di Taman Kota 2 BSD (lanjutan)

\begin{tabular}{|c|c|c|c|c|c|c|c|c|}
\hline \multirow{2}{*}{ No. } & \multirow{2}{*}{ Nama Ilmiah } & \multirow{2}{*}{ Nama Lokal } & \multicolumn{4}{|c|}{ Kriteria fungsi modifikasi suhu } & \multirow{2}{*}{ Skor } & \multirow{2}{*}{ Kategori } \\
\hline & & & $\mathrm{K} 1$ & $\mathrm{~K} 2$ & K3 & K4 & & \\
\hline 10 & $\begin{array}{l}\text { Chrysophyllum } \\
\text { cainito }\end{array}$ & Sawo duren & 3 & 3 & 4 & 3 & 81.25 & $\begin{array}{l}\text { Sangat } \\
\text { baik }\end{array}$ \\
\hline 11 & Delonix regia & Flamboyan & 4 & 4 & 3 & 1 & 75.00 & Baik \\
\hline (2) 12 & Dillenia indica & Sempur & 4 & 4 & 4 & 3 & 93.75 & $\begin{array}{l}\text { Sangat } \\
\text { baik }\end{array}$ \\
\hline दे. & $\begin{array}{l}\text { Dimocarpus } \\
\text { longan }\end{array}$ & Kelengkeng & 3 & 3 & 4 & 4 & 87.50 & $\begin{array}{l}\text { Sangat } \\
\text { baik }\end{array}$ \\
\hline $\begin{array}{l}\vdots 4 \\
\vdots\end{array}$ & $\begin{array}{l}\text { Erythrina } \\
\text { cristagali }\end{array}$ & Dadap merah & 2 & 4 & 2 & 3 & 68.75 & Baik \\
\hline$\approx 15$ & Ficus benjamina & Beringin & 4 & 4 & 3 & 1 & 75.00 & Baik \\
\hline$\frac{1}{8} 16$ & Ficus lyrata & Biola cantik & 4 & 4 & 3 & 4 & 93.75 & $\begin{array}{l}\text { Sangat } \\
\text { baik }\end{array}$ \\
\hline$\underbrace{\infty} 17$ & Filicium depiens & $\begin{array}{l}\text { Kiara } \\
\text { payung }\end{array}$ & 4 & 4 & 4 & 3 & 93.75 & $\begin{array}{l}\text { Sangat } \\
\text { baik }\end{array}$ \\
\hline ऐं 18 & Hevea brasiliensis & Karet & 3 & 3 & 3 & 2 & 68.75 & Baik \\
\hline 19 & Intsia bijuga & Merbau & 4 & 3 & 3 & 3 & 81.25 & $\begin{array}{l}\text { Sangat } \\
\text { baik }\end{array}$ \\
\hline 20 & Khaya antoteca & Khaya & 4 & 3 & 3 & 2 & 75.00 & Baik \\
\hline 21 & Kigelia africa & Pohon Sosis & 4 & 4 & 3 & 3 & 87.50 & $\begin{array}{l}\text { Sangat } \\
\text { baik }\end{array}$ \\
\hline 22 & $\begin{array}{l}\text { Leucaena } \\
\text { leucocephala }\end{array}$ & Lamtoro & 3 & 3 & 1 & 1 & 50.00 & Sedang \\
\hline 23 & Mangifera indica & Mangga & 2 & 4 & 3 & 2 & 68.75 & Baik \\
\hline 24 & $\begin{array}{l}\text { Maniltoa } \\
\text { grandiflora }\end{array}$ & Sapu tangan & 3 & 4 & 3 & 2 & 75.00 & Baik \\
\hline 25 & Mimusop elengi & Tanjung & 3 & 4 & 4 & 3 & 87.50 & $\begin{array}{l}\text { Sangat } \\
\text { baik }\end{array}$ \\
\hline 26 & $\begin{array}{l}\text { Muntingia } \\
\text { calabura }\end{array}$ & Seri & 3 & 4 & 3 & 1 & 68.75 & Baik \\
\hline 27 & $\begin{array}{l}\text { Murraya } \\
\text { paniculata }\end{array}$ & Kemuning & 2 & 3 & 3 & 3 & 68.75 & Baik \\
\hline 28 & $\begin{array}{l}\text { Peronema } \\
\text { canescen }\end{array}$ & Sungkai & 3 & 2 & 4 & 2 & 68.75 & Baik \\
\hline 29 & Pinus merkusii & Pinus & 4 & 3 & 2 & 2 & 68.75 & Baik \\
\hline 30 & Plumeria sp. & Kamboja & 1 & 4 & 1 & 2 & 50.00 & Sedang \\
\hline 31 & $\begin{array}{l}\text { Polyalthia } \\
\text { fragrans }\end{array}$ & $\begin{array}{l}\text { Glodogan } \\
\text { bulat }\end{array}$ & 1 & 4 & 4 & 2 & 68.75 & Baik \\
\hline 32 & Pometia pinnata & Matoa & 2 & 3 & 2 & 3 & 62.50 & Baik \\
\hline 33 & Roystonea regia & Palem raja & 2 & 3 & 2 & 3 & 62.50 & Baik \\
\hline 34 & Samanea saman & Trembesi & 4 & 4 & 4 & 1 & 81.25 & $\begin{array}{l}\text { Sangat } \\
\text { baik }\end{array}$ \\
\hline 35 & Shorea sp. & Meranti & 4 & 3 & 2 & 3 & 75.00 & Baik \\
\hline 36 & $\begin{array}{l}\text { Spatodhea } \\
\text { campanulata }\end{array}$ & Kecrutan & 3 & 3 & 3 & 2 & 68.75 & Baik \\
\hline 37 & $\begin{array}{l}\text { Switenia } \\
\text { macrophylla }\end{array}$ & Mahoni & 4 & 4 & 3 & 2 & 81.25 & $\begin{array}{l}\text { Sangat } \\
\text { baik }\end{array}$ \\
\hline 38 & $\begin{array}{l}\text { Tabebuia } \\
\text { chrysantha }\end{array}$ & Tabebuia & 1 & 2 & 2 & 3 & 50.00 & Sedang \\
\hline 39 & $\begin{array}{l}\text { Terminalia } \\
\text { catappa }\end{array}$ & Ketapang & 4 & 4 & 3 & 4 & 93.75 & Baik \\
\hline 40 & $\begin{array}{l}\text { Terminalia } \\
\text { mantaly }\end{array}$ & $\begin{array}{l}\text { Ketapang } \\
\text { kencana }\end{array}$ & 2 & 2 & 2 & 1 & 43.75 & Sedang \\
\hline
\end{tabular}




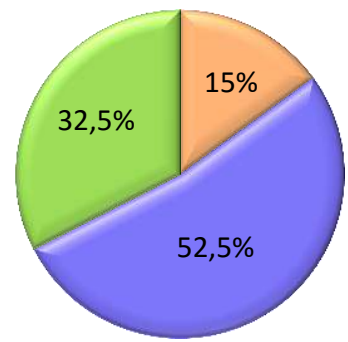

(a)

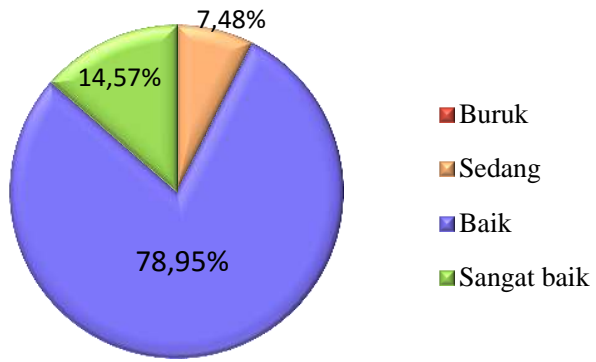

(b)

Gambar 13 Kategori penilaian tanaman Taman Kota 2 BSD dalam fungsi modifikasi suhu (a) persentase jenis tanaman dan (b) persentase total individu tanaman

Hasil pengukuran rata-rata suhu udara di dalam Taman Kota 2 BSD lebih rendah dibandingkan dengan rata-rata suhu di luar taman tersebut dengan selisih rata-rata suhu $1,90^{\circ} \mathrm{C}$ (Tabel 9). Pengukuran suhu yang dilakukan di dalam Taman Kota 2 BSD dengan titik pengukuran yang berbeda menunjukkan bahwa rata-rata suhu pada titik di atas rumput dengan naungan rapat merupakan yang terendah yaitu $29,36^{\circ} \mathrm{C}$, sedangkan rata-rata suhu yang tertinggi $30,73^{\circ} \mathrm{C}$ yaitu di atas perkerasan tanpa naungan.

Perbandingan suhu di titik tanpa naungan dan titik dengan naungan renggang atau pun rapat terlihat perbedaan yang menunjukkan pada titik pengukuran dengan naungan suhunya lebih rendah dibanding pada titik tanpa naungan. Hal tersebut menunjukkan keefektifan fungsi tanaman dalam memodifikasi suhu.

Tabel 9 Hasil pengukuran suhu udara di Taman Kota 2 BSD

\begin{tabular}{lccccccccc}
\hline \multirow{4}{*}{ Waktu } & \multicolumn{4}{c}{ Dalam RTH } & \multicolumn{2}{c}{ Rata-rata } \\
\cline { 2 - 8 } & $1\left({ }^{\circ} \mathrm{C}\right)$ & $2\left({ }^{\circ} \mathrm{C}\right)$ & $3\left({ }^{\circ} \mathrm{C}\right)$ & $4\left({ }^{\circ} \mathrm{C}\right)$ & $5\left({ }^{\circ} \mathrm{C}\right)$ & $6\left({ }^{\circ} \mathrm{C}\right)$ & $\begin{array}{c}\text { Rata-rata } \\
\left({ }^{\circ} \mathrm{C}\right)\end{array}$ & $\begin{array}{c}\text { Sar RTH } \\
\left({ }^{\circ} \mathrm{C}\right)\end{array}$ & $\begin{array}{c}\text { Selisih } \\
\left({ }^{\circ} \mathrm{C}\right)\end{array}$ \\
\hline Pagi & 26.53 & 25.65 & 26.50 & 25.87 & 25.58 & 26.80 & 26.16 & 27.37 & 1.21 \\
Siang & 32.90 & 31.55 & 33.22 & 31.38 & 31.23 & 32.35 & 32.11 & 34.93 & 2.83 \\
Sore & 31.67 & 30.88 & 32.47 & 31.25 & 30.82 & 31.27 & 31.39 & 33.07 & 1.68 \\
Rata-rata & 30.37 & 29.36 & 30.73 & 29.50 & 29.21 & 30.14 & 29.88 & 31.79 & 1.90 \\
\hline
\end{tabular}

Ket : 1: di atas rumput tanpa naungan

2: di atas rumput dengan naungan rapat

3: di atas perkerasan tanpa naungan

4: di atas perkerasan dengan naungan rapat

5: di atas rumput dengan naungan renggang

6: di atas perkerasan dengan naungan renggang

Kedua lokasi penelitian berkategori baik dalam aspek penilaian fungsi modifikasi suhu dengan skor Taman Kota 1 BSD sebesar 315,34 dan Taman Kota 2 BSD sebesar 306.09 (Tabel 10). Selisih rata-rata suhu di dalam Taman Kota 1 BSD dan Taman Kota 2 BSD dengan rata-rata suhu di luar taman masing-masing menunjukkan adanya sedikit perbedaan. Taman Kota 1 BSD terjadi selisih ratarata suhu di dalam dengan di luar sebesar $1,85^{\circ} \mathrm{C}$, sedangkan Taman Kota $2 \mathrm{BSD}$ selisih suhunya sebesar $1,90^{\circ} \mathrm{C}$ (Tabel 11). Hal tersebut menunjukkan bahwa di kedua taman tersebut efektif dalam memberikan fungsi modifikasi suhu udara. 
Tabel 10 Persentase penilaian tanaman fungsi modifikasi suhu

\begin{tabular}{|c|c|c|c|c|c|c|c|}
\hline Lokasi & Kategori & $\begin{array}{c}\text { Jumlah } \\
\text { jenis }\end{array}$ & $\begin{array}{l}\text { Jumlah } \\
\text { individu }\end{array}$ & $\begin{array}{l}\text { Persentase } \\
\text { terhadap total } \\
\text { jenis }(\%)\end{array}$ & $\begin{array}{l}\text { Persentase } \\
\text { terhadap total } \\
\text { individu }(\%)\end{array}$ & $\begin{array}{l}\text { Skor } \\
\text { RTH }\end{array}$ & $\begin{array}{l}\text { Kategori } \\
\text { Skor } \\
\text { RTH }\end{array}$ \\
\hline & Buruk & 2 & 6 & 4.35 & 1.64 & \multirow{5}{*}{315.34} & \multirow{4}{*}{ Baik } \\
\hline Taman Kota 1 & Sedang & 6 & 23 & 13.04 & 6.30 & & \\
\hline BSD & Baik & 24 & 245 & 52.17 & 67.12 & & \\
\hline 5 & Sangat baik & 14 & 91 & 30.43 & 24.93 & & \\
\hline से & Buruk & 0 & 0 & 0 & 0 & & \multirow{4}{*}{ Baik } \\
\hline QTaman Kota 2 & Sedang & 6 & 54 & 15 & 7.48 & \multirow{3}{*}{306.09} & \\
\hline BSD & Baik & 21 & 570 & 52.5 & 78.95 & & \\
\hline$\approx$ & Sangat baik & 13 & 98 & 32.5 & 13.57 & & \\
\hline
\end{tabular}

Tabel 11 Rata-rata suhu udara Taman Kota 1 BSD dan Taman Kota 2 BSD

\begin{tabular}{|c|c|c|c|c|c|c|c|c|c|}
\hline \multirow{2}{*}{ Lokasi } & \multicolumn{6}{|c|}{ Dalam RTH } & \multirow{2}{*}{$\begin{array}{l}\text { Rata-rata suhu } \\
\text { dalam RTH }\left({ }^{\circ} \mathrm{C}\right)\end{array}$} & \multirow{2}{*}{$\begin{array}{l}\text { Rata-rata suhu } \\
\text { luar RTH }\left({ }^{\circ} \mathrm{C}\right)\end{array}$} & \multirow{2}{*}{$\begin{array}{c}\text { Selisih } \\
\left({ }^{\circ} \mathrm{C}\right)\end{array}$} \\
\hline & $1\left({ }^{\circ} \mathrm{C}\right)$ & $2\left({ }^{\circ} \mathrm{C}\right)$ & $3\left({ }^{\circ} \mathrm{C}\right)$ & $4\left({ }^{\circ} \mathrm{C}\right)$ & $5\left({ }^{\circ} \mathrm{C}\right)$ & $6\left({ }^{\circ} \mathrm{C}\right)$ & & & \\
\hline $\begin{array}{l}\text { Taman Kota } 1 \\
\text { BSD }\end{array}$ & 31.05 & 29.42 & 32.01 & 30.52 & 30.23 & 31.29 & 30.75 & 32.60 & 1.85 \\
\hline $\begin{array}{l}\text { Taman Kota } 2 \\
\text { BSD }\end{array}$ & 30.37 & 29.36 & 30.73 & 29.50 & 29.21 & 30.14 & 29.88 & 31.79 & 1.90 \\
\hline
\end{tabular}

Ket : 1: di atas rumput tanpa naungan

2: di atas rumput dengan naungan rapat

3: di atas perkerasan tanpa naungan

4: di atas perkerasan dengan naungan rapat

5: di atas rumput dengan naungan renggang

6: di atas perkerasan dengan naungan renggang

Persepsi responden pengunjung Taman Kota 1 BSD $67 \%$ menyatakan bahwa suhu udara di taman tersebut berada pada tingkat sejuk (Gambar 14). Persepsi responden pengunjung Taman Kota 2 BSD yang menyatakan suhu taman tersebut berada di tingkat sejuk dan sedang sedikit perbedaannya, namun masih lebih banyak yang menyatakan sejuk yaitu sebanyak $47 \%$ dan $43 \%$. Persentase tertinggi lokasi yang dinilai sejuk yaitu pada area pohon rindang (Gambar 15). Hasil persepsi tersebut sebanding dengan hasil pengukuran suhu udara atau pun penilaian fungsi tanaman yang menunjukkan adanya modifikasi suhu di dalam kedua taman tersebut.

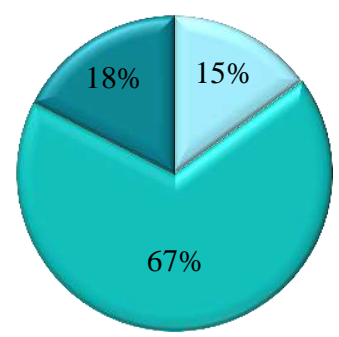

(a)

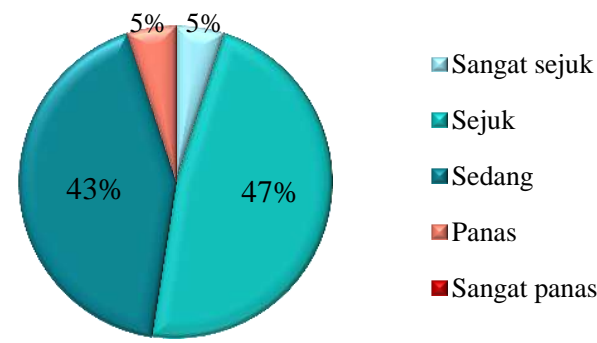

(b)

Gambar 14 Persentase persepsi responden tentang tingkat suhu di (a) Taman Kota 1 BSD dan (b) Taman Kota 2 BSD 


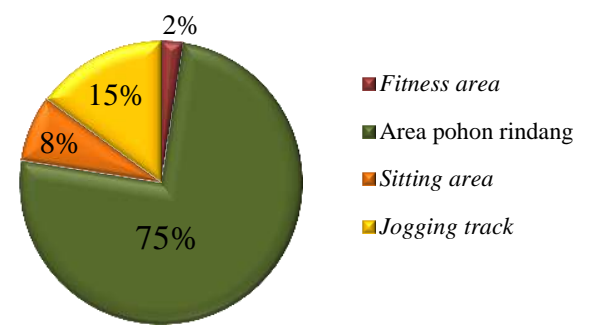

(a)

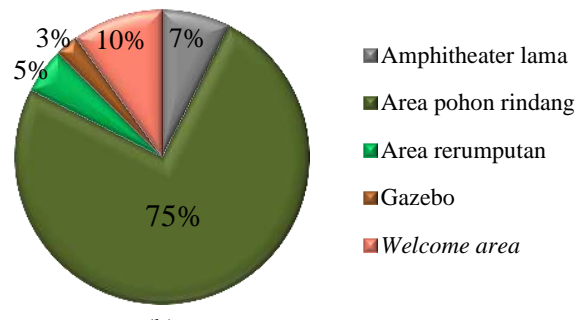

(b)

Gambar 15 Persentase persepsi responden tentang lokasi yang sejuk di (a) Taman Kota 1 BSD dan (b) Taman Kota 2 BSD

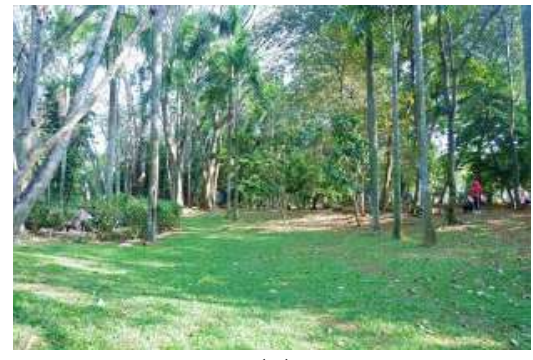

(a)

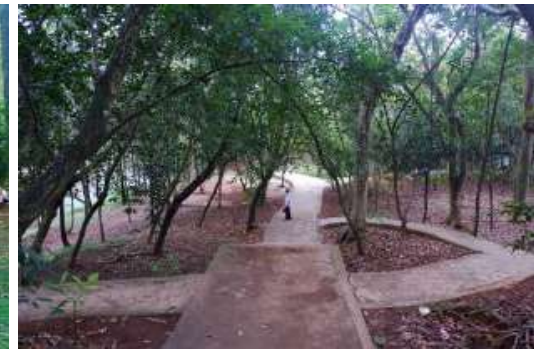

(b)

Gambar 16 Lokasi yang sejuk di (a) area pohon rindang Taman Kota 1 BSD dan (b) area pohon rindang Taman Kota 2 BSD.

\section{Fungsi kontrol kelembaban udara}

Salah satu faktor pembentuk kenyaman thermal selain suhu udara yaitu kelembaban. Kelembaban merupakan jumlah kandungan uap air dalam udara. Menurut Laurie (1986) kelembaban optimal adalah pada kisaran 40-75\%. Tanaman sebagai kontrol kelembaban udara mengatur kandungan uap air di udara dengan melakukan evapotranspirasi.

Berikut adalah kriteria tanaman dengan fungsi kontrol kelembaban udara yang baik:

$\mathrm{K} 1=$ Kerapatan daun rendah (Bianpoen et. Al 1989)

K2 = Berdaun jarum atau kasar (Grey dan Deneke 1978)

K3 = Tekstur batang kasar (Grey dan Deneke 1978)

K4 = Jumlah daun banyak (Carpenter et al. 1975)

Penilaian tanaman di setiap lokasi penelitian terhadap aspek fungsi kontrol kelembaban berdasarkan keempat kriteria tersebut diuraikan dalam masingmasing Tabel 12 dan 14.

Penilaian aspek fungsi kontrol kelembaban pada tanaman di Taman Kota 1 BSD didominasi oleh tanaman berkategori baik dengan persentase terhadap total jenis tanaman $80,43 \%$ dan persentase terhadap total individu 78,08\% (Gambar 17). Tanaman dengan kategori sangat baik tersebar di berbagai area sekitar jogging track sehingga memberikan kenyamanan pada pengunjung ketika berkeliling taman. 
Tabel 12 Penilaian aspek fungsi kontrol kelembaban udara di Taman Kota 1 BSD

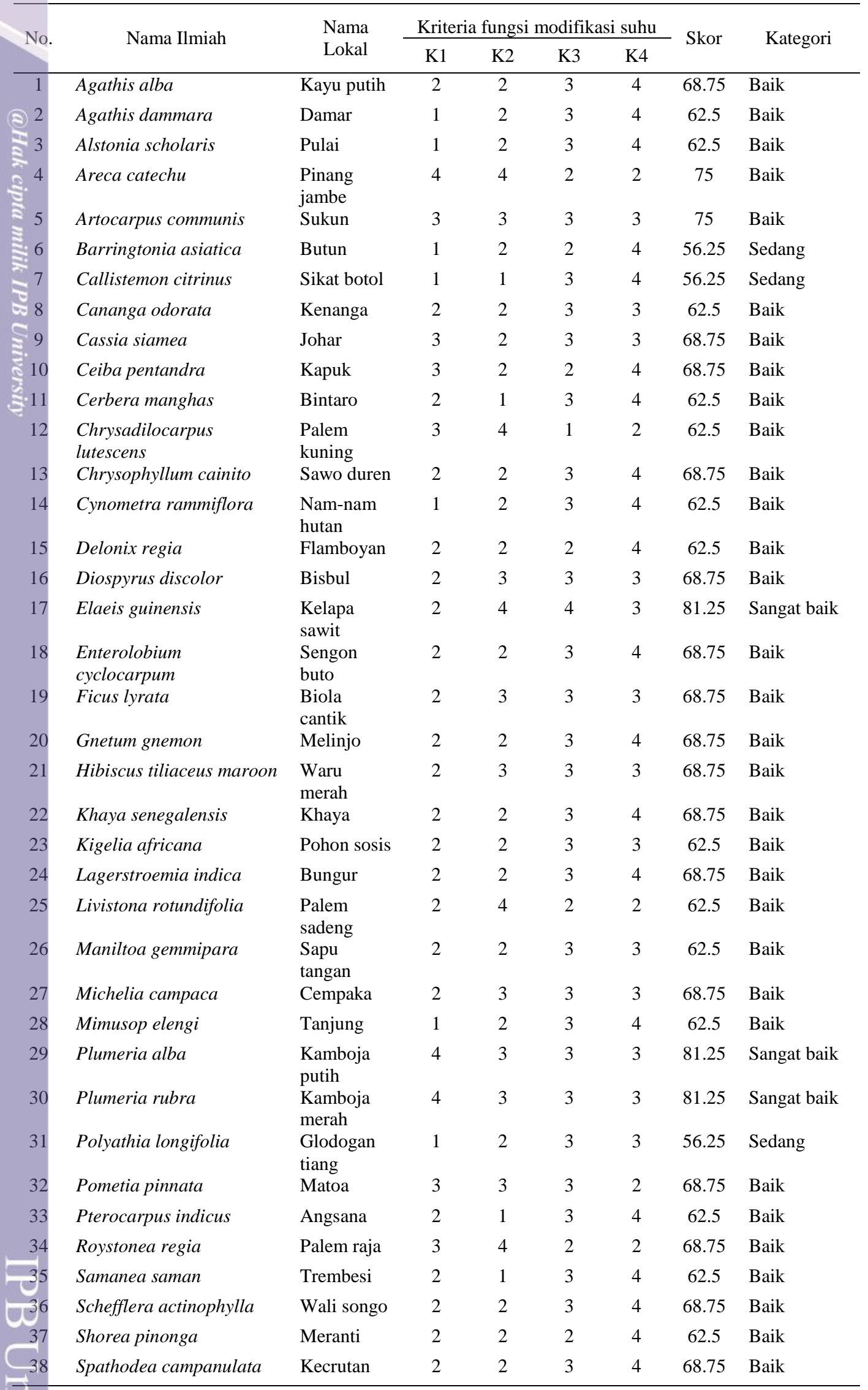


Tabel 12 Penilaian aspek fungsi kontrol kelembaban udara di Taman Kota 1 BSD (lanjutan)

\begin{tabular}{|c|c|c|c|c|c|c|c|c|}
\hline \multirow{2}{*}{ No. } & \multirow{2}{*}{ Nama Ilmiah } & \multirow{2}{*}{$\begin{array}{l}\text { Nama } \\
\text { Lokal }\end{array}$} & \multicolumn{4}{|c|}{ Kriteria fungsi modifikasi suhu } & \multirow{2}{*}{ Skor } & \multirow{2}{*}{ Kategori } \\
\hline & & & $\mathrm{K} 1$ & $\mathrm{~K} 2$ & K3 & K4 & & \\
\hline 39 & Swietenia macrophylia & Mahoni & 2 & 2 & 3 & 3 & 62.5 & Baik \\
\hline 40 & Tabebuia pallida & Tabebuia & 3 & 3 & 2 & 3 & 68.75 & Baik \\
\hline 41 & Tamarindus indica & Asam jawa & 1 & 1 & 3 & 4 & 56.25 & Sedang \\
\hline 42 & Tectona grandis & Jati super & 3 & 2 & 3 & 3 & 68.75 & Baik \\
\hline 43 & Terminalia catappa & Ketapang & 2 & 3 & 3 & 4 & 75 & Baik \\
\hline 44 & Thevetia peruviana & Tevetia & 2 & 4 & 2 & 3 & 68.75 & Baik \\
\hline 45 & Veitchia merillii & Palem putri & 4 & 4 & 2 & 3 & 81.25 & Sangat baik \\
\hline 46 & Wodyetia bifurcate & $\begin{array}{l}\text { Palem ekor } \\
\text { tupai }\end{array}$ & 4 & 4 & 2 & 3 & 81.25 & Sangat baik \\
\hline
\end{tabular}

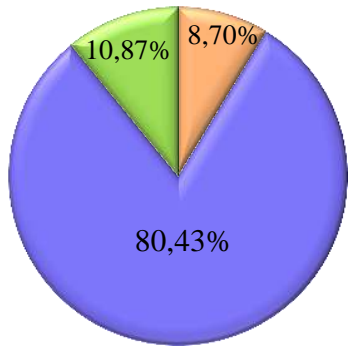

(a)

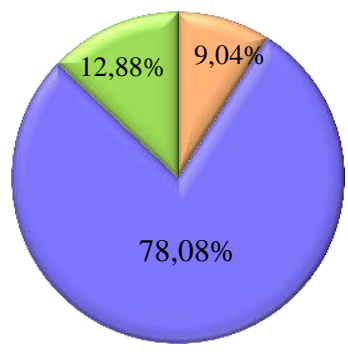

(b)

\section{回Buruk \\ 四 Sedang \\ 口Baik \\ - Sangat baik}

Gambar 17 Kategori penilaian tanaman Taman Kota 1 BSD terhadap aspek fungsi kontrol kelembaban (a) persentase jenis tanaman dan (b) persentase total individu tanaman

Pengukuran kelembaban menunjukkan hasil bahwa rata-rata kelembaban di dalam Taman Kota 1 BSD lebih tinggi dibandingkan dengan kelembaban di luar taman tersebut dengan selisih rata-rata kelembaban 4,40\% (Tabel 13). Hasil pengukuran kelembaban di dalam Taman Kota 1 BSD dengan titik pengukuran yang berbeda dapat diketahui bahwa rata-rata suhu pada titik di atas rumput dengan naungan rapat merupakan yang terendah yaitu $66,56 \%$, sedangkan ratarata kelembaban yang terendah $54,33 \%$ yaitu di atas perkerasan dengan naungan renggang.

Perbandingan kelembaban di titik tanpa naungan dengan titik dengan naungan renggang atau pun rapat terlihat perbedaan yang menunjukkan pada titik pengukuran dengan naungan kelembabannya lebih tinggi dibanding pada titik tanpa naungan. Hal tersebut menunjukkan terjadi kontrol kelembaban dengan adanya tanaman di taman tersebut.

Tabel 13 Hasil pengukuran kelembaban di Taman Kota 1 BSD

\begin{tabular}{|c|c|c|c|c|c|c|c|c|c|}
\hline \multirow{2}{*}{ Waktu } & \multicolumn{6}{|c|}{ Dalam RTH } & \multirow{2}{*}{$\begin{array}{c}\text { Rata-rata } \\
\text { dalam RTH } \\
(\%)\end{array}$} & \multirow{2}{*}{$\begin{array}{c}\text { Rata-rata } \\
\text { luar RTH } \\
(\%)\end{array}$} & \multirow{2}{*}{ Selisih (\%) } \\
\hline & $1(\%)$ & $2(\%)$ & $3(\%)$ & $4(\%)$ & $5(\%)$ & $6(\%)$ & & & \\
\hline Pagi & 74.50 & 74.00 & 66.67 & 69.78 & 72.83 & 69.00 & 71.13 & 70.00 & 1.13 \\
\hline Siang & 51.33 & 61.33 & 49.00 & 55.22 & 56.50 & 46.67 & 53.34 & 45.33 & 8.01 \\
\hline Sore & 52.50 & 64.33 & 50.00 & 59.00 & 55.17 & 47.33 & 54.72 & 50.67 & 4.06 \\
\hline Rata-rata & 59.44 & 66.56 & 55.22 & 61.33 & 61.50 & 54.33 & 59.73 & 55.33 & 4.40 \\
\hline
\end{tabular}


Ket : 1: di atas rumput tanpa naungan

2: di atas rumput dengan naungan rapat

3: di atas perkerasan tanpa naungan

4: di atas perkerasan dengan naungan rapat

5: di atas rumput dengan naungan renggang

6: di atas perkerasan dengan naungan renggang

Penilaian tanaman dalam aspek fungsi kontrol kelembaban di Taman Kota 2 BSD didominasi oleh tanaman berkategori baik dengan persentase terhadap total Genis tanaman $87,50 \%$ dan persentase terhadap total individu 53,74\% (Gambar 18). Pohon Pinus (Pinus merkusii) yang merupakan pohon yang mendominasi di Taman Kota 2 BSD termasuk dalam kategori sangat baik dalam penilaian aspek fungsi kontrol kelembaban(Tabel 14).

Tabel 14 Penilaian aspek fungsi kelembaban di Taman Kota 2 BSD

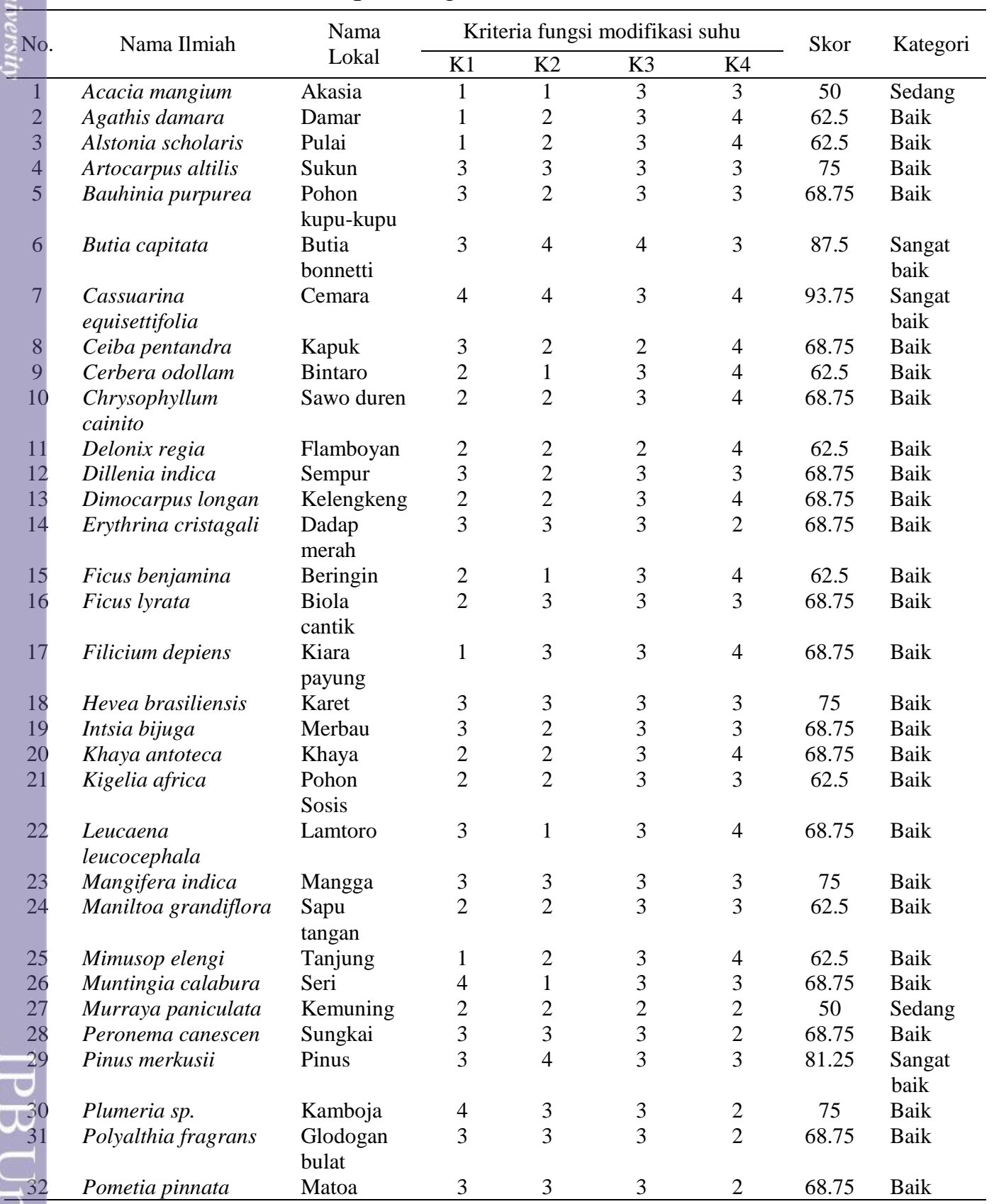


Tabel 14 Penilaian aspek fungsi kelembaban di Taman Kota 2 BSD (lanjutan)

\begin{tabular}{|c|c|c|c|c|c|c|c|c|}
\hline \multirow{2}{*}{ No. } & \multirow{2}{*}{ Nama Ilmiah } & \multirow{2}{*}{$\begin{array}{l}\text { Nama } \\
\text { Lokal }\end{array}$} & \multicolumn{4}{|c|}{ Kriteria fungsi modifikasi suhu } & \multirow{2}{*}{ Skor } & \multirow{2}{*}{ Kategor } \\
\hline & & & K1 & $\mathrm{K} 2$ & K3 & K4 & & \\
\hline 33 & Roystonea regia & Palem raja & 3 & 4 & 2 & 2 & 68.75 & Baik \\
\hline 34 & Samanea saman & Trembesi & 2 & 1 & 3 & 4 & 62.5 & Baik \\
\hline 35 & Shorea sp. & Meranti & 2 & 2 & 2 & 4 & 62.5 & Baik \\
\hline 36 & $\begin{array}{l}\text { Spatodhea } \\
\text { campanulata }\end{array}$ & Kecrutan & 2 & 2 & 3 & 4 & 68.75 & Baik \\
\hline 37 & $\begin{array}{l}\text { Switenia } \\
\text { macrophylla }\end{array}$ & Mahoni & 2 & 2 & 3 & 3 & 62.5 & Baik \\
\hline 38 & Tabebuia chrysantha & Tabebuia & 3 & 3 & 2 & 2 & 62.5 & Baik \\
\hline 39 & Terminalia catappa & Ketapang & 2 & 3 & 3 & 4 & 75 & Baik \\
\hline 40 & Terminalia mantaly & $\begin{array}{l}\text { Ketapang } \\
\text { kencana }\end{array}$ & 4 & 1 & 3 & 3 & 68.75 & Baik \\
\hline
\end{tabular}

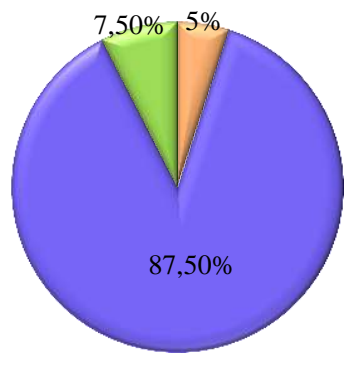

(a)

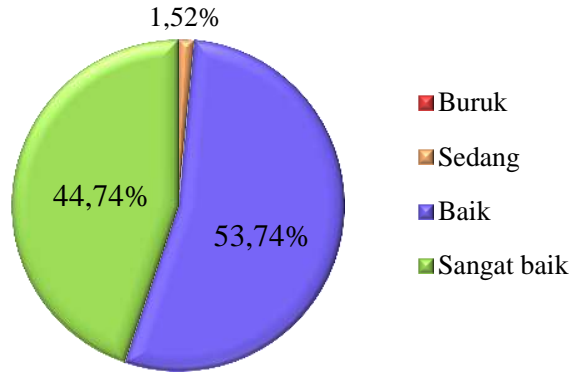

(b)

Gambar 18 Kategori penilaian tanaman Taman Kota 2 BSD terhadap aspek fungsi kontrol kelembaban (a) persentase jenis tanaman dan (b) persentase total individu tanaman

Hasil pengukuran rata-rata kelembaban di dalam Taman Kota 2 BSD lebih tinggi dibandingkan dengan rata-rata kelembaban di luar taman tersebut dengan selisih rata-rata kelembaban 8,96\% (Tabel 15). Pengukuran kelembaban yang dilakukan di dalam Taman Kota 2 BSD dengan titik pengukuran yang berbeda menunjukkan bahwa rata-rata kelembaban pada titik di atas rumput dengan naungan rapat merupakan yang tertinggi yaitu $71,33 \%$, sedangkan rata-rata kelembaban terendah 66,50 yaitu di atas rumput tanpa naungan.

Perbandingan kelembaban di titik tanpa naungan dan titik dengan naungan renggang atau pun rapat terlihat perbedaan yang menunjukkan pada titik pengukuran dengan naungan kelembabannya lebih tinggi dibanding pada titik tanpa naungan. Hal tersebut menunjukkan keefektifan fungsi tanaman pada taman tersebut dalam mengontrol kelembaban.

Tabel 15 Hasil pengukuran kelembaban di Taman Kota 2 BSD

\begin{tabular}{|c|c|c|c|c|c|c|c|c|c|}
\hline \multirow{2}{*}{ Waktu } & \multicolumn{6}{|c|}{ Dalam RTH } & \multirow{2}{*}{$\begin{array}{c}\text { Rata-rata } \\
\text { dalam RTH } \\
(\%)\end{array}$} & \multirow{2}{*}{$\begin{array}{c}\text { Rata-rata } \\
\text { luar RTH } \\
\quad(\%)\end{array}$} & \multirow{2}{*}{ Selisih (\%) } \\
\hline & $1(\%)$ & $2(\%)$ & $3(\%)$ & $4(\%)$ & $5(\%)$ & $6(\%)$ & & & \\
\hline Pagi & 76.67 & 82.50 & 77.67 & 84.67 & 77.83 & 75.50 & 79.14 & 77.67 & 1.47 \\
\hline Siang & 60.50 & 63.83 & 60.83 & 62.17 & 63.83 & 63.00 & 62.36 & 47.00 & 15.36 \\
\hline Sore & 62.33 & 67.67 & 62.33 & 62.83 & 65.83 & 63.33 & 64.06 & 54.00 & 10.06 \\
\hline Rata-rata & 66.50 & 71.33 & 66.94 & 69.89 & 69.17 & 67.28 & 68.52 & 59.56 & 8.96 \\
\hline
\end{tabular}


Ket : 1: di atas rumput tanpa naungan

2: di atas rumput dengan naungan rapat

3: di atas perkerasan tanpa naungan

4: di atas perkerasan dengan naungan rapat

5: di atas rumput dengan naungan renggang

6: di atas perkerasan dengan naungan renggang

Kedua lokasi penelitian berkategori baik dalam aspek penilaian fungsi kontrol kelembaban dengan skor Taman Kota 1 BSD sebesar 303,84 dan Taman Kota 2 BSD sebesar 343,21 (Tabel 16).

Tabel 16 Persentase penilaian tanaman fungsi kontrol kelembaban

\begin{tabular}{|c|c|c|c|c|c|c|c|}
\hline Lokasi & Kategori & $\begin{array}{c}\text { Jumlah } \\
\text { jenis }\end{array}$ & $\begin{array}{c}\text { Jumlah } \\
\text { individu }\end{array}$ & $\begin{array}{l}\text { Persentase } \\
\text { terhadap total } \\
\text { jenis }(\%)\end{array}$ & $\begin{array}{l}\text { Persentase } \\
\text { terhadap total } \\
\text { individu (\%) }\end{array}$ & $\begin{array}{l}\text { Skor } \\
\text { RTH }\end{array}$ & $\begin{array}{c}\text { Kategori } \\
\text { Skor } \\
\text { RTH }\end{array}$ \\
\hline & Buruk & 0 & 0 & 0 & 0 & \multirow{4}{*}{303.84} & \multirow{4}{*}{ Baik } \\
\hline Taman & Sedang & 4 & 33 & 8.70 & 9.04 & & \\
\hline Kota 1 & Baik & 37 & 285 & 80.43 & 78.08 & & \\
\hline BSD & $\begin{array}{l}\text { Sangat } \\
\text { baik }\end{array}$ & 5 & 47 & 10.87 & 12.88 & & \\
\hline & Buruk & 0 & 0 & 0 & 0 & \multirow{4}{*}{343.21} & \multirow{4}{*}{ Baik } \\
\hline Taman & Sedang & 2 & 11 & 5.00 & 1.52 & & \\
\hline Kota 2 & Baik & 35 & 388 & 87.50 & 53.74 & & \\
\hline BSD & $\begin{array}{l}\text { Sangat } \\
\text { baik }\end{array}$ & 3 & 323 & 7.50 & 44.74 & & \\
\hline
\end{tabular}

Perbandingan selisih rata-rata kelembaban di dalam Taman Kota 1 BSD dan Taman Kota 2 BSD dengan rata-rata kelembaban di luar taman masing-masing terlihat perbedaannya. Taman Kota 1 BSD terjadi selisih rata-rata kelembaban di dalam dengan di luar sebesar 4,40\%, sedangkan Taman Kota 2 BSD selisih ratarata kelembabannya sebesar $8,96 \%$ (Tabel 17 ).

Tabel 17 Rata-rata kelembaban Taman Kota 1 BSD dan Taman Kota 2 BSD

\begin{tabular}{|c|c|c|c|c|c|c|c|c|c|}
\hline \multirow{2}{*}{ Lokasi } & \multicolumn{6}{|c|}{ Dalam RTH } & \multirow{2}{*}{$\begin{array}{c}\text { Rata-rata } \\
\text { dalam RTH } \\
(\%)\end{array}$} & \multirow{2}{*}{$\begin{array}{c}\text { Rata-rata } \\
\text { luar RTH } \\
\quad(\%)\end{array}$} & \multirow{2}{*}{ Selisih $(\%$} \\
\hline & $1(\%)$ & $2(\%)$ & $3(\%)$ & $4(\%)$ & $1(\%)$ & $2(\%)$ & & & \\
\hline $\begin{array}{l}\text { Taman } \\
\text { Kota } 1 \\
\text { BSD }\end{array}$ & 59.44 & 66.56 & 55.22 & 61.33 & 61.50 & 54.33 & 59.73 & 55.33 & 4.40 \\
\hline $\begin{array}{l}\text { Taman } \\
\text { Kota } 2 \\
\text { BSD }\end{array}$ & 66.50 & 71.33 & 66.94 & 69.89 & 69.17 & 67.28 & 68.52 & 59.56 & 8.96 \\
\hline
\end{tabular}

Ket : 1: di atas rumput tanpa naungan

2: di atas rumput dengan naungan rapat

3: di atas perkerasan tanpa naungan

4: di atas perkerasan dengan naungan rapat

5: di atas rumput dengan naungan renggang

6: di atas perkerasan dengan naungan renggang

Perbedaan kelembaban yang ditunjukkan dari hasil penilaian fungsi tanaman serta pengukuran di dalam dan di luar kedua taman tersebut menunjukkan bahwa kedua taman memberikan fungsi dalam menaikkan tingkat kelembaban.

Persepsi responden kedua taman persentase terbesarnya menunjukkan penilaian kelembaban berada pada tingkat sedang yaitu tidak terlalu lembab dan terlalu kering. Persepsi responden pengunjung Taman Kota 1 BSD sebanyak 73\% 
menyatakan kelembaban pada tingkat sedang, sedangkan persepsi yang menyatakan taman kota tersebut berada pada tingkat lembab sebanyak $22 \%$ (Gambar 19). Persepsi responden pengunjung Taman Kota 2 BSD yang menyatakan kelembaban taman tersebut berada di tingkat sedang sebanyak $60 \%$ dan persepsi yang menyatakan lembab sebanyak 35\%. Persentase tertinggi lokasi yang dinilai lembab yaitu pada area pohon rindang (Gambar 20). Hasil persepsi tersebut sebanding dengan hasil pengukuran suhu udara atau pun penilaian fungsi tanaman yang menunjukkan efektifitas kedua taman tersebut dalam mengontrol kelembaban.

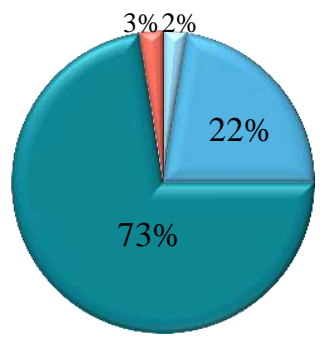

(a)

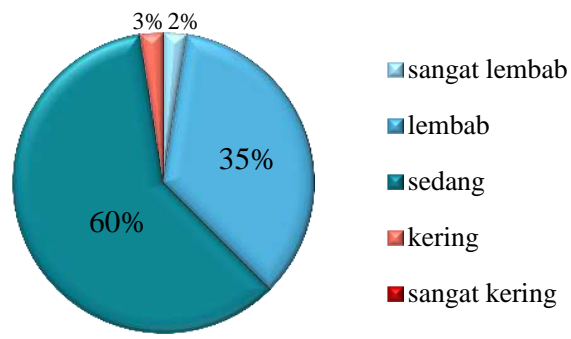

(b)

Gambar 19 Persentase persepsi responden tentang tingkat kelembaban di (a)Taman Kota 1 BSD dan (b) Taman Kota 2 BSD

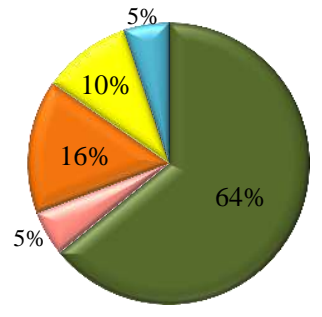

(a)

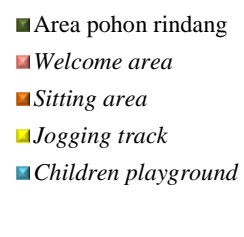

回Welcom

Jogging track 口Children playground

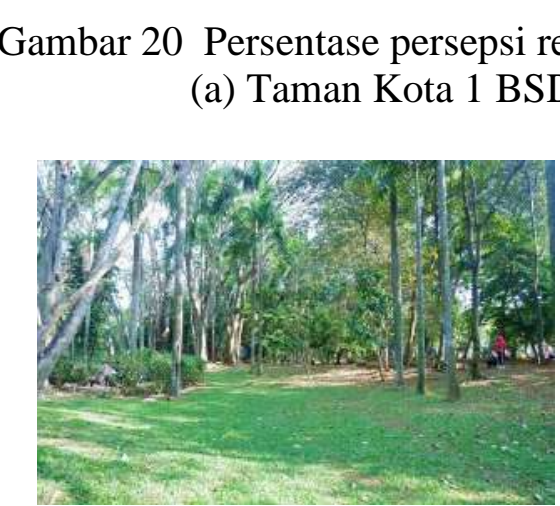

(a)

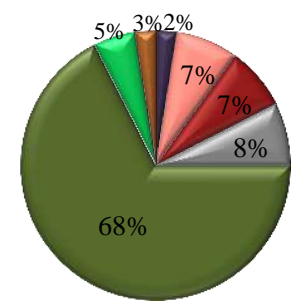

(b)

\author{
Area parkir \\ ⿶Welcome area \\ Dembatan merah \\ amphitheater lama \\ area pohon rindang \\ Q Area rerumputan \\ aGazebo
}

Gambar 20 Persentase persepsi responden tentang lokasi yang lembab di (a) Taman Kota 1 BSD dan (b) Taman Kota 2 BSD

Gambar 21 Lokasi yang lembab di (a) area pohon rindang Taman Kota 1 BSD dan (b) area pohon rindang Taman Kota 2 BSD

\section{Fungsi Penahan Angin}

Angin menjadi faktor pelengkap dalam membentuk ameliorasi iklim mikro di suatu lingkungan. Menurut Fathy (1986) dalam Saputro (2010), angin menyebabkan tingkat kelembaban udara menurun. Angin yang melalui lingkungan bersuhu tinggi juga dapat memberi kenyamanan dengan penguapan 
pendinginan (Grey dan Daneke 1978). Angin juga dapat menimbulkan kerusakan sehingga tanaman sangat penting perannya dalam mengatur alur dan laju angin.

Berikut adalah kriteria tanaman penahan angin:

K1 = Tanaman tinggi (Carpenter et al. 1975)

K2 = Daunnya tidak mudah gugur (Dahlan 1992)

K3 = Massa daun rapat (DPU Dirjen Bina Marga 1996)

K4 = Berdaun tebal (DPU Dirjen Bina Marga 1996)

Hasil penilaian tanaman terhadap fungsi penahan angin di ketiga lokasi penelitian dipaparkan ke dalam masing-masing Tabel 18 dan 19.

Penilaian aspek fungsi penahan angin di Taman Kota 1 BSD didominasi oleh tanaman berkategori baik dengan persentase terhadap total jenis tanaman $65,22 \%$ dan $72,88 \%$ dari total individu (Gambar 22). Palem raja (Roystonea regia) yang merupakan jenis tanaman dengan jumlah terbanyak di Taman Kota 1 BSD juga termasuk kategori baik dalam aspek fungsi penahan angin (Tabel 18). Hembusan angin pada lokasi yang banyak terdapat Palem raja (Roystonea regia) menjadi terasa lebih kencang.

Tabel 18 Penilaian aspek fungsi penahan angin di Taman Kota 1 BSD

\begin{tabular}{|c|c|c|c|c|c|c|c|c|}
\hline \multirow[t]{2}{*}{ No. } & \multirow[t]{2}{*}{ Nama Ilmiah } & \multirow[t]{2}{*}{ Nama Lokal } & \multicolumn{4}{|c|}{$\begin{array}{l}\text { Kriteria fungsi modifikasi } \\
\text { suhu }\end{array}$} & \multirow[t]{2}{*}{ Skor } & \multirow[t]{2}{*}{ Kategori } \\
\hline & & & K1 & $\mathrm{K} 2$ & K3 & K4 & & \\
\hline 1 & Agathis alba & Kayu putih & 3 & 3 & 3 & 1 & 62.50 & Baik \\
\hline 2 & Agathis dammara & Damar & 4 & 3 & 4 & 2 & 81.25 & Sangat baik \\
\hline 3 & Alstonia scholaris & Pulai & 4 & 2 & 4 & 4 & 87.50 & Sangat baik \\
\hline 4 & Areca catechu & Pinang jambe & 3 & 3 & 1 & 2 & 56.25 & Sedang \\
\hline 5 & Artocarpus communis & Sukun & 4 & 2 & 2 & 4 & 75.00 & Baik \\
\hline 6 & Barringtonia asiatica & Butun & 4 & 2 & 4 & 3 & 81.25 & Sangat baik \\
\hline 7 & Callistemon citrinus & Sikat botol & 3 & 2 & 4 & 1 & 62.50 & Baik \\
\hline 8 & Cananga odorata & Kenanga & 3 & 2 & 3 & 2 & 62.50 & Baik \\
\hline 9 & Cassia siamea & Johar & 4 & 2 & 2 & 1 & 56.25 & Sedang \\
\hline 10 & Ceiba pentandra & Kapuk & 4 & 3 & 2 & 2 & 68.75 & Baik \\
\hline 11 & Cerbera manghas & Bintaro & 3 & 2 & 3 & 4 & 75.00 & Baik \\
\hline 12 & $\begin{array}{l}\text { Chrysadilocarpus } \\
\text { lutescens }\end{array}$ & Palem kuning & 2 & 3 & 2 & 2 & 56.25 & Sedang \\
\hline 13 & Chrysophyllum cainito & Sawo duren & 3 & 2 & 4 & 3 & 75.00 & Baik \\
\hline 14 & Cynometra rammiflora & $\begin{array}{l}\text { Nam-nam } \\
\text { hutan }\end{array}$ & 3 & 2 & 4 & 3 & 75.00 & Baik \\
\hline 15 & Delonix regia & Flamboyan & 4 & 4 & 3 & 1 & 75.00 & Baik \\
\hline 16 & Diospyrus discolor & Bisbul & 3 & 2 & 3 & 2 & 62.50 & Baik \\
\hline 17 & Elaeis guinensis & Kelapa sawit & 2 & 3 & 3 & 2 & 62.50 & Baik \\
\hline 18 & $\begin{array}{l}\text { Enterolobium } \\
\text { cyclocarpum }\end{array}$ & Sengon buto & 4 & 2 & 3 & 1 & 62.50 & Baik \\
\hline 19 & Ficus lyrata & Biola cantik & 3 & 3 & 3 & 4 & 81.25 & Sangat baik \\
\hline 20 & Gnetum gnemon & Melinjo & 3 & 2 & 3 & 3 & 68.75 & Baik \\
\hline 21 & Hibiscus tiliaceus maroon & Waru merah & 2 & 2 & 3 & 2 & 56.25 & Sedang \\
\hline 22 & Khaya senegalensis & Khaya & 4 & 3 & 3 & 2 & 75.00 & Baik \\
\hline 23 & Kigelia africana & Pohon sosis & 3 & 2 & 3 & 3 & 68.75 & Baik \\
\hline 24 & Lagerstroemia indica & Bungur & 3 & 3 & 3 & 2 & 68.75 & Baik \\
\hline 25 & Livistona rotundifolia & Palem sadeng & 4 & 2 & 3 & 3 & 75.00 & Baik \\
\hline 26 & Maniltoa gemmipara & Sapu tangan & 3 & 2 & 3 & 2 & 62.50 & Baik \\
\hline 27 & Michelia campaca & Cempaka & 2 & 2 & 3 & 2 & 56.25 & Sedang \\
\hline 28 & Mimusop elengi & Tanjung & 3 & 3 & 4 & 3 & 81.25 & Sangat baik \\
\hline 29 & Plumeria alba & $\begin{array}{l}\text { Kamboja } \\
\text { putih }\end{array}$ & 3 & 2 & 1 & 2 & 50.00 & Sedang \\
\hline 30 & Plumeria rubra & $\begin{array}{l}\text { Kamboja } \\
\text { merah }\end{array}$ & 3 & 2 & 1 & 2 & 50.00 & Sedang \\
\hline
\end{tabular}


Tabel 18 Penilaian aspek fungsi penahan angin di Taman Kota 1 BSD (lanjutan)

\begin{tabular}{|c|c|c|c|c|c|c|c|c|}
\hline \multirow{2}{*}{ No. } & \multirow{2}{*}{ Nama Ilmiah } & \multirow{2}{*}{$\begin{array}{l}\text { Nama } \\
\text { Lokal }\end{array}$} & \multicolumn{4}{|c|}{ Kriteria fungsi modifikasi suhu } & \multirow{2}{*}{ Skor } & \multirow{2}{*}{ Kategori } \\
\hline & & & $\mathrm{K} 1$ & $\mathrm{~K} 2$ & K3 & $\mathrm{K} 4$ & & \\
\hline 31 & Polyathia longifolia & $\begin{array}{l}\text { Glodogan } \\
\text { tiang }\end{array}$ & 4 & 2 & 4 & 3 & 81.25 & Sangat baik \\
\hline 32 & Pometia pinnata & Matoa & 3 & 2 & 2 & 3 & 62.50 & Baik \\
\hline 33 & Pterocarpus indicus & Angsana & 4 & 3 & 3 & 2 & 75.00 & Baik \\
\hline 34 & Roystonea regia & Palem raja & 4 & 2 & 2 & 3 & 68.75 & Baik \\
\hline 35 & Samanea saman & Trembesi & 3 & 3 & 4 & 1 & 68.75 & Baik \\
\hline 36 & Schefflera actinophylla & Wali songo & 3 & 2 & 3 & 4 & 75.00 & Baik \\
\hline 37 & Shorea pinonga & Meranti & 4 & 3 & 3 & 2 & 75.00 & Baik \\
\hline 38 & Spathodea campanulata & Kecrutan & 4 & 3 & 3 & 2 & 75.00 & Baik \\
\hline 39 & Swietenia macrophylia & Mahoni & 4 & 2 & 3 & 2 & 68.75 & Baik \\
\hline 40 & Tabebuia pallida & Tabebuia & 3 & 2 & 2 & 3 & 62.50 & Baik \\
\hline 41 & Tamarindus indica & Asam jawa & 3 & 3 & 3 & 1 & 62.50 & Baik \\
\hline 42 & Tectona grandis & Jati super & 4 & 3 & 2 & 3 & 75.00 & Baik \\
\hline 43 & Terminalia catappa & Ketapang & 4 & 2 & 3 & 4 & 81.25 & Sangat baik \\
\hline 44 & Thevetia peruviana & Tevetia & 2 & 2 & 3 & 2 & 56.25 & Sedang \\
\hline 45 & Veitchia merillii & Palem putri & 2 & 2 & 2 & 2 & 50.00 & Sedang \\
\hline 46 & Wodyetia bifurcate & $\begin{array}{l}\text { Palem ekor } \\
\text { tupai }\end{array}$ & 3 & 2 & 2 & 3 & 62.50 & Baik \\
\hline
\end{tabular}

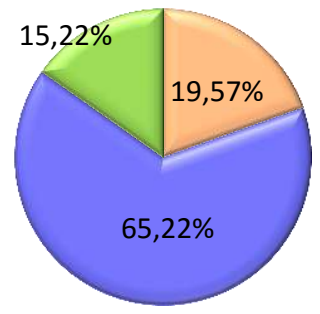

(a)

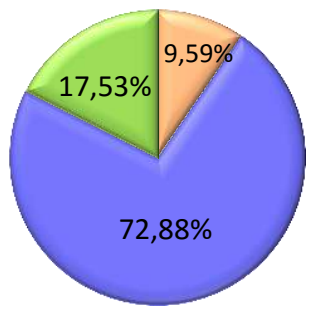

(b)
Buruk

$\square$ Sedang

口Baik

$\square$ Sangat baik

Gambar 22 Kategori penilaian tanaman di Taman Kota 1 BSD terhadap aspek fungsi penahan angin (a) persentase jenis tanaman dan (b) persentase total individu tanaman

Hasil dari persepsi pengunjung Taman Kota 1 BSD sebagian besar menyatakan hembusan angin di taman tersebut terasa sedang (Gambar 23). Persepsi pengunjung menunjukkan bahwa lokasi di taman tersebut yang hembusan anginnya paling terasa adalah area pohon rindang (Gambar 24). Lokasi urutan berikutnya yang terasa hembusan angin adalah sitting area.

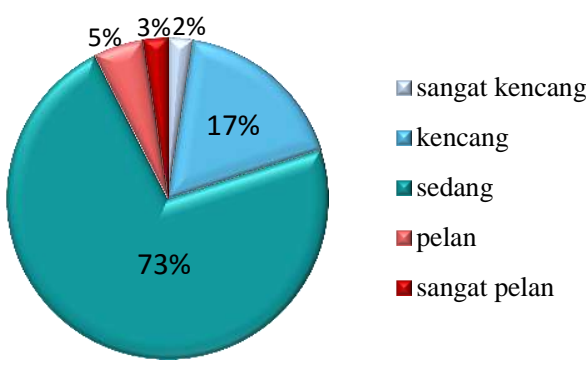

Gambar 23 Persentase persepsi responden tentang tingkat kecepatan angin di Taman Kota 1 BSD 


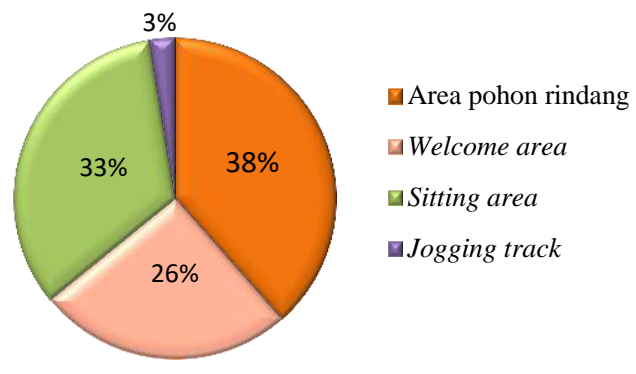

Gambar 24 Persentase persepsi responden tentang lokasi yang terasa hembusan angin di Taman Kota 1 BSD

Penilaian aspek fungsi penahan angin di Taman Kota 2 BSD didominasi oleh tanaman berkategori baik dengan persentase terhadap total jenis tanaman $60 \%$ dan $82 \%$ dari total individu (Gambar 25). Pinus (Pinus merkusii) yang merupakan jenis tanaman yang mendominasi di Taman Kota 2 BSD juga termasuk kategori baik dalam aspek fungsi penahan angin (Tabel 19).

Tabel 19 Penilaian aspek fungsi penahan angin di Taman Kota 2 BSD

\begin{tabular}{|c|c|c|c|c|c|c|c|c|}
\hline \multirow{2}{*}{ No. } & \multirow{2}{*}{ Nama Ilmiah } & \multirow{2}{*}{ Nama Lokal } & \multicolumn{4}{|c|}{ Kriteria fungsi modifikasi suhu } & \multirow{2}{*}{ Skor } & \multirow{2}{*}{ Kategori } \\
\hline & & & K1 & $\mathrm{K} 2$ & K3 & K4 & & \\
\hline 1 & Acacia mangium & Akasia & 4 & 2 & 2 & 2 & 62.50 & Baik \\
\hline 2 & Agathis damara & Damar & 4 & 3 & 4 & 2 & 81.25 & $\begin{array}{l}\text { Sangat } \\
\text { baik }\end{array}$ \\
\hline 3 & Alstonia scholaris & Pulai & 4 & 2 & 4 & 4 & 87.50 & $\begin{array}{l}\text { Sangat } \\
\text { baik }\end{array}$ \\
\hline 4 & Artocarpus altilis & Sukun & 4 & 2 & 2 & 4 & 75.00 & Baik \\
\hline 5 & Bauhinia purpurea & $\begin{array}{l}\text { Pohon kupu- } \\
\text { kupu }\end{array}$ & 3 & 3 & 2 & 2 & 62.50 & Baik \\
\hline 6 & Butia capitata & $\begin{array}{l}\text { Butia } \\
\text { bonnetti }\end{array}$ & 2 & 3 & 2 & 3 & 62.50 & Baik \\
\hline 7 & $\begin{array}{l}\text { Cassuarina } \\
\text { equisettifolia }\end{array}$ & Cemara & 4 & 2 & 2 & 1 & 56.25 & Sedang \\
\hline 8 & Ceiba pentandra & Kapuk & 4 & 3 & 2 & 2 & 68.75 & Baik \\
\hline 9 & Cerbera odollam & Bintaro & 3 & 2 & 3 & 4 & 75.00 & Baik \\
\hline 10 & $\begin{array}{l}\text { Chrysophyllum } \\
\text { cainito }\end{array}$ & Sawo duren & 3 & 2 & 4 & 3 & 75.00 & Baik \\
\hline 11 & Delonix regia & Flamboyan & 4 & 4 & 3 & 1 & 75.00 & Baik \\
\hline 12 & Dillenia indica & Sempur & 2 & 3 & 4 & 3 & 75.00 & Baik \\
\hline 13 & $\begin{array}{l}\text { Dimocarpus } \\
\text { longan }\end{array}$ & Kelengkeng & 3 & 3 & 4 & 4 & 87.50 & $\begin{array}{l}\text { Sangat } \\
\text { baik }\end{array}$ \\
\hline 14 & $\begin{array}{l}\text { Erythrina } \\
\text { cristagali }\end{array}$ & Dadap merah & 2 & 2 & 2 & 3 & 56.25 & Sedang \\
\hline 15 & Ficus benjamina & Beringin & 4 & 1 & 3 & 1 & 56.25 & Sedang \\
\hline 16 & Ficus lyrata & Biola cantik & 3 & 3 & 3 & 4 & 81.25 & $\begin{array}{l}\text { Sangat } \\
\text { baik }\end{array}$ \\
\hline 17 & Filicium depiens & $\begin{array}{l}\text { Kiara } \\
\text { payung }\end{array}$ & 3 & 4 & 4 & 3 & 87.50 & $\begin{array}{l}\text { Sangat } \\
\text { baik }\end{array}$ \\
\hline 18 & Hevea brasiliensis & Karet & 3 & 2 & 3 & 2 & 62.50 & Baik \\
\hline 19 & Intsia bijuga & Merbau & 4 & 2 & 3 & 3 & 75.00 & Baik \\
\hline 20 & Khaya antoteca & Khaya & 4 & 3 & 3 & 2 & 75.00 & Baik \\
\hline 21 & Kigelia africa & Pohon Sosis & 3 & 2 & 3 & 3 & 68.75 & Baik \\
\hline 22 & $\begin{array}{l}\text { Leucaena } \\
\text { leucocephala }\end{array}$ & Lamtoro & 3 & 2 & 1 & 1 & 43.75 & Sedang \\
\hline 23 & Mangifera indica & Mangga & 3 & 2 & 3 & 2 & 62.50 & Baik \\
\hline
\end{tabular}


Tabel 19 Penilaian aspek fungsi penahan angin di Taman Kota 2 BSD (lanjutan)

\begin{tabular}{|c|c|c|c|c|c|c|c|c|}
\hline \multirow{2}{*}{ No. } & \multirow{2}{*}{ Nama Ilmiah } & \multirow{2}{*}{ Nama Lokal } & \multicolumn{4}{|c|}{ Kriteria fungsi modifikasi suhu } & \multirow{2}{*}{ Skor } & \multirow{2}{*}{ Kategori } \\
\hline & & & K1 & K2 & K3 & K4 & & \\
\hline 24 & $\begin{array}{l}\text { Maniltoa } \\
\text { grandiflora }\end{array}$ & Sapu tangan & 3 & 2 & 3 & 2 & 62.50 & Baik \\
\hline 25 & Mimusop elengi & Tanjung & 3 & 3 & 4 & 3 & 81.25 & $\begin{array}{l}\text { Sangat } \\
\text { baik }\end{array}$ \\
\hline 26 & $\begin{array}{l}\text { Muntingia } \\
\text { calabura }\end{array}$ & Seri & 3 & 1 & 3 & 1 & 50.00 & Sedang \\
\hline 27 & $\begin{array}{l}\text { Murraya } \\
\text { paniculata }\end{array}$ & Kemuning & 1 & 2 & 3 & 3 & 56.25 & Sedang \\
\hline 28 & $\begin{array}{l}\text { Peronema } \\
\text { canescen }\end{array}$ & Sungkai & 3 & 3 & 4 & 2 & 75.00 & Baik \\
\hline 29 & Pinus merkusii & Pinus & 4 & 2 & 2 & 2 & 62.50 & Baik \\
\hline 30 & Plumeria sp. & Kamboja & 3 & 2 & 1 & 2 & 50.00 & Sedang \\
\hline 31 & $\begin{array}{l}\text { Polyalthia } \\
\text { fragrans }\end{array}$ & $\begin{array}{l}\text { Glodogan } \\
\text { bulat }\end{array}$ & 2 & 3 & 4 & 2 & 68.75 & Baik \\
\hline 32 & Pometia pinnata & Matoa & 3 & 2 & 2 & 3 & 62.50 & Baik \\
\hline 33 & Roystonea regia & Palem raja & 4 & 2 & 2 & 3 & 68.75 & Baik \\
\hline 34 & Samanea saman & Trembesi & 3 & 3 & 4 & 1 & 68.75 & Baik \\
\hline 35 & Shorea sp. & Meranti & 4 & 3 & 3 & 2 & 75.00 & Baik \\
\hline 36 & $\begin{array}{l}\text { Spatodhea } \\
\text { campanulata }\end{array}$ & Kecrutan & 4 & 3 & 3 & 2 & 75.00 & Baik \\
\hline 37 & $\begin{array}{l}\text { Switenia } \\
\text { macrophylla }\end{array}$ & Mahoni & 4 & 2 & 3 & 2 & 68.75 & Baik \\
\hline 38 & $\begin{array}{l}\text { Tabebuia } \\
\text { chrysantha }\end{array}$ & Tabebuia & 2 & 2 & 2 & 3 & 56.25 & Sedang \\
\hline 39 & $\begin{array}{l}\text { Terminalia } \\
\text { catappa }\end{array}$ & Ketapang & 4 & 2 & 3 & 4 & 81.25 & $\begin{array}{l}\text { Sangat } \\
\text { baik }\end{array}$ \\
\hline 40 & $\begin{array}{l}\text { Terminalia } \\
\text { mantaly }\end{array}$ & $\begin{array}{l}\text { Ketapang } \\
\text { kencana }\end{array}$ & 2 & 2 & 2 & 1 & 43.75 & Sedang \\
\hline
\end{tabular}

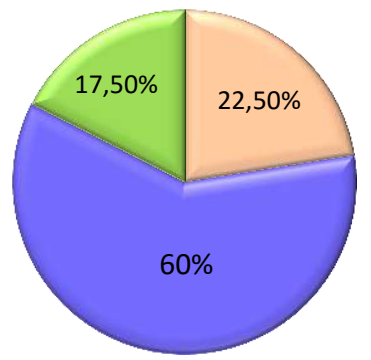

(a)

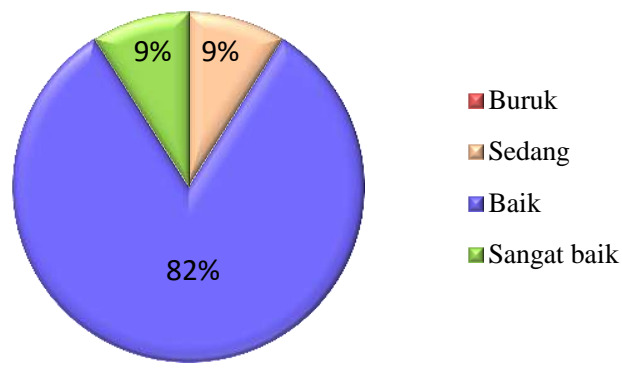

(b)

Gambar 25 Kategori penilaian tanaman Taman Kota 2 BSD terhadap aspek fungsi penahan angin (a) persentase jenis tanaman dan (b) persentase total individu tanaman

Persepsi pengunjung Taman Kota 2 BSD sebagian besar menyatakan hembusan angin di taman tersebut terasa sedang (Gambar 26). Persepsi pengunjung menunjukkan bahwa lokasi di Taman Kota 2 BSD yang hembusan anginnya paling terasa adalah area plaza (Gambar 27). Area plaza terdapat banyak pohon Pinus (Pinus Merkusii) yang termasuk berkategori baik dalam aspek fungsi sebagai penahan angin. 


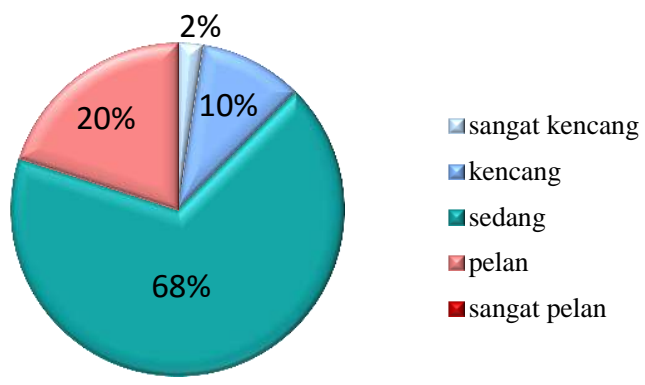

Gambar 26 Persentase persepsi responden tentang tingkat kecepatan angin di Taman Kota 2 BSD

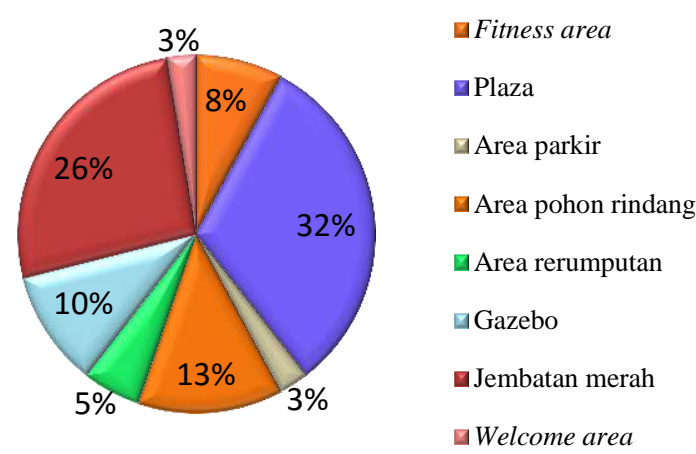

Gambar 27 Persentase persepsi responden tentang lokasi yang terasa hembusan angin di Taman Kota 2 BSD

Tanaman pada Taman Kota1 BSD berkategori baik dalam aspek penilaian fungsi penahan angin dengan skor sebesar 307,95 dan Taman Kota 2 BSD berkategori sedang dengan skor sebesar 300 (Tabel 20).

Tabel 20 Persentase penilaian tanaman fungsi penahan angin

\begin{tabular}{|c|c|c|c|c|c|c|c|}
\hline Lokasi & Kategori & $\begin{array}{c}\text { Jumlah } \\
\text { jenis }\end{array}$ & $\begin{array}{l}\text { Jumlah } \\
\text { individu }\end{array}$ & $\begin{array}{l}\text { Persentase } \\
\text { terhadap total } \\
\text { jenis }(\%)\end{array}$ & $\begin{array}{l}\text { Persentase } \\
\text { terhadap total } \\
\text { individu }(\%)\end{array}$ & $\begin{array}{l}\text { Skor } \\
\text { RTH }\end{array}$ & $\begin{array}{c}\text { Kategori } \\
\text { Skor } \\
\text { RTH }\end{array}$ \\
\hline & Buruk & 0 & 0 & 0 & 0.0 & & \\
\hline Taman & Sedang & 9 & 35 & 19.57 & 9.59 & & \\
\hline Kota 1 & Baik & 30 & 266 & 65.22 & 72.88 & 307.95 & Baik \\
\hline BSD & $\begin{array}{l}\text { Sangat } \\
\text { baik }\end{array}$ & 7 & 64 & 15.22 & 17.53 & & \\
\hline \multirow{4}{*}{$\begin{array}{l}\text { Taman } \\
\text { Kota } 2 \\
\text { BSD }\end{array}$} & Buruk & 0 & 0 & 0.0 & 0.0 & \multirow{4}{*}{300} & \multirow{4}{*}{ Sedang } \\
\hline & Sedang & 9 & 65 & 22.50 & 9.00 & & \\
\hline & Baik & 24 & 592 & 60.00 & 81.99 & & \\
\hline & $\begin{array}{l}\text { Sangat } \\
\text { baik }\end{array}$ & 7 & 65 & 17.50 & 9.00 & & \\
\hline
\end{tabular}

\section{Penilaian THI (Thermal Humidity Index)}

Kenyamanan thermal dapat dinilai juga dengan perhitungan menggunakan metode THI. Menurut beberapa penelitian indeks kenyamanan paling sesuai berada pada kisaran 20-27 (Mulyana, Laras, Budi 2003; Emmanuel 2005), 
sedangkan THI di dua lokasi penelitian melebihi rentang tersebut (Tabel 21). Hal ini diperkirakan karena pengukuran dilakukan ketika cuaca terik sehingga suhu udara tinggi saat siang hari dan sore hari. Namun terlihat perbedaan THI dalam taman lebih rendah dibandingkan dengan THI luar taman dengan selisih masingmasing taman sebesar 1,40 dan 1,17. Selisih tersebut menandakan kenyamanan thermal di dalam tapak masih lebih tinggi daripada di luar tapak.

Tabel 21 Penilaian THI di Taman Kota 1 BSD dan Taman Kota 2 BSD

\begin{tabular}{cccccccc}
\hline & \multicolumn{2}{c}{ Dalam RTH } & \multicolumn{2}{c}{ Luar RTH } & & & \\
\cline { 2 - 5 } Lokasi & T & RH & T & RH & THI & THI & \\
& $\begin{array}{c}\text { Rata- } \\
\text { rata }\end{array}$ & $\begin{array}{c}\text { Rata- } \\
\text { rata }\end{array}$ & $\begin{array}{c}\text { Rata- } \\
\text { rata }\end{array}$ & $\begin{array}{c}\text { Rata- } \\
\text { rata }\end{array}$ & $\begin{array}{c}\text { dalam } \\
\text { RTH }\end{array}$ & $\begin{array}{c}\text { luar } \\
\text { RTH }\end{array}$ & Selisih \\
& $\left({ }^{\circ} \mathrm{C}\right)$ & $(\%)$ & $\left({ }^{\circ} \mathrm{C}\right)$ & $(\%)$ & & & \\
\hline Taman Kota 1 BSD & 30.75 & 59.73 & 32.60 & 55.33 & 28.23 & 29.63 & 1.40 \\
Taman Kota 2 BSD & 29.88 & 68.52 & 31.79 & 59.56 & 27.96 & 29.13 & 1.17 \\
\hline
\end{tabular}

\section{Evaluasi Kualitas Estetika Lanskap}

\section{Evaluasi Estetika Taman Kota 1 BSD}

Survei yang dilakukan pada Taman Kota 1 BSD juga bertujuan untuk menentukan 20 titik yang akan menjadi vantage point pemotretan. Vantage point merupakan titik yang mewakili visual lanskap taman tersebut. Setelah menentukan vantage point, pemotretan dilakukan menggunakan kamera digital. Foto yang telah didapatkan kemudian dipresentasikan kepada responden untuk diberikan penilaian.

Hasil penilaian foto oleh responden dilakukan perhitungan menggunakan metode Scenic Beauty Estimation (SBE) dan kemudian dikelompokan menjadi estetika tinggi, sedang, dan rendah (Tabel 22).

Tabel 22 Penilaian kualitas estetika SBE Taman Kota 1 BSD

\begin{tabular}{crc}
\hline Foto lanskap ke- & Nilai SBE & Kualitas estetika \\
\hline 1 & 41,43 & Tinggi \\
2 & $-30,17$ & Rendah \\
3 & 65,96 & Tinggi \\
4 & 76,18 & Tinggi \\
5 & 0,00 & Sedang \\
6 & 3,02 & Sedang \\
7 & $-25,19$ & Rendah \\
8 & 58,22 & Tinggi \\
9 & 94,55 & Tinggi \\
10 & 18,35 & Sedang \\
11 & $-27,89$ & Rendah \\
12 & 41,89 & Tinggi \\
13 & 25,99 & Tinggi \\
14 & 37,23 & Tinggi \\
15 & 31,52 & Tinggi \\
16 & 71,48 & Tinggi \\
17 & 53,72 & Tinggi \\
18 & 81,31 & Tinggi \\
19 & 53,90 & Tinggi \\
20 & 49,01 & Tinggi \\
\hline
\end{tabular}


Foto lanskap yang memperoleh nilai SBE tertinggi yaitu foto lanskap ke-9 yang merupakan area jogging track dan nilai SBE terendah pada foto lanskap ke-2 yang merupakan area parkir (Gambar 28). Hasil penilaian responden menunjukkan bahwa 70\% pemandangan Taman Kota 1 BSD memperoleh nilai estetika tinggi (Gambar 29).

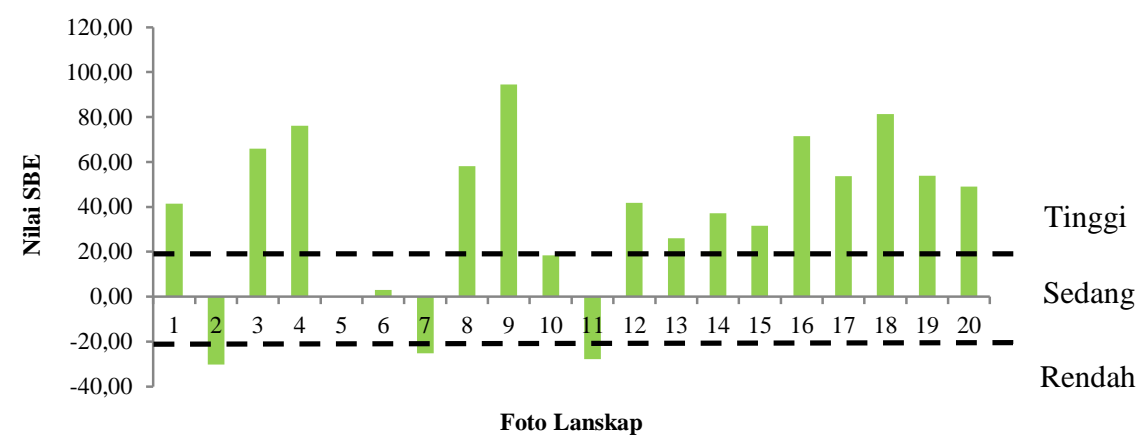

Gambar 28 Grafik nilai SBE Taman Kota 1 BSD

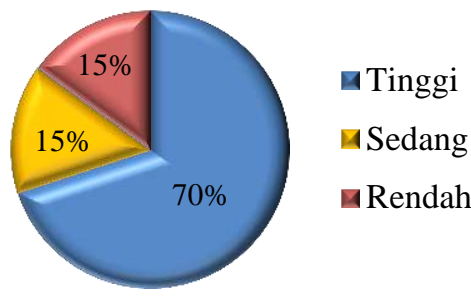

Gambar 29 Persentase kualitas estetika Taman Kota 1 BSD

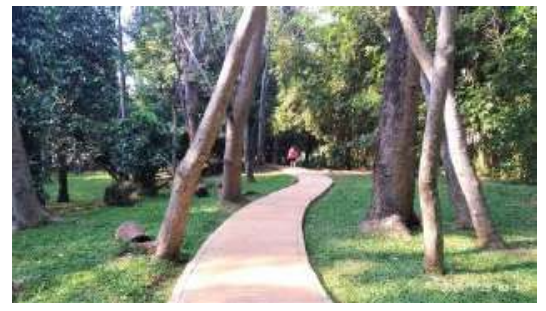

(a)

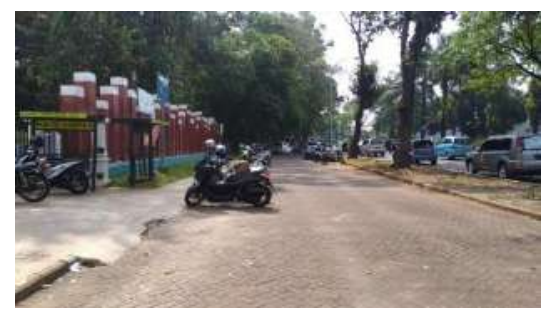

(b)

Gambar 30 (a) Foto Lanskap 9 (nilai SBE tertinggi) dan (b) Lanskap 2 (nilai SBE terendah) 


\section{Evaluasi Estetika Taman Kota 2 BSD}

Foto lanskap pada Taman Taman Kota 2 BSD yang dipresentasikan untuk penilaian sebanyak 40 buah yang mewakili seluruh area taman. Hasil penilaian foto oleh responden dilakukan perhitungan dan pengelompokkan juga (Tabel 23).

Tabel 23 Penilaian kualitas estetika SBE Taman Kota 2 BSD

\begin{tabular}{crc}
\hline Foto lanskap ke- & Nilai SBE & Kualitas estetika \\
\hline 1 & 40,17 & Tinggi \\
2 & 43,67 & Tinggi \\
3 & 61,28 & Tinggi \\
4 & 0,00 & Sedang \\
5 & 63,84 & Tinggi \\
6 & 77,39 & Tinggi \\
7 & 76,04 & Tinggi \\
8 & $-6,16$ & Sedang \\
9 & $-22,31$ & Rendah \\
10 & 24,83 & Tinggi \\
11 & 19,80 & Sedang \\
12 & 10,94 & Sedang \\
13 & $-22,67$ & Rendah \\
14 & $-4,01$ & Sedang \\
15 & $-18,00$ & Sedang \\
16 & $-36,35$ & Rendah \\
17 & $-17,39$ & Sedang \\
18 & 80,28 & Tinggi \\
19 & 88,63 & Tinggi \\
20 & 107,66 & Tinggi \\
21 & 57,84 & Tinggi \\
22 & $-14,80$ & Sedang \\
23 & $-38,94$ & Rendah \\
24 & $-5,24$ & Sedang \\
25 & 34,77 & Tinggi \\
26 & 0,45 & Sedang \\
27 & 76,22 & Tinggi \\
28 & 74,29 & Tinggi \\
29 & 71,39 & Tinggi \\
30 & 75,41 & Tinggi \\
31 & 59,31 & Tinggi \\
32 & 47,37 & Tinggi \\
33 & 89,03 & Tinggi \\
34 & 55,68 & Tinggi \\
35 & 32,04 & Tinggi \\
36 & 25,47 & Tinggi \\
37 & 12,83 & Sedang \\
38 & & Tinggi \\
39 & Rendah \\
40 & Tinggi \\
\hline & \\
\hline
\end{tabular}


Foto lanskap yang memperoleh nilai SBE tertinggi yaitu foto lanskap ke-20 yang merupakan pemandangan di area sungai dan nilai terendah pada foto lanskap ke-39 yang merupakan area pedagang di taman tersebut (Gambar 31). Hasil penilaian responden menunjukkan bahwa $60 \%$ pemandangan Taman Kota 2 BSD memperoleh nilai estetika tinggi (Gambar 32).

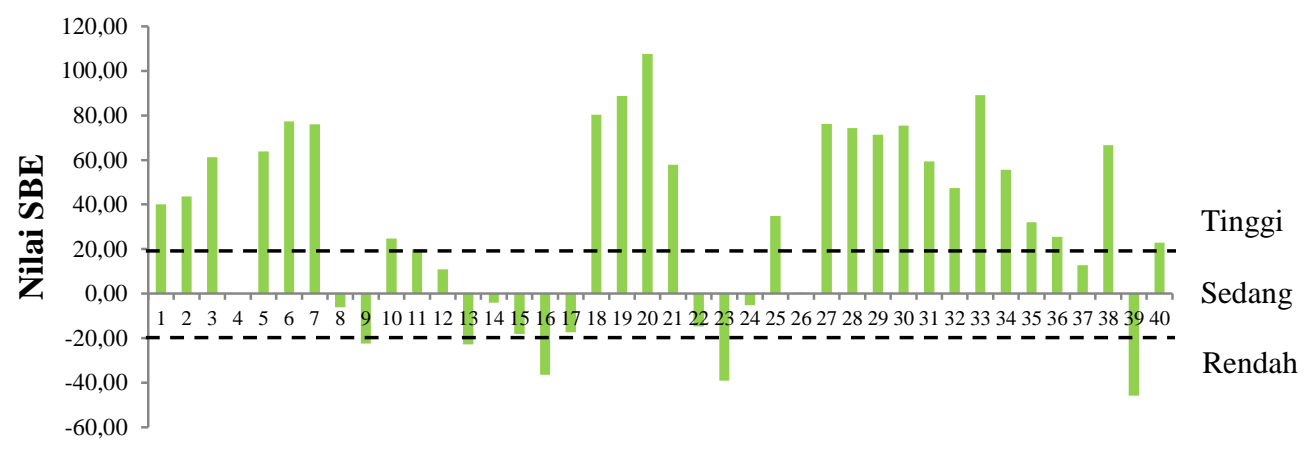

Foto Lanskap

Gambar 32 Grafik nilai SBE Taman Kota 2 BSD

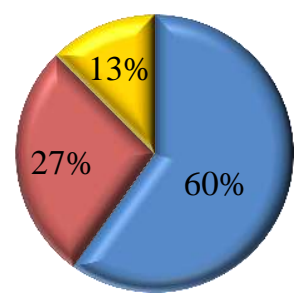

国Tinggi

国 Sedang

aRendah

Gambar 33 Persentase kualitas estetika Taman Kota 2 BSD

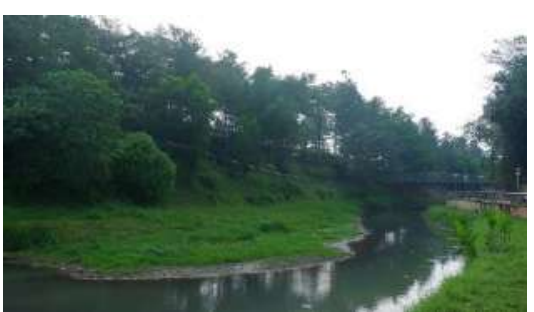

(a)

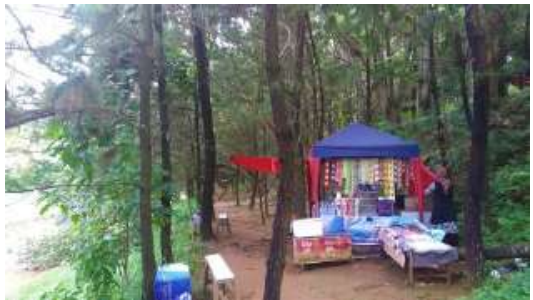

(b)

Gambar 34 (a) Foto Lanskap ke-20 (nilai SBE tertinggi) dan

(b) Lanskap 39 (nilai SBE terendah) 


$$
1
$$




\section{Persepsi dan Preferensi Responden}

Persepsi dan preferensi responden diambil menggunakan kuesioner kepada 80 orang pengunjung yang diambil dari masing-masing taman kota sebanyak 40 orang. Data yang didapatkan terdiri dari kararteristik responden, persepsi, serta preferensi responden mengenai kenyamanan dan estetika taman kota yang dikunjungi. Data persepsi responden diharapkan dapat memberikan informasi mengenai kondisi yang dirasakan oleh pengunjung dan data preferensi dapat mewakili preferensi pengunjung secara keseluruhan terhadap taman tersebut.

\section{Karakteristik responden}

Data karakteristik responden memberikan informasi mengenai karakteristik pengunjung pada masing-masing taman kota secara keseluruhan. Karakteristik responden juga berpengaruh terhadap pengetahuan responden mengenai fungsi taman kota dan preferensinya terhadap taman tersebut. Data yang ditanyakan antara lain jenis kelamin, usia, pekerjaan, pendidikan terakhir, dan tujuan kunjungan.

Hasil dari pengambilan data kuisioner, sebagian besar responden di masingmasing taman merupakan perempuan (Gambar 34). Responden dari kedua taman didominasi oleh responden berusia 21-23 tahun (Gambar 35).

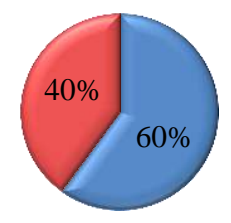

(a)

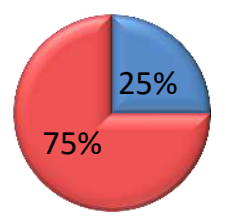

(b)
口Laki-laki

回Perempuan

Gambar 36 Persentase jenis kelamin responden (a) Taman Kota 1 BSD dan (b) Taman Kota 2 BSD

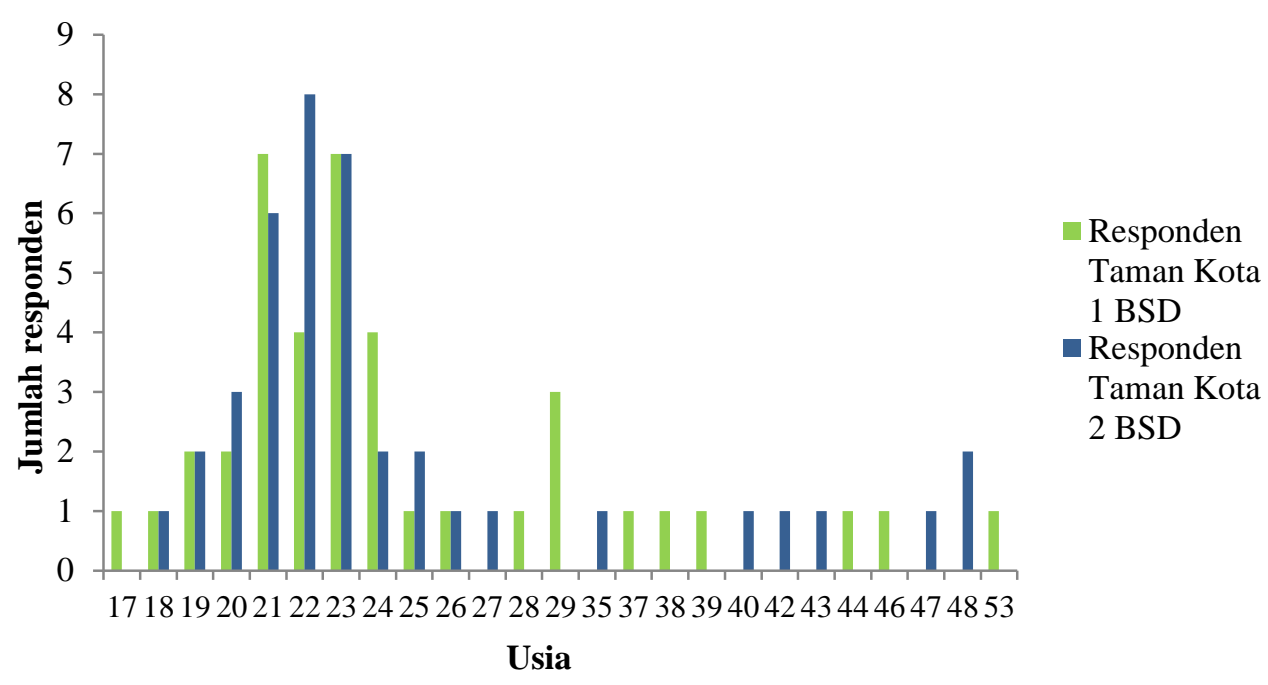

Gambar 37 Persentase usia responden (a) Taman Kota 1 BSD dan (b) Taman Kota 2 BSD 
Latar belakang pendidikan terakhir responden Taman Kota 1 BSD sebanyak 47\% tingkat sarjana, kemudian tingkat SMA yang tidak berbeda jauh yaitu sebanyak 45\% (Gambar 36). Responden Taman Kota 2 BSD didominasi dengan latar belakang pendidikan terakhir di tingkat SMA yaitu sebanyak 70\% (Gambar 36). Persentase pekerjaan responden kedua taman paling banyak merupakan mahasiswa (Gambar 37).

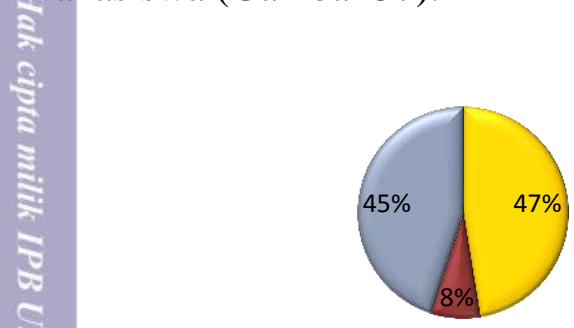

(a)

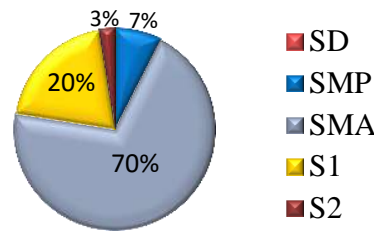

(b)

Gambar 38 Persentase pendidikan terakhir responden (a) Taman Kota 1 BSD dan (b) Taman Kota 2 BSD

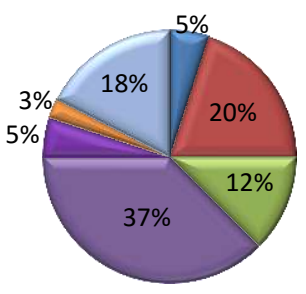

(a)

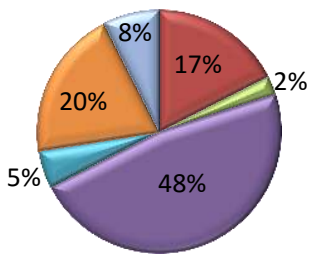

(b)

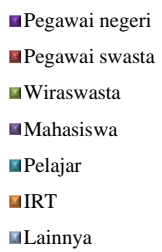

gLainnya

Gambar 39 Persentase pekerjaan responden (a) Taman Kota 1 BSD dan (b) Taman Kota 2 BSD

Responden yang datang ke Taman Kota 1 BSD sebanyak 50\% responden memiliki tujuan berolahraga, selanjutnya sebanyak $45 \%$ responden bertujuan rekreasi, $2 \%$ bertujuan edukasi, dan 3\% memiliki tujuan lainnya. Responden Taman Kota 2 BSD sebanyak 55\% memiliki tujuan rekreasi, 27\% bertujuan olahraga, $2 \%$ edukasi, dan ada juga responden yang berkunjung karena ingin tahu (Gambar 38).

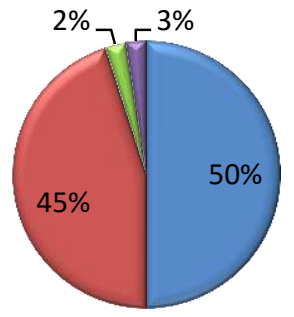

(a)

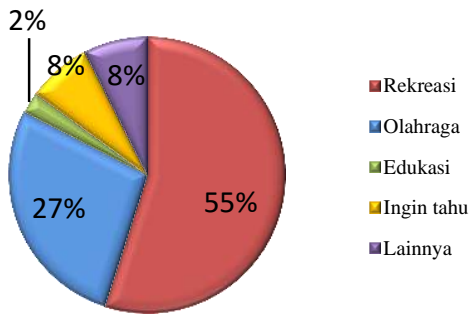

(b)

Gambar 40 Persentase tujuan responden berkunjung ke (a) Taman Kota 1 BSD dan (b) Taman Kota 2 BSD 


\section{Persepsi responden}

Persepsi responden yang diperlukan dalam penelitian ini yaitu mencakup persepsi mengenai kenyamanan, keindahan, kebersihan, dan kepuasan di masingmasing taman kota. Persepsi responden mewakili penilaian pengunjung secara umum terhadap masing-masing taman tersebut.

Persepsi responden mengenai kenyamanan dilihat dari kesejukan, kelembaban, dan kecepatan angin. Persepsi kenyaman tersebut sudah dibahas dalam pembahasan sebelumnya mengenai penilaian aspek fungsi modifikasi suhu, kontrol udara, dan penahan angin. Hasilnya menunjukkan persepsi responden sebanding juga dengan hasil penilaian fungsi ekologis tanaman di masing-masing taman atau pun hasil pengukuran. Area pohon rindang merupakan lokasi yang sejuk, kelembaban sedang, dan terdapat hembusan angin sehingga menjadi lokasi yang disenangi oleh pengunjung.

Persepsi keindahan didapatkan dengan penilaian terhadap keindahan pemandangan, keindahan penataan tanaman dan kebersihan. Ketiga aspek tersebut mempengaruhi persepsi pengunjung terhadap kualitas estetika lanskap. Sebagian besar responden menilai Taman Kota 1 BSD dan Taman Kota 2 BSD memiliki pemandangan yang indah dengan persentase di kedua taman tersebut sama yaitu 60\% (Gambar 39). Responden yang menilai penataan tanaman di kedua taman indah juga tidak berbeda jauh yaitu persentase masing-masing sebesar $55 \%$ dan 57\% (Gambar 40).

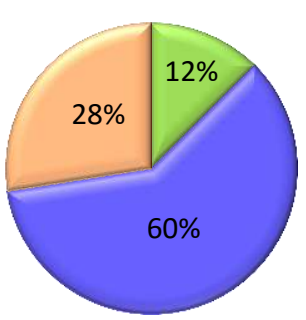

(a)

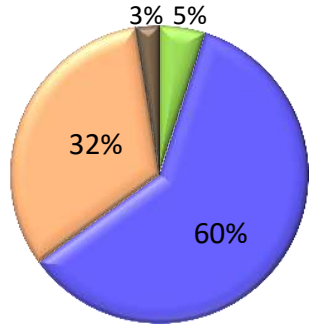

(b)

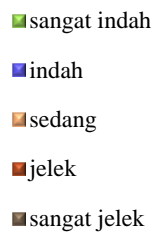

四angat jelek

Gambar 41 Persepsi responden terhadap keindahan pemandangan (a) Taman Kota 1 BSD dan (b) Taman Kota 2 BSD

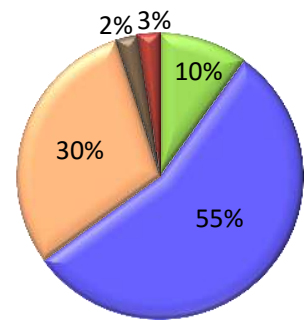

(a)

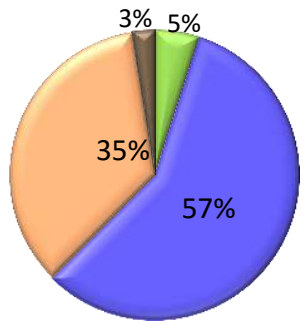

(b)

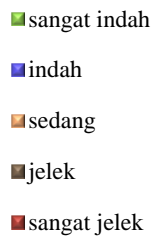

Gambar 42 Persepsi responden terhadap keindahan penataan tanaman di (a) Taman Kota 1 BSD dan (b) Taman Kota 2 BSD

Penilaian aspek kebersihan Taman Kota 1 BSD terdapat 7\% responden yang menilai taman tersebut sangat bersih, sedangkan responden yang menilai taman tersebut berada pada tingkat bersih dan sedang hampir setara yaitu $42 \%$ dan $45 \%$ 
(Gambar 41). Persepsi responden terhadap kebersihan Taman Kota 2 hanya 2\% atau 1 orang yang menilai sangat bersih, kemudian $45 \%$ responden menilai bersih,

$35 \%$ menilai sedang, dan $18 \%$ menilai kotor.

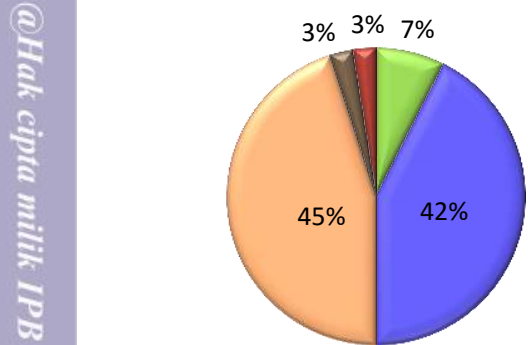

(a)

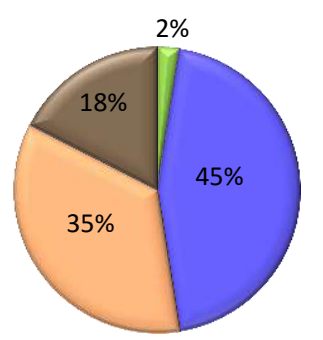

(b) $\square$ sangat bersih

口bersih

$\square$ sedang

口 kotor

घangat kotor

Gambar 43 Persepsi responden terhadap kebersihan di (a) Taman Kota 1 BSD dan (b) Taman Kota 2 BSD

Berdasarkan persepsi kepuasan responden terhadap kondisi Taman Kota 1 BSD dan Taman Kota 2 BSD, sebagian besar responden di kedua taman tersebut menyatakan merasa puas (Gambar 42). Persentase responden Taman Kota 1 BSD yang menyatakan merasa puas sebanyak $43 \%$ dan terdapat $20 \%$ yang merasa sangat puas. Taman Kota 2 BSD sebanyak $62 \%$ respondennya merasa puas dengan kondisi taman tersebut.

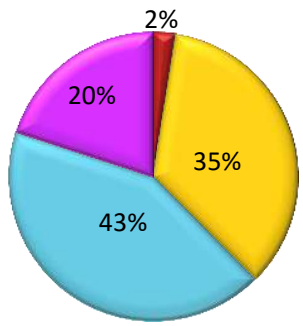

(a)

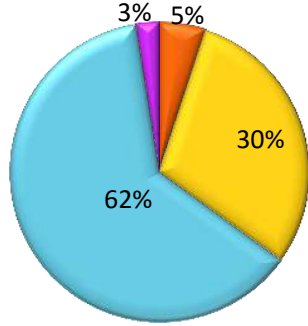

(b)

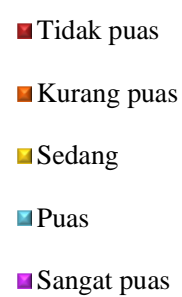

Q Sangat puas

Gambar 44 Persepsi kepuasan terhadap (a) Taman Kota 1 BSD dan (b) Taman Kota 2 BSD

\section{Preferensi responden}

Preferensi responden diambil dengan menyajikan pertanyaan terkait pilihan area yang dinilai indah oleh responden dan saran untuk pengembangan taman agar estetika dan kenyamanannya lebih optimal. Responden Taman Kota 1 BSD sebanyak 32\% memilih jogging track sebagai area yang memiliki pemandangan indah, 27\% memilih welcome area, dan 20\% memilih area pohon rindang. Responden Taman Kota 2 BSD sebanyak 32\% memilih area plaza yang memiliki pemandangan indah, $30 \%$ memilih area pohon rindang, dan $15 \%$ memilih jembatan merah.

Responden kedua taman juga memberikan preferensi terhadap tanaman yang ada di masing-masing taman. Responden sebagian besar menginginkan 
adanya tambahan tanaman berbunga dan berstrata untuk menambah nilai keindahan di taman tersebut.

Responden Taman Kota 1 BSD beberapa juga menginginkan penambahan fasilitas seperti toilet, children playground, dan tempat sampah. Jumlah toilet yang tersedia memang masih satu buah sehingga terkadang akan terjadi antrian ketika jumlah pengunjung cukup banyak. Ada juga responden yang menyarankan untuk diadakan papan nama jenis setiap tanaman yang ada di taman tersebut agar bisa sebagai edukasi oleh pengunjung.

Responden Taman Kota 2 BSD sebagian besar menyarankan agar ada tambahan jumlah fasilitas toilet karena di taman bagian depan belum tersedia toilet dan cukup jauh jika harus menuju toilet yang ada di taman bagian belakang. Ada juga saran untuk memasangkan papan nama jenis tanaman untuk media edukasi pengunjung. Responden juga menyarankan adanya perbaikan fasilitas yang sudah mulai terjadi kerusakan seperti jogging track yang mengalami retakan.Kemudian ada saran dari pengunjung yang merupakan pemain skateboard agar dilakukan perbaikan arena skate park karena bentuk dan ukuran rintangan pada arena tidak sesuai dan justru dapat mengakibatkan kecelakaan bagi penggunanya.

\section{Rekomendasi}

Berdasarkan analisis hasil pengukuran serta persepsi dan preferensi responden dihasilkan rekomendasi penataan tata hijau untuk meningkatkan kenyamanan dan estetika pada Taman Kota 1 BSD dan Taman Kota 2 BSD. Tata hijau yang direkomendasikan yaitu dengan menambahan tanaman berbunga dan berstrata sehingga menghadirkan nilai estetika.

Rekomendasi pertama yaitu penambahan tanaman pada bagian pepohonan di sekitar jogging track dan sitting area yang merupakan lokasi sering di kunjungi (Gambar 43 dan 44). Penambahan tanaman berbunga yaitu Lantana camara. Selain tanaman berbunga ditambahkan juga tanaman groundcover yaitu Axonopus compressus, Chlorophytum comosum, dan Bromelia sp. . Tanaman tersebut direkomendasikan karena cocok tumbuh di bawah naungan.

Rekomendasi perbaikan fasilitas juga diberikan yaitu perbaikan pada jogging track dan sitting area yang telah rusak. Perbaikan tidak merubah bentukan awal, hanya dilakukan pengecoran dan pengecatan ulang agar terlihat lebih indah dan memberikan kenyamanan.

(a)

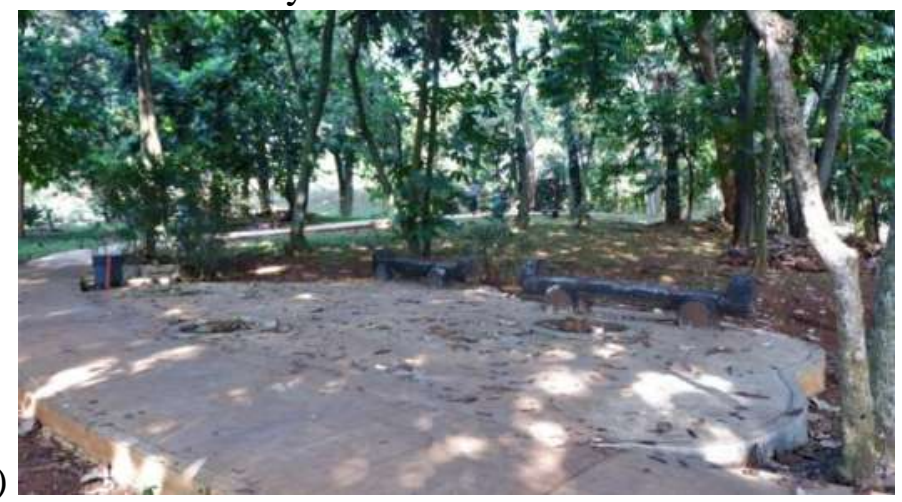


(b)

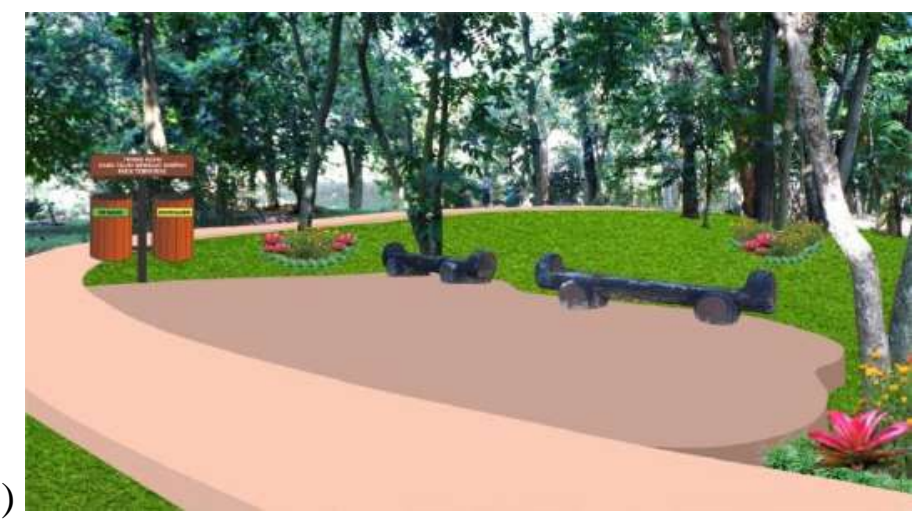

Gambar 45 Ilustrasi penataan tanaman Taman Kota 1 BSD (a) kondisi eksisting dan (b) hasil rekomendasi

(a)

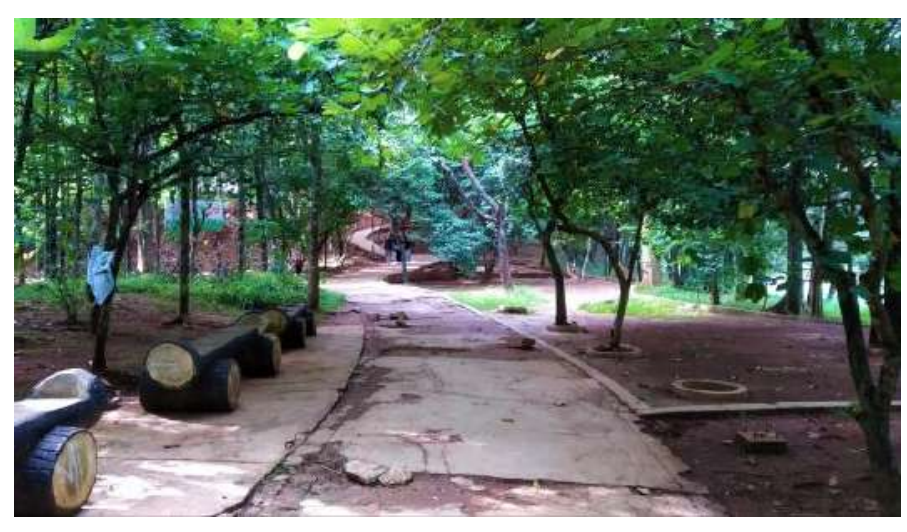

(b)

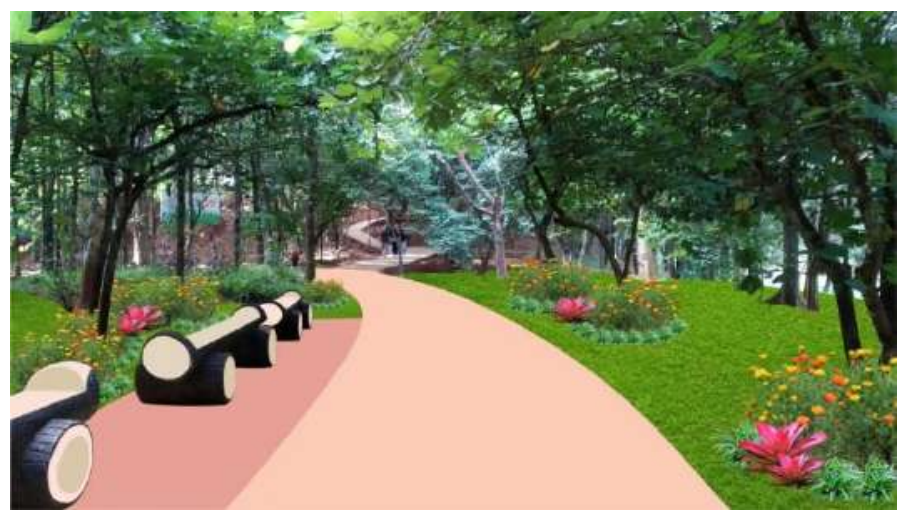

Gambar 46 Ilustrasi penataan tanaman Taman Kota 2 BSD (a) kondisi eksisting dan (b) hasil rekomendasi

Rekomendasi berikutnya yaitu penambahan tanaman merambat pada area mushala. Beberapa pengunjung menyarankan agar diberikan penghalang untuk bagian tempat wudhu wanita di mushala. Penambahan tanaman merambat ini bertujuan untuk menjadi penghalang tempat wudhu wanita agar memberikan kenyamanan kepada pengunjung wanita yang hendak berwudhu (Gambar 45 dan 46). Tanaman yang pilih adalah tanaman merambat yang mampu tumbuh di 
bawah naungan karena lokasi mushala yang juga rindang oleh pepohonan. Tanaman yang direkomendasikan yaitu Passiflora sp. .

(a)

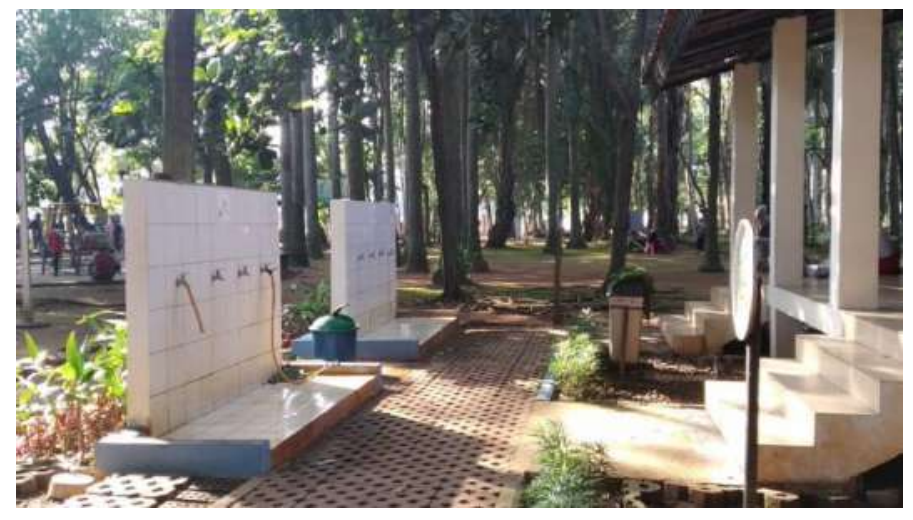

(b)

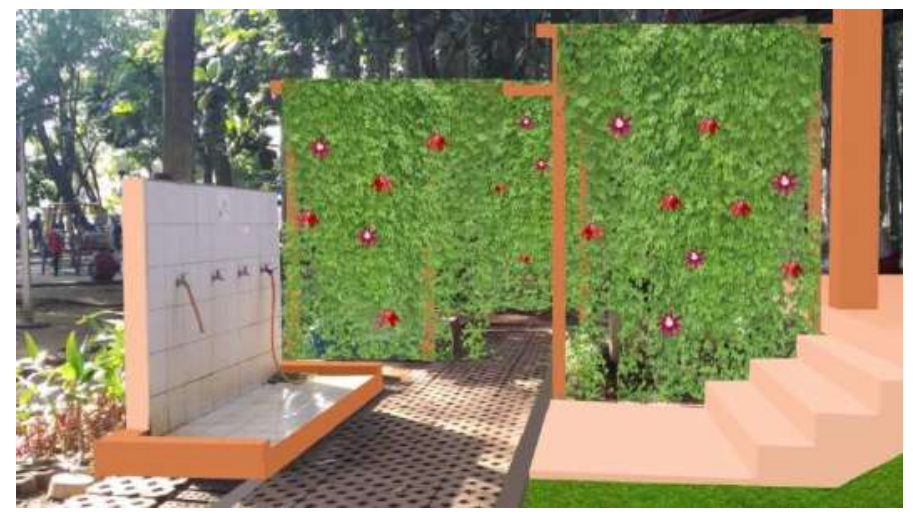

Gambar 47 Ilustrasi penambahan tanaman merambat pada tempat wudhu Mushala Taman Kota 1 BSD (a) kondisi eksisting dan (b) hasil rekomendasi

(a)

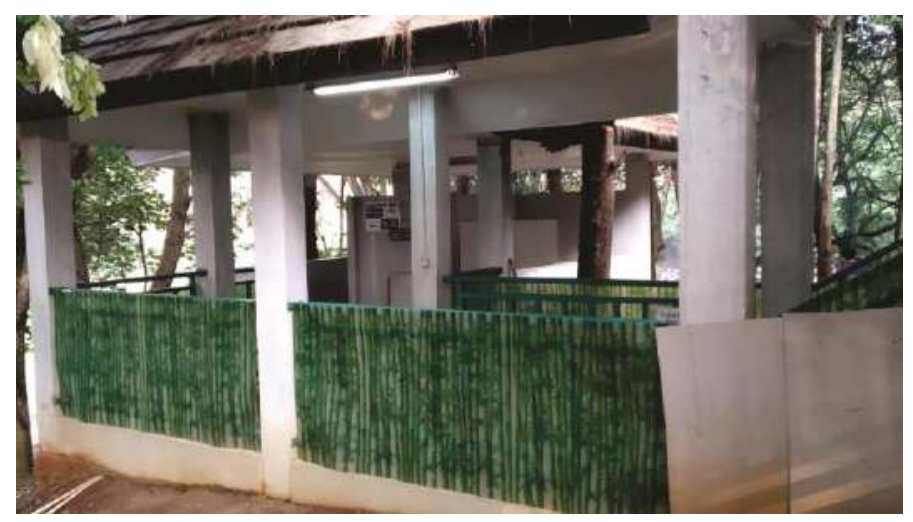


(b)

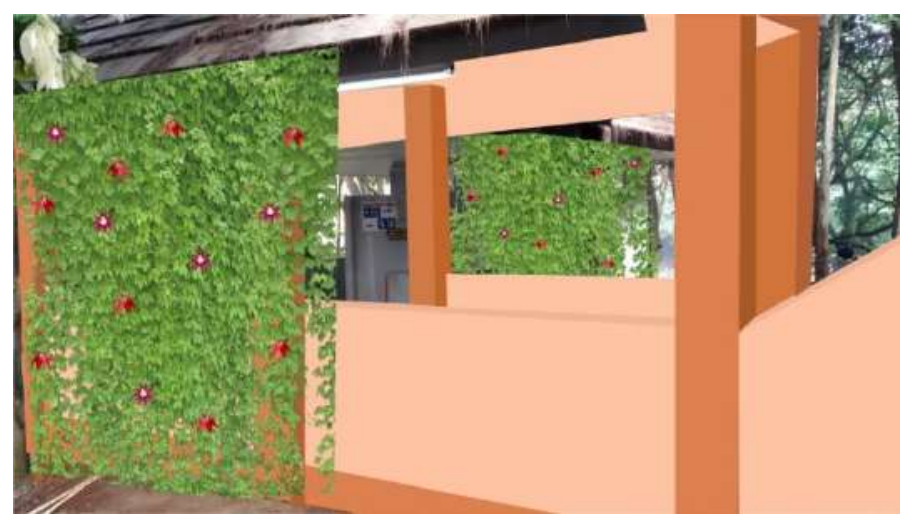

Gambar 48 Ilustrasi penambahan tanaman merambat pada tempat wudhu Mushala Taman Kota 2 BSD (a) kondisi eksisting dan (b) hasil rekomendasi

Rekomendasi selanjutnya yaitu pada gerbang masuk Taman Kota 2 BSD yang telah mengalami kerusakan padahal lokasi ini berpengaruh dengan ketertarikan pengunjung. Rekomendasi berupa perbaikan signage dan gerbang, serta penambahan tanaman (Gamba 47). Tanaman yang digunakan yaitu Furcraea gigantea, Lantana camara, Rhoeo discolor, Chlorophytum comosum, dan Bromelia sp. .

(a)

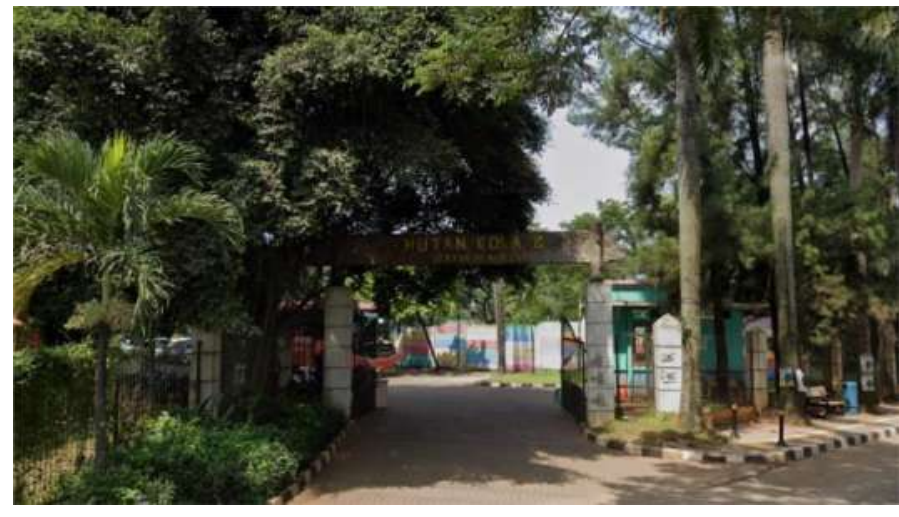

(b)

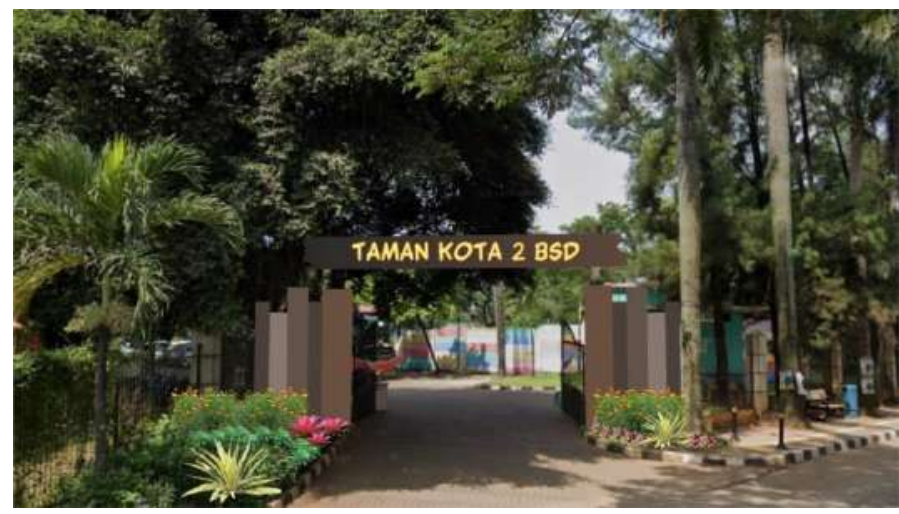

Gambar 49 Ilustrasi perbaikan dan penataan pada gerbang Taman Kota 2 BSD

(a) kondisi eksisting dan (b) hasil rekomendasi 
Selain penataan tanaman, responden juga memberikan saran agar adanya pemasangan papan nama tanaman untuk edukasi kepada pengunjung kedua taman tersebut. Oleh karena itu, diberikan rekomendasi pemasangan papan nama tanaman. Papan dibuat dengan ukuran $25 \mathrm{~cm}$ x $15 \mathrm{~cm}$ bermaterial lempengan besi dan dililitkan dengan kawat spiral pada batang pohon sehingga tidak mengganggu pertumbuhan pohon tersebut (Gambar 48).

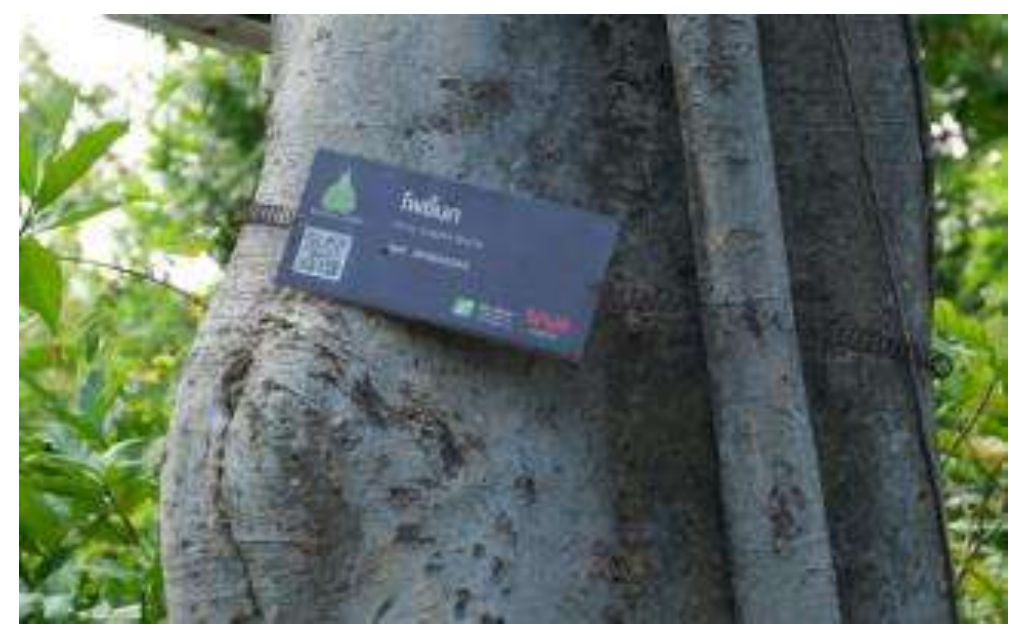

Gambar 50 Contoh pemasangan papan nama tanaman

\section{SIMPULAN DAN SARAN}

\section{Simpulan}

Kawasan BSD City memiliki dua taman kota yaitu Taman Kota 1 BSD dan Taman Kota 2 BSD. Kedua taman tersebut memiliki tanaman yang beragam jenis dan fungsinya. Total pohon di Taman Kota 1 BSD sebanyak 365 pohon yang terdiri dari 46 spesies. Pohon di Taman Kota 2 BSD terdiri dari 40 spesies dengan 722 total individu.

Hasil penilaian tanaman menunjukkan bahwa kedua taman tersebut memiliki kategori baik berdasarkan fungsi ekologis tanaman dalam memodifikasi suhu udara. Hasil pengukuran suhu udara juga menunjukkan adanya penurunan suhu rata-rata. Taman Kota 1 BSD menurunkan suhu rata-rata dibandingkan pada luar taman dengan selisih $1,8^{\circ} \mathrm{C}$, sedangkan Taman Kota 2 BSD menurunkan suhu rata-rata dengan selisih $1,90^{\circ} \mathrm{C}$. Kedua taman juga termasuk dalam kategori baik berdasarkan penilaian fungsi tanaman dalam kontrol kelembaban. Berdasarkan pengukuran juga terlihat adanya peninggkatan kelembaban. Taman Kota 1 BSD menaikkan kelembaban rata-rata dengan selisih 4,40\% dan Taman Kota 2 menaikkan kelembaban rata-rata sebesar 8,96\%. Taman Kota 1 BSD masuk kategori baik dalam penilaian fungsi tanaman dalam menahan angin, sedangkan Taman Kota 2 BSD berkategori sedang.

Tanaman Palem raja Roystonea regia) yang merupakan tanaman dominasi di Taman Kota 1 BSD dan Pinus (Pinus Merkusii) yang merupakan tanaman dominasi di Taman Kota 2 BSD juga termasuk kategori baik dalam fungsi 
ameliorasi iklim mikro. Bahkan Pinus (Pinus merkusii) berkategori sangat baik dalam fungsi kontrol kelembaban.

Hasil evaluasi kualitas estetika lanskap menunjukkan persentase lanskap bernilai estetika tinggi pada Taman Kota 1 BSD lebih besar dibandingkan Taman Kota 2 BSD. Lanskap dengan nilai SBE tertinggi di Taman Kota 1 BSD yaitu pada jogging track, sedangkan yang terendah yaitu pada area parkir. Lanskap dengan nilai SBE tertinggi di Taman Kota 2 BSD yaitu pada pemandangan sungai, sedangkan yang memiliki nilai SBE terendah yaitu pada area pedagang.

Berdasarkan hasil perhitungan menunjunjukkan bahwa kedua taman masih belum ideal dalam indeks kenyamanan THI karena nilai THI melebihi 27. Akan tetapi, penilaian responden mayoritas menyatakan nyaman berada di lingkungan kedua taman. Responden mayoritas merasa nyaman ketika di area pohon rindang dan berdasarkan penilaian SBE juga menunjukkan area pohon rindang memiliki nilai kategori estetika tinggi. Kenyamanan selain dipengaruhi oleh iklim mikro juga dipengaruhi dari aspek estetika yang dinikmati oleh pengguna suatu tapak.

Rekomendasi dibuat untuk masing-masing taman berdasarkan dari hasil analisis penilaian, pengukuran, dan persepsi serta preferensi responden. Rekomendasi berupa penambahan dan penataan tanaman. Tanaman yang dipilih didominasi dengan yang memiliki fungsi estetika, sebab sebagian besar responden menginginkan adanya tambahan tanaman yang lebih berwarna seperti tanaman berbunga. Rekomendasi perbaikan fasilitas juga dibuat untuk meningkatkan kenyamanan pengunjung seperti perbaikan pada jogging track, tempat duduk, dan gerbang masuk, serta dibuatkannya penutup tempat wudhu dengan tanaman merambat.

\section{Saran}

Penelitian ini diharapkan dapat diaplikasikan sebagai rekomendasi untuk perbaikan Taman Kota 1 BSD dan Taman Kota 2 BSD selanjutnya agar lebih memperhatikan aspek kenyamanan pengunjung dan aspek estetika. Penggunaan tanaman diharapkan dapat menyesuaikan dengan fungsi yang dibutuhkan agar kondisi ekologis dan estetika lebih optimal. Standarisasi dalam pembuatan fasilitas juga perlu diperhatikan agar memberikan kenyamanan kepada pengguna.

\section{DAFTAR PUSTAKA}

Abello RP, Bernaldez FG. 1986. Landscape Preference amd Personality. Landscape and Urban Planning, 13:19-28.

Alhadi MR. 2016. Analisis kepuasan pengunjung terhadap fungsi rekreasi Taman Kota 2 Bumi Serpong Damai City di Kota Tangerang Selatan. [skripsi]. Bandung (ID): Universitas Pendidikan Indonesia.

Arifin HS, Munandar A, Arifin NHS, Pramukanto Q, Damayanti VD. 2008. Sampoerna Hijau Kotaku Hijau. Bogor: Sampoerna Hijau.

Bianpoen et al. 1989. Fungsi Taman dalam Kota (naskah laporan). Jakarta (ID): Pusat Penelitian Teknologi dan Pemukiman Universitas Tarumanegara.

Carpenter PL., TD. Walker dan FO. Lamphear. 1975. Plants in The Landscape. San Fransisco: W.H Freeman and Co. 
Dahlan EN. 1992. Membangun Kota Kebun (Garden City) Bernuansa Taman Kota 2. Bogor (ID): IPB Press.

Daniel TC dan Booster RS.1976. Measuring Landscape Aesthetics: the Scenic Beauty Estimation Methode. USDA Forest Service Research Paper. RM167.

Departemen Pekerjaan Umum. 1996. Tata Cara Perencanaan Teknik Lanskap Jalan. Direktorat Jenderal Bina Marga. Jakarta (ID): Departemen Pekerjaan Umum.

Departemen Pekerjaan Umum. 2008. Peraturan Menteri Pekerjaan Umum Nomor:05/PRT/M/2008 tentang Pedoman Penyediaan dan Pemanfaatan Ruang Terbuka Hijau di Kawasan Perkotaan. Jakarta (ID): Direktorat Jenderal Penataan Ruang.

Direktorat Jenderal Bina Marga. 2010. Pedoman Teknis Penanaman Pohon pada Sistem Jaringan Jalan. Jakarta: Departemen Pekerjaan Umum.

Eckbo G. 1964. Urban Landscape Design. New York (US): Mc.Graw-Hill Book Co. 248p.

Effendi S, A Bey, AFM. Zain, I Santosa. 2006. Peranan ruang terbuka hijau dalam mengendalikan suhu udara dan urban heat island wilayah Jabotabek. Agromet Indonesia. 20 (01): 23-33.

Emmanuel R. 2005. Thermal comfort implication of urbanization in a warm humid city : the Colombo Metropolitan Region (CMR). Build and Environ. $40: 1591-1601$.

Fathonah IN. 2018. Kajian fungsi ekologis dan estetika beberapa ruang terbuka hijau publik di Kota Tasikmalaya. [skripsi]. Bogor (ID): Institut Pertanian Bogor.

Femy. 2014. Perencanaan tata hijau untuk kenyamanan klimatologis pada balai besar pengembangan mekanisasi pertanian. [tesis]. Bogor (ID): Sekolah Pasca Sarjana Institut Pertanian Bogor.

Grey GW dan FJ Daneke. 1978. Urban Forestry. New York (US): John Willey and Sons inc.

Heath TF. 1988. Behavioral and Perceptual Aspects of The Aesthetics of Urban Environments. New York (US): Cambridge Univ Pr. hlm. 6-10.

Hidayat AMA. 2010. Studi evaluasi taman kota sebagai Taman Terapeutik (studi kasus: Taman Cilaki Atas, Kota Bandung) [skripsi]. Bogor (ID): Institut Pertanian Bogor.

Hidayat IW.2008. Evaluasi jalur hijau jalan sebagai penyangga lingkungan sekitarnya dan keselamatan pengguna jalan bebas hambatan Jagorawi. [thesis]. Bogor (ID): Institut Pertanian Bogor.

Imansari N dan Khadiyanta P. 2015. Penyediaan hutan kota dan taman kota sebagai Ruang Terbuka Hijau (RTH) publik menurut preferensi masyarakat di kawasan pusat Kota Tangerang. 1(3): 102

Kustianingrum, D; Angga Kusumah Sukarya; Rifan Athariq Nugraha; Franderdi Rachadi Tyagarga. 2013. Fungsi dan Aktifitas Taman Ganesha sebagai Ruang Publik di Kota Bandung. Jurnal Reka Karsa. 1(2): 2.

Hidayat IW. 2009. Uji scenic beauty estimation terhadap konfigurasi tegakantegakan vegetasi di Kebun Raya Bogor. Prosiding SN SMAP. 09. 
Kaplan S. 1988. Perception and Landscape: Conception and Misconceptions. In Jack LN. Editor. Enviromental Aesthetics. New York (US): Cambridge Univ. Pr. p 44-45.

Laurie, M. 1986. An Introduction to Landscape Architecture. New York: American Elsevier Publ. Co. Inc.

Lippsmeier G. 1994. Bangunan Tropis. Syahmir Nasution, penerjemah. Jakarta (ID): Erlangga. Terjemahan dari: Tropenbau Building in the Tropics

Mahardi F. 2013. Evaluasi fungsi ekologis dan estetika pada beberapa taman kota di Jakarta. [skripsi]. Bogor (ID): Institut Pertanian Bogor.

Mulyana M, Laras T, Budi SH. 2003. Impact of urban Development on the Climate and Environment. Bandung (ID): ITB Press.

Nassar JL. 1988. Environmental Aesthetic. New York (US): Cambridge Univ Pr. $529 \mathrm{p}$.

Pratama GE. 2013. Rencana pengembangan ruang terbuka hijau berdasarkan distribusi suhu permukaan dan temperature humidity index (THI) di Kota Surakarta. [skripsi]. Bogor (ID): Institut Pertanian Bogor.

Simonds JO. 1983. Landscape Architecture. New York: Mc Graw - Hill Book Co.

Uma H. 2015. Persepsi: pengertian, definisi, dan faktor yang mempengaruhi. Kompasiana. [Internet]. (2015 Jun 24 [diunduh 2017 Okt 20]). Tersedia pada:https://www.kompasiana.com/hasminee/persepsi-pengertian-definisidan-factor-yang-mempengaruhi_552999136ea8349a1f552d01.

Wibisono Y. 2008. Pengelolaan Lanskap dan Pemeliharaan Taman Kota 1 di BSD City, Tangerang Selatan. [skripsi]. Bogor (ID): Institut Pertanian Bogor. 


\section{RIWAYAT HIDUP}

Penulis bernama Rani Isnaniyah kelahiran Jakarta pada 23 Desember 1998 sebagai anak kedua dari dua bersaudara dari (Alm) Bapak Riyadi dan Ibu Siti Nuryani. Penulis menempuh pendidikan sekolah menengah atas di SMA Negeri 24 Jakarta dan lulus pada tahun 2016. Penulis kemudian melanjutkan pendidikan sarjana di Institut Pertanian Bogor pada program studi Arsitektur Lanskap.

Penulis aktif dibeberapa kegiatan kemahasiswaan sejak tahun pertama perkuliahan. Penulis aktif dalam organisasi Dewan Mushola Asrama IPB sebagai anggota divisi syiar. Selanjutnya penulis aktif dalam organisasi Forum Komunikasi Rohis Departemen (FKRD) Fakultas Pertanian sebagai sekretaris divisi Komunikasi dan Informasi pada periode tahun 2017/2018 serta menjabat Sebagai Mas'ulah (koordinator akhwat) FKRD pada periode tahun 2018/2019. Selain organisasi, penulis juga aktif dalam beberapa kepanitiaan yaitu Masa Pengenalan Kampus Mahasiswa Baru (MPKMB) IPB 54, Salam Al Hurriyyah 1439 H, International Landscape Architecture Student Workshop (ILASW) 2018, dan Saung Tani FAPERTA 2018.

Penulis memiliki pengalaman menjadi asisten mata kuliah Pendidikan Agama Islam pada semester ganjil periode tahun 2019/2020. Penulis juga memiliki karya sebuah tulisan berjudul "Wujud Cinta dari-Nya" yang diterbitkan pada tahun 2019 dalam buku antalogi berjudul "Jangan Menyerah saat Ada Masalah" melalui project nulis buku bareng Robi Afrizan Putra batch 16. 